Katbleen Daly and Brigitte Boubours

\title{
Rape and Attrition in the Legal Process: A Comparative Analysis of Five Countries
}

\begin{abstract}
Despite legal reforms, there has been little improvement in police, prosecutor, and court handling of rape and sexual assault. In the past 15 years in Australia, Canada, England and Wales, Scotland, and the United States, victimization surveys show that 14 percent of sexual violence victims report the offense to the police. Of these, 30 percent proceed to prosecution, 20 percent are adjudicated in court, 12.5 percent are convicted of any sexual offense, and 6.5 percent are convicted of the original offense charged. In the past 35 years, average conviction rates have declined from 18 percent to 12.5 percent, although they have not fallen in all countries. Significant country differences are evident in how cases are handled and where in the legal process attrition is most likely. There is some good news: a victim's "good" character and credibility and stranger relations are less important than they once were in police or court outcomes. However, evidence of nonconsent (witness evidence, physical injuries to the victim, suspect's use of a weapon) continues to be important.
\end{abstract}

In 1978, the first studies written in English of police and court responses to rape were published. As of September 2007, over 90 attrition studies had reported findings for Australia, Canada, England and

Kathleen Daly is professor of criminology and criminal justice at Griffith University (Brisbane). Brigitte Bouhours is research officer in the Centre of Excellence in Policing and Security, Australian National University (Canberra), formerly, senior research assistant, Griffith University, working with Daly for 9 years to October 2009. We are grateful to Michael Tonry and the reviewers for their extended and helpful comments on an earlier draft.

(C) 2010 by The University of Chicago. All rights reserved.

0192-3234/2010/0039-0009\$10.00 
Wales, Scotland, and the United States from 1970 to $2005 .{ }^{1}$ Some analyze the same data set, and the findings from others can be combined; thus, the unique set of cases reduces to 75 . In this essay, we analyze this body of research from five countries ${ }^{2}$ to identify patterns in police, prosecutor, and court handling of rape and sexual assault cases. It is contextualized by victimization surveys, police statistics, and court data from the countries examined. We also explore the factors associated with conviction and attrition such as the victim's character and credibility, prompt reporting of the offense, victim-offender relations, and evidence of nonconsent.

The project began with a more simple aim: to summarize Englishlanguage studies of rape case handling by the police and courts. However, we soon discovered that there were widely varying estimates of attrition and conviction in the literature. Authors cited different studies or selected findings or focused on some jurisdictions or countries. Conviction rates were given, but often it was not clear if they pertained to any offense or to the original offense charged, and researchers calculated estimates and defined outcomes in different ways.

Research on the prevalence of rape and its legal handling is highly politicized and contested. Victim advocates are criticized for providing "widely inflated estimates" of sexual victimization (Gilbert 1997, p. 101), and skeptics can be criticized for not understanding sexual violence in more fluid terms, as a continuum (Kelly 1988). Legal definitions of rape have changed in the last three decades, but the more consequential change is social and political. This was encapsulated in early feminist challenges to the "real rape" construct, that rape is carried out by a stranger, using a weapon, and with serious victim injury (Estrich 1987), when the more typical rape is by a known person, without a weapon, and without physical evidence of nonconsent. As legal

\footnotetext{
${ }^{1}$ Since September 2007, New Zealand has completed a rape attrition study (Triggs et al. 2009). Other studies that are planned or under way include the Irish Rape Attrition Project (2010), a rape attrition study of 11 U.K. and European countries (Lovett and Kelly 2009), the Understanding Attrition in Rape Cases Project in Sussex (McMillan and Thomas 2008), and a rape attrition study planned for South Africa (Gender, Health and Justice Research Unit 2008). Johnson, Ollus, and Nevala (2008) report estimates from the International Violence Against Women Survey that we cite when relevant.

${ }^{2}$ We initially combined England and Wales and Scotland but then decided to treat them separately because their rape law and criminal procedures differ, as do their attrition rates over time. In Scotland, unlike England and Wales, the definition of rape is still gender specific, although this is changing. The Scottish criminal justice system includes an additional stage, that of the procurator fiscal, who takes on some duties of the police and the prosecution (personal communication with Michele Burman, January 24, 2008).
} 
definitions and sociopolitical understandings of rape widened and as advocacy for victims grew from the 1970s onward, research on rape has been caught up in a politics of rape. Debates initially focused on rape prevalence (e.g., was it an epidemic or not?). In the past decade, debates have matured, but governments have been called on to do more. Low or declining conviction rates, faulty or questionable police investigations, and poor treatment of rape victims have put pressure on governments to review rape laws and legal procedure, not for the first time, but yet again.

As our research progressed, the need to create an authoritative and comprehensive record of what is known about rape and its handling in the legal process became clear. Reviews by Bryden and Lengwick (1997), Kelly (2001), Lievore (2004), Koss (2006), and Du Mont and White (2007) consider the prevalence and contexts of sexual victimization, victims' reporting patterns, and justice system responses. However, ours is the first study to assemble and harmonize the relevant body of research to estimate rates of conviction and of case attrition at different stages of the legal process and to identify factors associated with case attrition or retention. To provide a comparative context and understanding of the patterns that may emerge, we also review rape law reform and compare police statistics and court outcomes in the five countries studied.

A note on definitions. Rape is "unwanted oral, anal, or vaginal penetration against consent through force, threat of force, or when incapacitated" (Koss 2006, p. 208). It includes sexual intercourse with children (typically at law, under 16). "Rape" differs from "sexual assault" and "all sexual offenses." Sexual assault refers to a wider set of offenses, including penetrative (i.e., rape) and nonpenetrative (e.g., indecent assault) offenses that touch the body sexually. "All sexual offenses" include rape, sexual assault, and "no touch" offenses (e.g., indecent behavior or sexual exposure). Although most attrition research is concerned with the sociolegal response to rape (i.e., forced penetrative sex), victimization surveys, attrition studies, and official police and court data may include a broader set of offenses and victims of varied age groups. ${ }^{3}$ For simplicity of expression, we use victim and offender throughout the essay, without the "alleged" preface, and we use victim rather than survivor or victim-survivor.

\footnotetext{
${ }^{3}$ Because the composition of offenses varies, depending on the study or official data source, we use the more generic terms "sexual victimization" or "sexual offenses."
} 
Here are our major findings. Of sexual offenses reported to the police during the past 35 years, the overall rate of conviction to any sexual offense is 15 percent. ${ }^{4}$ When an early period (1970-89) is compared with a later period (1990-2005), this rate has declined significantly ${ }^{5}$ from 18 to 12.5 percent. Significant decreases have occurred in England and Wales, Canada, and to a lesser degree in Australia, but not in the United States or Scotland. Across the three decades, the overall rate of conviction to any sexual offense is a bit higher in samples of child or youth victims than those of mixed age or adults only. Significant decreases in conviction rates over time are evident in samples of mixed age and child or youth victims and across all types of sexual offenses.

With regard to where attrition occurs in the legal process, the following are averages across countries for the more recent period. Of sexual offenses reported to the police, 30 percent proceed past the police to prosecution, 20 percent are adjudicated in court, 12.5 percent are convicted of any sexual offense, and 6.5 percent are convicted of the original offense charged. Few cases go to trial ( 8 percent) and are convicted at trial ( 4.5 percent). Attrition is greatest at the start of the sociolegal process: from victimization surveys, an average 14 percent of victims report the offense to the police. Once reported, a minority of cases proceed past the police to the prosecutor's office, and this occurs for a variety of reasons. Suspects cannot be identified or located, victims withdraw complaints, and the police believe that there is insufficient evidence to charge a suspect or the victim's story lacks credibility. Attrition averages do not tell the whole story and can be misleading because there are significant differences by country and time period in the police and court handling of cases.

One explanation for decreasing conviction rates is that as more sexual offenses are reported to the police, they contain a higher share of known relations and rape contexts that do not accord with the real rape construct. At the same time, police, prosecutorial, and court decisions continue to operate with the real rape construct in mind. We find that this explanation applies best to England and Wales but is less evident in other countries. Of the four countries with sufficient re-

\footnotetext{
${ }^{4}$ The terms "overall rate of conviction" and "overall conviction rate" refer to the proportion of cases reported to the police that are convicted of any sexual offense.

${ }^{5}$ When we say "significantly" here and elsewhere in discussing the results, the reference is to statistically significant differences.
} 
search, the United States is an anomaly with no change in conviction rates over time. There is no one pattern of conviction and attrition in the countries studied.

We recognize that legal reforms of the past several decades may have helped some victims, but all commentators agree that the gains have been modest. We call for a shift in the priorities of legal reform-away from the trial and toward mechanisms of encouraging admissions to offending, which includes pursuing alternative pathways of participation and support for victims, offenders, and others affected by sexual offenses.

This essay has six sections. Section I reviews research and survey data on the prevalence of rape, on reporting to the police, and on case processing in the prosecutorial and judicial systems. It also discusses charges in rape law in the five countries. Section II sets out questions and related hypotheses examined in later sections. Section III describes the scope of the analysis, our strategy for locating relevant studies, problems of data comparability, and how estimates of conviction and attrition were calculated (app. B discusses these matters in more detail). Section IV presents and discusses the main findings. In Section $\mathrm{V}$ we examine our findings in relation to the questions and hypotheses set out in Section II. The final section puts forward ideas for more innovative and effective responses to rape and sexual assault, including cases that are not reported to the police and those that are reported, but subsequently withdrawn in the criminal process.

\section{Attrition Research in Comparative Context}

To understand patterns of rape case attrition over time and across different jurisdictions requires attention to a wider social and legal context. Since the 1960s and 1970s, with the rise of second-wave feminism, the legal definitions and social meanings of rape began to change. Major challenges were raised by feminist scholars about the veracity of official data and the harsh treatment of victims in the legal process.

\section{A. Was It Rape? Reporting Rape to the Police and Legal Responses}

Estrich's (1987) review of the literature up to the mid-1980s analyzed the interrelationships among victims' experiences of rape, sample survey estimates of victimization, victims' reports to the police, and how cases were handled by the police and courts. She coined the term 
"real rape," drawing from Kalven and Zeisel's (1966, p. 252) term "aggravated rape." Real rape has one or more of these elements: stranger relations, multiple assailants, weapon use, and evidence of serious physical injury. Or as Estrich says, the real rape image is of an "armed man jumping from the bushes" (p. 8). By contrast "not real" rape (also termed "simple" rape) has none of these aggravating elements: the offender is a lone man, whom the woman knows (a neighbor, an acquaintance, a date), using no weapon, and leaving no physical injuries or bruises on a victim. ${ }^{6}$ Estrich argued that in simple rape contexts, questions about a woman's character, credibility, and believability were especially likely to be raised. Although real rape was reported to the police by victims and treated seriously by the criminal justice system, simple rape was "far more common, vastly underreported, and dramatically ignored" by the police and courts (p. 10).

From early victimization surveys in the United States (the National Crime Surveys [NCS] conducted during 1973-82), the Bureau of Justice Statistics (1985) estimated that 52 percent of rapes (both attempted and completed) were reported to the police. It soon became apparent that the NCS had grossly underestimated the prevalence of rape and overestimated the likelihood of victim reports to the police because of the way in which the survey questions were asked. Other studies in the United States appeared at the time (e.g., Russell 1975; Williams 1984; see Estrich 1987, pp. 11-14) showing that women who were sexually assaulted by persons they knew (acquaintances, friends, neighbors, or relatives) were far less likely to report the offense to the police and to victim survey interviewers compared to women who were assaulted by strangers.

The Sexual Experiences Survey, developed by Koss and colleagues in the mid-1980s (Koss and Gidycz 1985; Koss, Gidycz, and Wisniewski 1987), broadened the behaviors associated with rape. Using this instrument, the authors found that the rate of rape was at least 10 times greater than that estimated from the NCS (see Johnson, Ollus, and Nevala 2008, pp. 10-14). ${ }^{7}$ In 1992, the NCS sexual and domestic

\footnotetext{
${ }^{6}$ Although Estrich (1987) draws from Kalven and Zeisel's (1966) work in defining real rape, her analysis focuses mainly on different responses to stranger and known relationship cases.

${ }^{7}$ Although Koss and colleagues were criticized by Gilbert (1997) for overestimating prevalence, a more recent study of victimization on U.S. college campuses vindicates Koss's point that estimates change dramatically, by 10 times, when questions are asked differently (see Fisher, Cullen, and Turner 2000, pp. 11-14).
} 
violence victimization questions were redesigned, and special modules were introduced in the British Crime Survey in 1994 to elicit respondents' experiences with rape and sexual assault. Both led to significant increases in the estimated rates of sexual victimization. In 1993, Statistics Canada fielded the first national survey of women's experiences of sexual and physical victimization, which used more sensitive approaches to elicit information and conduct the interviews (see a review of methods used in Johnson and Sacco [1995] and Johnson [1996]); their approach was adopted in other countries during the 1990s. The International Crime Victim Survey (ICVS) began to gather victimization data in 1989 from 60 countries (now numbering 70 countries), but it was not designed to elicit an understanding of female experiences of sexual or physical victimization. To address this problem, the International Violence Against Women Survey (IVAWS) project was established as an international comparative survey of women's experience of sexual and physical violence and of criminal justice responses. After pilot studies in 2001 and 2002, the first survey was carried out during 2003-5 in 11 countries of the developed and developing world. Publications are now emerging (see, e.g., Mouzos and Makkai [2004] for Australia and Johnson, Ollus, and Nevala [2008] for the entire sample) that present a complex picture of victimization and reporting patterns, with an analytical emphasis on partner and nonpartner violence. ${ }^{8}$

Several observations can be made. Reliable estimates of female sexual victimization and associated estimates of reports to the police are recent. Such estimates depend on how the questions are asked and the degree to which the interview context is supportive of participants. As methodologies improve to elicit the frequency, types, and contexts of rape and sexual assault and the estimated incidence of sexual victimization increases, the rate at which women tell survey researchers that they reported the offense to the police decreases. Thus, when victimization surveys capture a larger share of "nontraditional" rapes (simple rapes and those involving known relations), the rate at which victims say to interviewers that they reported the offense to the police goes down. Likewise, the composition of reports received by the police may have an increasingly larger share of nontraditional rapes over time because there are more supports and services for victims, coupled with a

${ }^{8}$ Where relevant, we draw on the IVAWS findings. However, just one of the five countries in our study (Australia) participated in the IVAWS. 
changed consciousness about rape, to bring these incidents to police attention.

Table 1 itemizes the major surveys of sexual victimization conducted since 1992 in four countries that are the subject of this study. It shows that across all the surveys, the rates of report to the police range from 6 percent (the first victim-friendly survey in Canada) to a high of 32 percent (a standard victimization survey in the United States, albeit with redesigned questions). When the latter unusually high estimate is excluded, the average rate of victim report is 14 percent. ${ }^{9}$ By country, rates of report are 15-19 percent (United States), 14-18 percent (England and Wales), 12-20 percent (Australia), 6-19 percent (Canada), and 12 percent (New Zealand).

For age, surveyed victims are typically 16 or older, and the youngest age group (16-24 years) has the highest rate of sexual victimization. Where data are available, however, the highest rate of sexual victimization is found for those 10-14 years (Snyder 2000; AIC 2008). In research on child and youth victims (those 12-17 years), the rate of reporting sexual victimization to the police ranges from a high of 30 percent for "violent sexual assault" from the National Crime Victimization Survey (NCVS; Finkelhor and Ormrod 1999) to 13 percent for "sexual assault" (Kilpatrick and Saunders 1997) and to a low of 3 percent for "sexual victimization" (Finkelhor and Dziuba-Leatherman 1994; cited in Finkelhor, Wolak, and Berliner 2001, p. 18). Although the number of studies is small (and all are from the United States), they suggest a somewhat lower likelihood that child and youth victims report sexual victimization to the police than adult victims.

Why, on average, do 86 percent of victims not report rape and sexual assault to the police? The reasons given by victims, often in combination, are not viewing the assault as rape or not thinking that others will view it as rape; fearing that others will disbelieve or blame her, including family members or friends; fearing or distrusting the police and court processes; fearing threats or further attacks by the offender or his family and friends; and having divided loyalties when reporting a family member or ex-partner (Kelly 2001, pp. 9-10; Lievore 2003). Because many victims are unsure about what to do or may blame them-

\footnotetext{
${ }^{9}$ By comparison, estimates of reports to the police for nonpartner sexual violence, drawing from the IVAWS project, are somewhat lower: ranging from 4 percent (Poland), to 6-8 percent (Costa Rica, Denmark, Australia, and the Czech Republic), to 13 percent (Mozambique; Johnson, Ollus, and Nevala 2008, fig. 6.12, p. 147; table III.12, p. 210).
} 
selves, they may delay their report to the police. The police, in turn, may interpret delay as a sign that the assault was not serious or that a victim is not being fully truthful. Young women's potential for victimization is high in social occasions in which alcohol or illegal drugs are used. These contexts heighten a risk of what is termed "acquaintance" rape, although the assaults may be viewed by victims, general members of society, and legal authorities as nontraditional forms, not as real rape.

\section{B. Real Rape and Victim-Offender Relations}

An important question for attrition research is whether the relative composition of aggravated and simple rapes, or of stranger rapes, reported to the police has changed over time. In England and Wales, attention has been drawn to the growing gap between women's reports to the police and a diminished rate of court convictions (Kelly, Lovett, and Regan 2005, p. 25). One explanation is that an increasing share of nontraditional rapes, which are more difficult to prove in court, are being reported to the police.

Evidence from varied jurisdictions over time is lacking on victimoffender relations and reporting patterns, but two studies are relevant. Baumer's (2004) analysis of the NCS for 1973-91 finds that of the 51 percent of rapes that victims said they reported to the police, half involved known persons. Data from the redesigned NCVS for 19922002 show that of the 30 percent of rapes that victims said they reported to the police, 84 percent involved known persons. From multivariate analyses, Baumer finds that in the 1970s and 1980s, women were less likely to report being raped by a known person than by a stranger, but by the early 1990s, victim-offender relationships had no effect on the likelihood that victims reported rape offenses to the police. He suggests that increases in victims' reports of nonstranger rapes can be attributed to changing perceptions of and broadened definitions of rape that include acquaintances and intimates. The second study, by Harris and Grace (1999), compares British Home Office data for 1985 and 1996 on the stranger share of cases reported to the police. They find a drop in the stranger share from 30 percent to 12 percent (see also Grace, Lloyd, and Smith 1992).

To pursue this question further, we identified a subsample of cases from our attrition sample that examined victim-offender relations as an attrition factor and then reread each to determine the stranger re- 
TABLE 1

Rates of Reporting Sexual Assault Victimization to Police

\begin{tabular}{|c|c|c|c|c|}
\hline Source and Citation & $\begin{array}{l}\text { Rate of Report } \\
\text { to Police (\%) }\end{array}$ & Country & Survey Year & $\begin{array}{l}\text { Age of } \\
\text { Victim }\end{array}$ \\
\hline $\begin{array}{l}\text { National Crime Victimization Survey (NCVS) } 2000 \text { (Rennison 2002, } \\
\text { p. 1) }\end{array}$ & 32 & United States & 1992-2000 & $12+$ \\
\hline Crime and Safety Australia 2002 (ABS 2003, pp. 28-29) & 20 & Australia & 2002 & $18+$ \\
\hline $\begin{array}{l}\text { National Violence Against Women Survey (NVAWS) 1995-96 } \\
\text { (Tjaden and Thoennes 2006, pp. 7, 33-34) }\end{array}$ & 19 & United States & 1995-96 & $18+$ \\
\hline $\begin{array}{l}\text { International Crime Victims Survey (ICVS) (van Kesteren et al. } \\
\text { 2000, pp. 188, 194) }\end{array}$ & 19 & Canada & 2000 & $16+$ \\
\hline British Crime Survey (BCS) (Myhill and Allen 2002, p. 1) & 18 & England and Wales & $1998,2000^{\mathrm{a}}$ & $16+$ \\
\hline $\begin{array}{l}\text { International Crime Victims Survey (ICVS) (van Kesteren et al. } \\
\text { 2000, pp. 189, 195) }\end{array}$ & 15 & United States & 2000 & $16+$ \\
\hline
\end{tabular}


Women's Safety Survey (ABS 1996, pp. 4, 32)

International Crime Victims Survey (ICVS) (van Kesteren et al. 2000, pp. 188, 194)

International Crime Victims Survey (ICVS) (van Kesteren et al. 2000, pp. 188, 194)

International Violence Against Women Survey (IVAWS) (Mouzos and Makkai 2004, pp. 2, 102)

New Zealand National Survey of Crime Victims 2001 (Morris and Reilly 2003, para. 3.2)

General Social Survey on Victimization (Kong et al. 2003, p. 6)

Violence Against Women Survey 1993 (WAVAW 2005)

$\begin{array}{rlll}15 & \text { Australia } & 1996 & 18+ \\ 15 & \text { Australia } & 2000 & 16+ \\ 14 & \text { England and Wales } & 2000 & 16+ \\ & & & \\ 12^{\mathrm{b}} & \text { Australia } & 2002-3 & 18+ \\ & & & \\ 12 & \text { New Zealand } & 2000-2001 & 15+ \\ 8 & \text { Canada } & 1999 & 15+ \\ 6 & \text { Canada } & 1993 & 18+\end{array}$

Mean rate of reporting to police ${ }^{c}$

${ }^{a}$ Because of the small number of females reporting sexual victimization, responses on sexual victimization for two waves of the BCS (1998 and 2000) were combined.

${ }^{\mathrm{b}}$ This is the rate for sexual assault by nonpartners; sexual assault by partners is 15 percent.

${ }^{\mathrm{c}}$ Excludes the U.S. rate of 32 percent, which is an outlier. 
lationship share of offenses reported to the police. A data set of 27 studies was initially assembled, but the number was reduced to 13 ; these clearly specified the stranger share of cases reported to police. ${ }^{10}$ The 13 studies were mainly from the United States and England and Wales, with one each from Australia and Canada. Our ministudy found that stranger relations were a significantly higher share of cases reported to the police in the 1970s and 1980s (48 percent) than in the 1990s forward (26 percent). Although the sample size is small, the findings confirm that the stranger relations share of rapes reported to the police has decreased over time.

\section{Legal Reform and Its Impact}

When one compares rape case handling by country, a key element is variation in legal reform. There are several dimensions to consider: first, country differences in the timing and scope of rape law reform; second, the elements that are typically part of rape law reform; and, third, research on the effects of rape law reform on police and court handling of cases. A complicating factor is that rape law reform likely affects victims' reporting patterns to the police. As our discussion above suggests, one consequence of rape law reform is that a higher share of reported rapes involve known relations, and this may result in decreased convictions.

Country differences exist in the timing and scope of rape law reform. Reform emerged in the mid-1970s in the United States and Australia, soon followed by Canada in the early 1980s. Legal change came much later to England and Wales and Scotland. Some amendments were made to English law during the 1970s and 1990s, but no comprehensive legislative change occurred until 2003, with the passage of the Sexual Offences Act 2003. In Scotland, some reform was introduced in the mid-1980s and again in 2002, but comprehensive reform has not yet been introduced. ${ }^{11}$

Before rape law reform, a victim's character, behavior, and sexual history were relevant and lawful factors in decisions; there needed to

\footnotetext{
${ }^{10}$ The excluded studies were those that began with police "founded" or "crimed" cases, offenses cleared by arrest, cases referred to prosecution, or defendants in court. All of these are affected by victim-offender relations, and especially the latter three, in the profile of suspects who can be identified.

${ }^{11}$ We schematize developments in rape law reform. Evidence for and definitions of "consent" (or nonconsent) in rape law are complex and have been evolving in the past decade; they are not addressed in detail here.
} 
be witness corroboration of a victim's statement and substantial evidence of victim resistance and injury. Rape was defined as forced vaginal intercourse only, and husbands were exempt from prosecution. When legal reforms were introduced, the aim was to shift attention away from a victim's character and sexual history to an offender's behavior, to eliminate the witness corroboration rule and other stringent physical evidence requirements to prove nonconsent, and to expand the definition of rape.

In the United States, all the states enacted rape law reforms by the mid-1980s (Futter and Mebane 2001), although these varied in scope and comprehensiveness. They include rape shield laws that restricted using evidence at trial about a victim's sexual history, elimination of the corroboration rule, and in some states, elimination of evidence of physical resistance. The definition of rape expanded from the single offense of rape (vaginal intercourse with the penis) to a series of graded offenses that were associated with aggravating circumstances and acts. Sexual intercourse was broadened to include oral and anal penetration and male victims. By 1993, marital rape was criminalized in all states (Bergen 2006).

Frohmann and Mertz (1994, p. 831) suggest that legal reform had dual goals of efficacy (i.e., increasing the likelihood of conviction) and process (i.e., "attention to women's perceptions and experience of the process itself"), but these goals did "not always coincide." For example, a prosecution may result in conviction, "but also devastation for the victim." Drawing from Spohn and Horney's (1992) key work, they concluded that with some exceptions, legal reforms had little or no effect on rates of reporting rape, prosecution, and conviction. Despite the good intentions of professionals, organizational or professional priorities often trumped victims' needs (Frohmann and Mertz 1994, pp. 832-35). Reviewing the effects of legal reform in the United States 15 years later, Koss (2006, p. 217) said that although feminist and victim movements "achieved spectacular success by the standards of social change," reforms had positively affected only a small number of women, drawing from Bryden (2000), Seidman and Vickers (2005), and Bublick (2006) (see also Schulhofer 1998, chap. 2).

In Australia, as in the United States, major legal reforms were introduced in all the states, beginning in the mid-1970s, although they varied in scope and intensity (Bargen and Fishwick 1995; Heath 2005). Legal reform addressed key areas of a victim's sexual history, witness 
corroboration, physical resistance (and associated definitions of consent), and definitions of rape and sexual intercourse. As in the United States, several Australian studies on the impact of legal reform (Brereton 1994; NSW Department for Women 1996) found that older practices continued, despite legal change. During the early 2000s, major reviews of rape law and procedure were undertaken in most states, including Victoria, New South Wales, South Australia, and Western Australia.

In Canada, comprehensive legislative change was introduced in 1983 , with reforms aimed at encouraging victims to report rape to the police and limiting the introduction of evidence on a woman's sexual history. Rape was redefined as a type of assault with varying degrees of seriousness, and it included marital rape and male victims. Roberts (1996) reports that between 1983 and 1994, rape reporting to the police increased by 130 percent, with much of the increase occurring in the years immediately following the introduction of legal reform. However, Tang (1998, p. 263) suggests that for Canada, "sexual assault is still under-reported; victims fear the system is biased against them. Founding, charging, and conviction rates remained low." Gunn and Linden (1997) attempted, but were not able, to confidently estimate conviction rates in the pre- and postreform years.

In England and Wales, several amendments were made to the Sexual Offences Act 1956 to redefine rape. In 1976, a shift was made from "against her will," with evidence of physical resistance required, to "without her consent"; in 1994, rape definitions were broadened to include male and marital rape (see Temkin 2002). The Sexual Offences Act 2003 consolidated what had been piecemeal changes up to that time, and it introduced two major areas of change: widening the definition and scope of rape and sexual offenses and changing the definition of consent. As in Australia and Canada, the recent legislation in England and Wales provides a statutory definition of consent, including a list of circumstances when consent is not possible (see Temkin and Krahé 2008, pp. 26-27).

Legal reform came last to Scotland. Changes to the rape shield laws were first introduced in 1986 and extended in 1995 and 2002. Brown, Burman, and Jamieson (1993) and Burman et al. (2007, p. 8) conclude that the 1986 and 1995 legislation was "largely ineffective"; indeed, after the 2002 act, Burman et al. find that "more sexual history and character evidence [was being introduced than before]" (p. 7). Scot- 
land's rape law includes only female victims, and its corroboration rule is still in place, although it applies to all offenses, not just rape (personal communication with Michele Burman, January 24, 2008).

Of the 75 cases analyzed in our study, just 12 (or 16 percent) were carried out before any legal reform in that jurisdiction, and an additional 11 percent were conducted in jurisdictions after some reform. Of the 12 prereform cases, most (nine) are from U.S. jurisdictions, two from Canada, and one from Scotland. Thus, studies of the police and court response to rape are largely of practices after the introduction of reforms in specific jurisdictions or countries.

Rape law reform is a long-term process of efforts to change legal culture, organizational and professional practices, and attitudes toward and beliefs about men's and women's sexualities, culpabilities, and responsibilities for sexual victimization. There is a long line of actions and interactions between the passage of a law and changes in people's attitudes and behaviors that give effect to that law; and as Smart (1989) suggests, the law is itself resistant to change. Although virtually all commentators suggest that there has been little or no significant impact of legal reform, we hypothesize that countries initiating reform earlier (the United States, Australia, and Canada) would show different conviction patterns than England and Wales and Scotland, which initiated reform much later. At the same time, we recognize that legal reform, coupled with research infrastructure and support services to victims, has likely affected victims more than criminal justice officials or legal practices. This is evident from several studies of victim reporting patterns (Harris and Grace 1999; Baumer 2004), including our ministudy. To explore this matter further, we turn to an analysis of crimes reported to the police over time by country.

\section{Rape and Sexual Assault Recorded by Police}

In reviewing official police data, we have three aims: to determine if there is a relationship between the emergence and consolidation of legal reform and rates of reported rape and sexual assault to the police, to identify country differences or patterns, and to consider how official police data may inform our analysis of attrition research.

It is widely recognized that official police data do not accurately reflect the true incidence of rape or sexual assault or increases and decreases over time. However, our aim is to glean general patterns from the data (see fig. 1). An immediate problem in attempting to make 


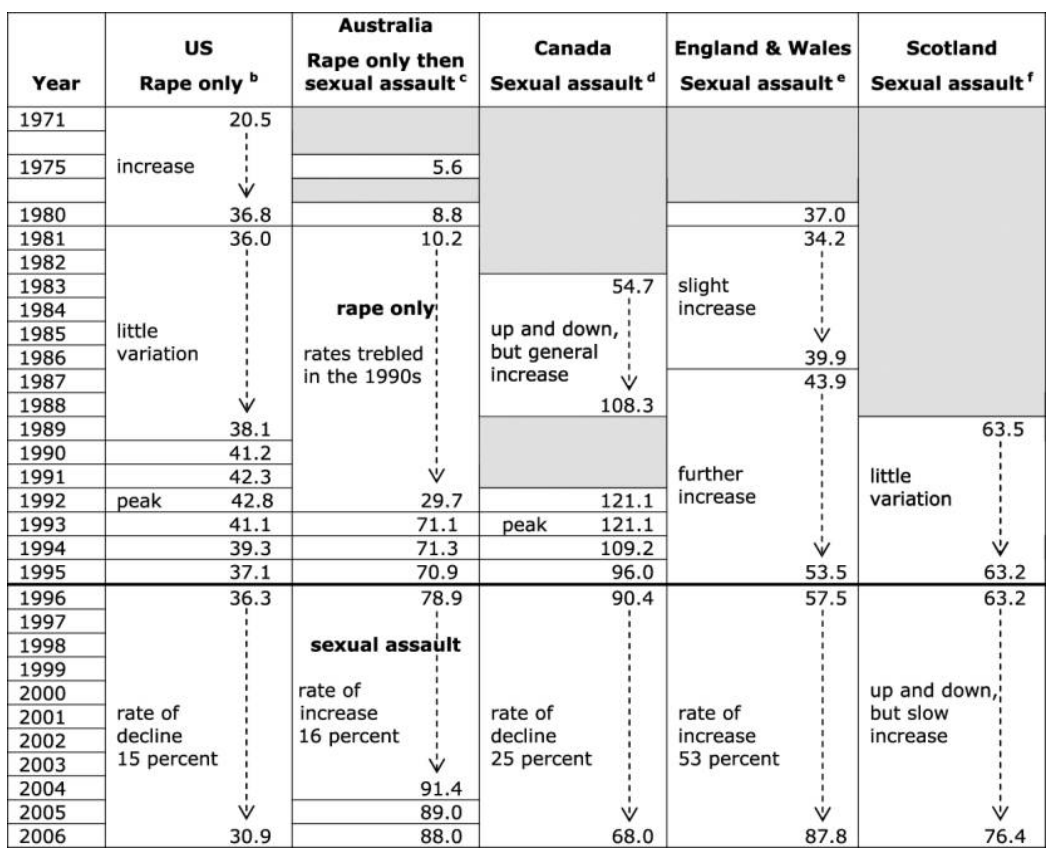

FIG. 1.-Rates of rape and sexual assault recorded by police (per 100,000 population). ${ }^{2}$ ${ }^{a}$ Population includes males and females of all ages. For all countries except the United States, data include male and female victims. ${ }^{b}$ Data include only forcible rape of females and are from Bureau of Justice Statistics Data Online (http://bjsdata.ojp.usdoj.gov/dataonline). ${ }^{c}$ Data for 1974-92 include only rape and are from Walker (1994, pp. 6-7). Data for 1996-2006 include penetrative offenses (rape and USI) and nonpenetrative offenses (indecent assault). Rates for 1993-95 are from ABS (1994, p. 5; 1996, pp. 13-14). Data for 1996-2006 are from AIC (2008, p. 9) and were calculated using population data from ABS (2002, table 5.1 for 1996-2000; 2008, table 7.1 for 2000-2005). ${ }^{\mathrm{d} D a t a}$ include penetrative offenses (rape) and nonpenetrative offenses (indecent assault), and sexual offenses against children (level 1, 2, and 3 sexual assault). Data for 1983-88 are from Roberts and Gebotys (1992, p. 563); for 1992-96, from Kong (1997, p. 15); for 1997-2001, from Savoie (2002, p. 14); and for 2002-6, from Silver (2007, p. 9). Rates for 1983-96 were calculated using population data from Sustainability Report (2008). ${ }^{e}$ Data include penetrative offenses (rape and USI) and nonpenetrative offenses (indecent assault). Data for 1979-89 are from Home Office (1989, p. 41); for 1990-95, from Home Office (1996, p. 58); for 1996, from Walker et al. (2006, p. 27); and for 1997-2006, from Sian et al. (2007, p. 37). Rates for 1979-95 were calculated using population data from Office for National Statistics (1997, p. 51); for 1996-2006, from National Statistics Online (2008, table 1.2). ' Data include penetrative offenses (rape and USI) and nonpenetrative offenses (indecent assault). Data for 1988-96 are from Scottish Executive (1998, online table) and for 1997-2006, from Scottish Executive (2007b, p. 12). Rates for 1979-95 were calculated using population data from Office for National Statistics (1997, p. 51); for 1996-2006, from National Statistics Online (2008, table 1.2). 
comparisons is that countries count different types of sexual offenses. As detailed in the figure notes, the United States counts rape only; Australia counted rape in the 1980s but then shifted to the broader category of sexual assault in the 1990s; and Canada, England and Wales, and Scotland count sexual assault. To compare recent patterns, we focus on rates of increase or decrease from 1996 to 2006.

In the United States, rates of reported rape to the police remained steady in the 1980s (after major increases in the 1970s); they peaked in the early 1990s and began to decline, with a 15 percent rate of decline from 1996 to the present. For Canada, rates of reported sexual assault increased during the 1980s. As in the United States, they peaked in the early 1990s and began to decline in 1994-95 and have declined since then (25 percent rate of decline from 1996 to the present). For Australia, rates of reported rape increased substantially in the 1980s. In contrast to the United States or Canada, rates of reported sexual assault in Australia increased somewhat from 1996 to 2004 (16 percent rate of increase), with a suggestive decreasing trend to 2006. The picture for England and Wales differs markedly. During the 1980s and to the mid-1990s, there were small but steady increases each year in reported sexual assault, but from 1996 to 2006, the rate of increase grew substantially (a 53 percent rate of increase). ${ }^{12}$ Available data for Scotland show up-and-down fluctuations of reported sexual assault from 1996 to the present, with a suggestive upward trend.

These data suggest a relationship between rates of reported rape or sexual assault and the rise and consolidation of significant legal reform. Early reform countries (the United States, Australia, and Canada) do show substantial increases coinciding with legal reform, although these occurred earlier in the United States (in the 1970s) than in Australia and Canada (in the 1980s). By comparison, in England and Wales, a later reform country, rates of reported sexual assault did not begin to rise substantially until the late 1980s and have since shown a high rate of increase. In Scotland, where legal reform is still under way, rates of reported sexual assault were not counted until 1989; from then to 2006, there is a small increase.

There are also notable country differences. In the United States and Canada, after peaking in the early 1990s, rates have since declined. In Australia, rates increased slightly from the mid-1990s to 2004 but have

\footnotetext{
${ }^{12}$ Although England and Wales experienced a large rate of increase from 1996 to 2006, its rate of reported sexual assault in 2006 was about the same as Australia's.
} 
since stabilized or declined somewhat. By contrast, England and Wales is exceptional in its large rate of increase in reported sexual assault from 1996 to 2006.

On the basis of these data, we would expect to see distinctive patterns in attrition research for England and Wales. With strong increases in reported sexual assault, there would be significant pressure on police organizational resources and routines to process cases, with one result being higher rates of attrition at the police stage. Making inferences from a country's police data to the findings from its attrition research is, of course, tenuous. Police data are gathered for an entire country (and three of the five countries are very large and geographically dispersed), whereas attrition studies come from selected cities or states, which may vary greatly in police and court practices.

\section{E. Published Court Data}

Attrition is smaller at the court stage, but it is at this stage when victims are most visibly subject to a second victimization by the trial process (NSW Department for Women 1996; Temkin and Krahé 2008). There are problems comparing countries' court data, but the statistics may offer broad clues about court culture and organizational practices. ${ }^{13}$

Three problems arise in comparing the court data. First, the published statistics for England and Wales do not show the number or percentage of "other outcomes" (i.e., cases that are dismissed, withdrawn, or not proceeded with); data from all the other countries do. With these cases excluded, the conviction rate for England and Wales is inflated and not comparable to that of other countries. ${ }^{14}$ Second, with "other outcomes" excluded in the British data, the trial rate also cannot be compared with that of other countries. Third, Canada and Scotland do not report the number of cases that go to trial or trial outcomes.

Table 2 presents the available court data on conviction rates, trial

\footnotetext{
${ }^{13}$ Some have asked if attrition for rape is any different from that for murder or robbery (see, e.g., Myers and LaFree 1982; Galvin and Polk 1983). The answer is that we do not know when the base is crimes reported to the police. We analyzed the countries' court data for 2001-6 and found that once cases are in court, conviction for rape is ranked third or tied in second place with homicide/murder or robbery. In no country is conviction for rape ranked in first place. Garner and Maxwell's (2009) analysis of attrition for intimate partner violence finds an overall average conviction rate of 16.4 percent. Their paper can be read as a companion piece to ours.

${ }^{14}$ The same approach is taken by the Australian Bureau of Statistics (2007) in its compilation of Australia-wide court data; for that reason, we do not rely on that source but use more complete data from South Australia.
} 
rates, and conviction at trial. Column 1 , outcome $\%$ of total cases, shows that in the United States and South Australia, 31 percent of cases are not proceeded with, dismissed, or withdrawn. However, the share of guilty pleas is much higher in the United States (61 percent) than in South Australia (37 percent). In column 2, the trial rate is calculated in two ways. First, the trial rate is the percentage of all cases in court (including "other outcomes") that go to trial ${ }^{15}$ and then the comparison trial rate, in parentheses, is calculated as $N$ of cases going to trial/( $N$ of guilty pleas $+N$ of cases going to trial). We can use this second figure in comparing the British trial rate with that in other countries. Column 4 presents the conviction rate for trial cases and for total cases (i.e., the denominator includes "other outcomes").

Table 2 suggests that court processes vary by country. First, the conviction rate of total rape cases (rape or rape and unlawful sexual intercourse [USI]) is higher in the United States (67 percent) than in South Australia, Canada, and Scotland, where it ranges from 47 to 52 percent. Second, the trial rate for the United States is lower than that for South Australia (respectively, 8 percent and 32 percent), but the rate of conviction at trial is higher (respectively, 74 percent and 47 percent). In the Scottish data, the conviction rate for indecent assaults (nonpenetrative offenses) is higher than it is for rape (78 percent and 47 percent, respectively). Offense and age-based differences in conviction rates are explored further in the next table.

Table 3 assembles data from New South Wales and Victoria to determine if trial rates and rates of conviction vary by the age of victims and type of offense. In New South Wales, for offenses against children (defined as under 18 years), the trial rate is 33 percent, the rate of conviction at trial is 45 percent, and the conviction rate for the total cases charged is 62 percent. However, for offenses against adults, the trial rate is higher ( 42 percent) and the rate of conviction at trial is lower (35 percent), as is the conviction rate for total cases (43 percent). A similar age-based pattern is evident when comparing rape and USI. The latter offense is relevant only to younger-aged victims, whereas rape can include victims of all ages. ${ }^{16}$ For rape, the trial rate is 46

${ }^{15}$ This definition of the trial rate is also used in our analysis of attrition research; see app. table B1.

${ }_{16}$ The precise victim age for USI varies by jurisdiction, but typically, it is less than 16 years. Further legal distinctions are made for USI with victims under 12 or 13 years, which is legally more serious. The key legal point is that nonconsent is not relevant in USI cases. Cases may initially be charged with rape, but a defendant may be permitted to plead to USI when the state's evidence of nonconsent is weak. 
TABLE 2

Court Cases and Conviction Rates for Rape

\begin{tabular}{ccccc}
\hline & $\begin{array}{c}\text { Outcome } \\
\% \text { of Total }\end{array}$ & $\begin{array}{c}\text { Trial Rate } \\
(\text { Comparison }\end{array}$ & & $\begin{array}{c}\text { Conviction } \\
\text { Rate }\end{array}$ \\
Charged Offense and Outcome & Cases & Trial Rate) & $N$ Guilty & Rate \\
\hline
\end{tabular}

A. United States, 2002
Rape and attempted rape
$(N=760)$ :
Guilty plea $(N=464)$
Trial $(N=61)$
Other outcomes $(N=235)^{\mathrm{b}}$
Total $N$ cases

\begin{tabular}{cccc}
\hline & & & \\
$61 \%$ & $\ldots$ & 464 & \\
$8 \%$ & $8 \%$ & 45 & $74 \%$ \\
& $(12 \%)$ & & (at trial) \\
$31 \%$ & $\ldots$ & 509 & $67 \%$ \\
760 & & & (all cases) \\
\hline
\end{tabular}

B. South Australia, 2001-5

Rape, attempted rape, and unlawful sexual intercourse $(N=463)$ :

Guilty plea $(N=170)$

Trial $(N=149)$

Other outcomes $(N=144)^{\mathrm{b}}$

Total $N$ cases

\begin{tabular}{cccc}
\hline & & & \\
& & & \\
$37 \%$ & $\ldots$ & 170 & \\
$32 \%$ & $32 \%$ & 70 & $47 \%$ \\
& $(47 \%)$ & & (at trial) \\
$31 \%$ & $\ldots$ & 240 & $52 \%$ \\
463 & & & (all cases) \\
& & & \\
\hline
\end{tabular}

C. Canada, 2005-6

Rape and attempted rape $(N=3,145)$ :

Total $N$ cases

\begin{tabular}{|c|c|c|c|}
\hline 3,145 & $\begin{array}{c}\text { No trial } \\
\text { information }\end{array}$ & 1,583 & $\begin{array}{c}50 \% \\
\text { (all cases) }\end{array}$ \\
\hline
\end{tabular}

D. England and Wales, 2005

\footnotetext{
Rape and unlawful sexual intercourse $(N=2,577)$ : Guilty plea $(N=802)$

Trial $(N=1,775)$

Other outcomes $^{\mathrm{b}}$

Total $N$ cases
}

$\begin{array}{ccc}\ldots & & \\ \text { Unknown } & 802 & \\ (69 \%) & 515 & \begin{array}{c}29 \% \\ \text { (at trial) }\end{array} \\ \ldots & \ldots & \begin{array}{c}\text { Cannot } \\ \text { determine } \\ \text { accurately }\end{array}\end{array}$


TABLE 2 (Continued)

\begin{tabular}{|c|c|c|c|c|}
\hline Charged Offense and Outcome & $\begin{array}{l}\text { Outcome } \\
\% \text { of Total } \\
\text { Cases } \\
\text { (1) }\end{array}$ & $\begin{array}{c}\text { Trial Rate } \\
\text { (Comparison } \\
\text { Trial Rate) } \\
\text { (2) }\end{array}$ & $\begin{array}{l}N \text { Guilty } \\
\text { (3) }\end{array}$ & $\begin{array}{c}\text { Conviction } \\
\text { Rate } \\
\text { (4) }\end{array}$ \\
\hline & \multicolumn{4}{|c|}{ E. Scotland, 2005-6 } \\
\hline \multicolumn{5}{|l|}{$\begin{array}{l}\text { Rape and attempted rape } \\
\qquad(N=126):\end{array}$} \\
\hline Total $N$ cases & 126 & $\begin{array}{l}\text { No trial } \\
\text { information }\end{array}$ & 59 & $\begin{array}{c}47 \% \\
\text { (all cases) }\end{array}$ \\
\hline \multicolumn{5}{|l|}{ Indecent assault $(N=108)$ : } \\
\hline Total $N$ cases & 108 & $\begin{array}{l}\text { No trial } \\
\text { information }\end{array}$ & 84 & $\begin{array}{c}78 \% \\
\text { (all cases) }\end{array}$ \\
\hline
\end{tabular}

SOURCE.-For the United States, data are from Cohen and Reaves (2006, p. 24); for South Australia, the Office of Crime Statistics and Research (2002-6); for Canada, Statistics Canada (2007); for England and Wales, Office for Criminal Justice Reform (2006); for Scotland, Scottish Executive (2007a). N's were calculated or adapted from percentages given in the sourced material.

${ }^{a}$ The comparison trial rate is calculated as $N$ cases going to trial/( $N$ guilty pleas + cases going to trial).

${ }^{\mathrm{b}}$ Depending on the jurisdiction, other outcomes are not proceeded with, dismissed, diverted, deferred, or withdrawn cases, or defendant failed to appear or died.

${ }^{\mathrm{c}}$ Published data show a conviction rate of 51 percent, but this excludes cases dismissed or withdrawn, is inflated, and cannot be compared to the other countries.

percent, the rate of conviction at trial is 48 percent, and the conviction rate for all cases charged is 65 percent. By comparison, for USI, the trial rate is lower (34 percent) and conviction at trial is higher (58 percent), as is the conviction rate for total cases ( 74 percent). These data suggest that cases involving adult victims and charges of rape face more hurdles in the legal process than those involving younger-aged victims and charges of USI. The results for age confirm patterns noted by Harris and Grace (1999, p. 32) for England and Wales: the highest rates of conviction are for younger-aged victims (under 13 years) and the lowest for women over 25.

For the comparison trial rates for rape and rape and USI (table 2), England and Wales has a most unusual pattern of a high trial rate (69 percent) and a very low conviction rate at trial (29 percent). The comparison trial rate for the United States is 12 percent; for South Australia, 47 percent; and for Victoria, 52 percent (rape) and 39 percent (USI); all have a much higher rate of conviction at trial than England and Wales. 
TABLE 3

Court Cases and Conviction Rates for Sexual Assault by Age of Victim (NSW) and Type of Offense (Victoria)

\begin{tabular}{|c|c|c|c|c|}
\hline Charged Offense and Outcome & $\begin{array}{l}\text { Outcome } \\
\% \text { of Total } \\
\text { Cases } \\
\text { (1) }\end{array}$ & $\begin{array}{c}\text { Trial Rate } \\
\text { (Comparison } \\
\text { Trial Rate) }{ }^{\mathrm{a}} \\
(2)\end{array}$ & $\begin{array}{l}N \text { Guilty } \\
\text { (3) }\end{array}$ & $\begin{array}{l}\text { Conviction } \\
\text { Rate } \\
\text { (4) }\end{array}$ \\
\hline & \multicolumn{4}{|c|}{ A. New South Wales, 2004-6 } \\
\hline \multicolumn{5}{|l|}{$\begin{array}{l}\text { Sexual assault and related offenses } \\
\text { against children }(N=827):^{\mathrm{b}}\end{array}$} \\
\hline Guilty plea $(N=390)$ & $47 \%$ & $\ldots$ & 390 & \\
\hline Trial $(N=272)$ & $33 \%$ & $33 \%(41 \%)$ & 122 & $45 \%$ (at trial) \\
\hline Other outcomes $(N=165)^{\mathrm{c}}$ & $20 \%$ & $\ldots$ & $\ldots$ & \\
\hline Total $N$ cases & 827 & & 509 & $62 \%$ (all cases) \\
\hline \multicolumn{5}{|l|}{$\begin{array}{l}\text { Sexual assault and related offenses } \\
\text { against adults }(N=793):^{\mathrm{d}}\end{array}$} \\
\hline Guilty plea $(N=223)$ & $28 \%$ & $\ldots$ & 223 & \\
\hline Trial $(N=331)$ & $42 \%$ & $42 \%(60 \%)$ & 116 & $35 \%$ (at trial) \\
\hline Other outcomes $(N=239)^{\mathrm{c}}$ & $30 \%$ & $\ldots$ & $\ldots$ & \\
\hline \multirow[t]{2}{*}{ Total $N$ cases } & 793 & & 339 & $43 \%$ (all cases) \\
\hline & \multicolumn{4}{|c|}{ B. Victoria, 1997-99 } \\
\hline \multicolumn{5}{|l|}{ Rape $(N=282):^{\mathrm{e}}$} \\
\hline Guilty plea $(N=119)$ & $42 \%$ & $\ldots$ & 119 & \\
\hline Trial $(N=130)$ & $46 \%$ & $46 \%(52 \%)$ & 63 & $48 \%$ (at trial) \\
\hline Other outcomes $(N=33)^{\mathrm{c}}$ & $12 \%$ & $\ldots$ & $\ldots$ & \\
\hline Total $N$ cases & 282 & & 182 & $65 \%$ (all cases) \\
\hline \multicolumn{5}{|c|}{ Unlawful sexual intercourse $(N=224):^{\mathrm{e}}$} \\
\hline Guilty plea $(N=121)$ & $54 \%$ & $\ldots$ & 121 & \\
\hline Trial $(N=77)$ & $34 \%$ & $34 \%(39 \%)$ & 45 & $58 \%$ (at trial) \\
\hline Other outcomes $(N=26)^{\mathrm{c}}$ & $12 \%$ & $\ldots$ & $\ldots$ & \\
\hline Total $N$ cases & 224 & & 166 & $74 \%$ (all cases) \\
\hline
\end{tabular}

SOURCE.-Data for New South Wales are from the NSW Bureau of Crime Statistics and Research (2007, p. 2). Data for Victoria on rape are from Victorian Law Reform Commission $(2001$, pp. 42, 194) and on USI from Victorian Law Reform Commission (2003, pp. 89, 94-95). N's were calculated or adapted from percentages given in the sourced material.

${ }^{\text {a }}$ The comparison trial rate is calculated as $N$ cases going to trial/( $N$ guilty pleas + cases going to trial).

${ }^{\mathrm{b}}$ Children are those under 18 years. Data include all penetrative offenses (rape, attempted rape, USI) and nonpenetrative offenses (indecent assault and indecency).

c Other outcomes include not proceeded with, dismissed, withdrawn, or defendant failed to appear or died.

${ }^{\mathrm{d}}$ Includes the same offenses as n. b (above) except USI, which applies only to cases with a victim younger than 16 years.

${ }^{\mathrm{e}}$ Victims in rape cases are of all ages, but in USI cases, they are younger than 16 years. 


\section{F. Which Victims Are More Credible?}

A contentious area of rape case handling in law and legal practice is that inferences are drawn about a suspect's culpability, or a defendant's guilt or innocence, that are based on victim-offender relationships, along with a victim's "character," "credibility," and "conduct." Estrich's (1987) analysis of nineteenth- and twentieth-century rape cases (up to the mid-1970s) in the United States shows a general "distrust" toward women victims, particularly those who knew an offender. Such distrust continued, she argued, in the 1970s and 1980s after the introduction of rape law reform.

In a classic early work, Kalven and Zeisel (1966, pp. 249-57) pointed out that in rape trials, a jury does not focus solely on the question of consent. Rather, "it closely, and often harshly, scrutinizes the female complainant and is moved to leniency . . . when there are suggestions of contributory behavior on her part" (p. 249). Such contributory behavior or a victim's "assumptions of risk" include drinking or going home from a bar with the defendant or having been in a previous relationship with the defendant. ${ }^{17}$

Thus, according to these authors, attention to a victim's character and credibility will emerge more often in some cases (simple rape) than in others (aggravated rape). With some exceptions (e.g., Horney and Spohn 1996), few researchers have directly tested this proposition. Rather, they identify elements that distinguish "genuine" from other victims (Spears and Spohn 1996, p. 192) or "traditional" from "nontraditional" rape victims (La Free 1989). Genuine victims are those having a "good" moral character (e.g., no history of drug or alcohol abuse, of previous offending, or of working in the sex industry); who did not engage in risk-taking behavior before the offense (walking alone at night, hitchhiking, at a bar alone, going home with an offender); who screamed and physically resisted an assault; and who reported the offense right away. LaFree distinguishes traditional women who conform to traditional gender roles from those who do not (p. 51). Like Spears and Spohn (1996), he considers two dimensions of a woman's character and behavior in rape cases: general "lifestyle" and reputation and what occurred just before the offense. Traditional rape

\footnotetext{
${ }^{17}$ Kalven and Zeisel (1966) also say that although a jury is likely to acquit a defendant when there is perceived "contributory fault" by the victim, if it has the option of convicting on a lesser offense, it will do so: "The jury's stance is not so much that involuntary intercourse under these circumstances is no crime at all, but rather that it does not have the gravity of rape" (p. 250).
} 
victims dress modestly, are not sexually active outside marriage, and do not work in "disreputable" occupations; and leading up to the offense, they do not engage in risk-taking behaviors (of the sort already noted). ${ }^{18}$

There is an age base to constructions of genuine and traditional victims and "aggravated" and "simple" rape: they apply to adults, not children. As Spears and Spohn (1996) find in analyzing prosecutors' charging decisions, elements of a child's moral character and reputation, or of risk taking, are not relevant. Few child victim cases can be classified as aggravated since most involve a lone person the child knows, without a weapon or serious physical injury. On the basis of their research, the child victims who are believed are those for whom there is a witness to the offense.

However, in adult victim cases, a woman's character and risk taking do affect police, prosecutor, court, and jury decisions (see citations to studies up to the mid-1990s by Horney and Spohn [1996, pp. 135-36]). Believable and credible adult victims have a good moral character and sexual reputation, and they have not engaged in perceived risk-taking behavior before the incident. Credibility is enhanced when the offense is reported right away rather than some time later and when the accused is someone the victim has never met. In addition to these elements are case and evidence factors, which reinforce (or undermine) a complainant's credibility (as well as the ability to positively identify a suspect). They include witness and forensic evidence, physical injury to the victim, and use of force or a weapon.

\section{Questions, Hypotheses, and Doubts}

Our study raises questions about conviction rates and their variability, attrition (or retention) rates at different stages in the legal process, and the factors associated with police and court decisions. They are as follows:

QUESTION 1. With victims' reports to the police as the base, what is the overall rate of conviction (by plea or trial) to any sexual offense and to the original offense?

\footnotetext{
${ }^{18}$ LaFree's terminology of "traditional" and "nontraditional" rape victims differs from how others distinguish traditional and nontraditional rape, with the latter referring to victim-offender relations and offense elements.
} 
QUESTION 2. Do overall conviction rates vary over time, by country, by age of victim, or by type of offense?

QUESTION 3. What are the attrition rates at each stage of the legal process?

QUESTION 4. What is the trial rate and the conviction rate at trial?

QUESTION 5. For those pleading guilty or found guilty, what percentage receive a detention sentence?

QUESTION 6. What factors are associated with police and court decisions at different stages of the legal process?

We examine victims' age, character and credibility, and promptness in reporting the offense; victim-offender relationships; the suspect's criminal history; physical/forensic evidence; victim injury; and use of force or weapon.

In addition, we test claims about the changing nature of rape cases reported to the police and the implications this may have for changes in conviction rates. Our review shows that countries vary as to when legal reform began, in trends of reported rape and sexual assault to the police, and in how courts handle cases. We test relationships that flow logically from these dimensions of law and the legal process. Finally, we test the strength and durability of the factors associated with the real rape construct, as we define it, in adult victim cases. Specifically, we test the degree to which stranger relations, victim character and credibility, and evidence factors are related to police and court decisions. Although we expect these factors to play little or no role in child victim cases, we are interested to determine what factors do play a role. We put forward the following hypotheses.

HYPOTHESIs 1. The overall rate of conviction has decreased over time.

Hypothesis 2. Countries that initiated legal reform earlier (the United States, Australia, and Canada) have higher overall conviction rates than England and Wales and Scotland, which initiated reform later.

Hypothesis 3. Attrition is greatest in England and Wales, where rates of report to the police have steadily increased over time, comparison trial rates are highest, and conviction at trial is low.

Hypothesis 4. The real rape construct is relevant to police and court decisions in adult cases but not in child victim cases.

Hypothesis 1 is derived, in part, from research in England and 
Wales, which suggests that rising rates of reported sexual assault to the police, which likely contain more nontraditional cases (known relations and simple rape), have led to reductions in the conviction rate (Harris and Grace 1999; Kelly 2001). It is supplemented by our ministudy, for which we found a higher share of stranger relations in study samples from the 1970s and 1980s than in those from the 1990s onward.

For hypothesis 2, most commentators say that legal reform has had little or no effect on increasing rates of conviction. However, we might expect some organizational change to have occurred in countries where comprehensive legal reform has been in place for some time, which may facilitate higher conviction rates. It is also possible that just the opposite is occurring. Early reform countries may have increasing rates of victims' reports to the police that are not adequately responded to, which result in lower conviction rates.

Hypothesis 3 is generated from police reports and published court data on trial rates and conviction at trial. In contrast to other countries, England and Wales has seen a sharp increase in reports of sexual assault to the police during the 1990s and continuing into the early 2000s. Such increases have likely put pressure on organizational routines and resources in police departments, which have resulted in greater attrition at this stage of the legal process. In addition, British court data suggest a high trial rate but a low conviction rate at trial. In other countries and especially the United States, a greater share of cases are settled by guilty plea, with a lower trial rate and a higher rate of conviction at trial. For hypothesis 4, we have every reason to suspect that the real rape construct remains relevant in police and court decisions in adult victim cases.

Doubts may be raised by the ambitiousness and scale of this research. Virtually all rape case attrition studies focus on one jurisdiction (a city, state, or country) or perhaps several cities or states. None has examined multiple countries or periods as long as 35 years. None has attempted to relate attrition research findings to trends in published police or court data. Few compare findings from adult and child victim samples or, more generally, explore the role of victims' ages in police and court decisions. There are good reasons why researchers have taken their course of action and not ours. They are better able to specify the legal contexts, organizational constraints, and work group practices in the jurisdictions studied. They are better able to separate samples or exclude cases by victims' ages or offense types (although as we shall see, 
such precision is often lacking in attrition studies). They can be more precise and may have fewer doubts about what they are finding.

In our study, many interpretive doubts flow from using a country level of aggregation, broad time frames, and country- or state-level police and court data that are not strictly comparable. Countries' data may count different things (e.g., rape, USI, both rape and USI, sexual assault), and they may exclude vital clues about legal culture and organizational processes (e.g., the trial rate, conviction at trial, other court outcomes). The attrition studies themselves are not a representative sample of jurisdictions from the five countries but are likely to reflect biases of place (more often urban areas) and researchers' access.

Conviction and attrition rates in rape and sexual assault cases are created from a complex mix of victims' decisions to report certain kinds of cases; police decisions and abilities to locate suspects and proceed with certain cases; and prosecutorial decisions to adjudicate or withdraw certain cases, take pleas, or go to trial. This complexity is occurring within a changing and charged political and social environment in which it is likely that a more heterogeneous set of rape and sexual assault cases are being reported to the police in the last decade or so compared with three decades ago. Comprehensive legal reform may be associated with increasing or decreasing conviction rates, depending on the level of resources, enlightenment, and readiness required for justice officials and members of society to change. Finally, as Frohmann and Mertz (1994) suggest, improving conviction rates is one goal of legal reform; another is changing processes to achieve a more respectful treatment and better understanding of rape victims. Despite these complexities and interpretive doubts, there is much to be gained by exploring broad trends and taking a comparative perspective in understanding the legal response to rape.

\section{Study Methods}

Our search began by identifying all English-language journal articles, book chapters, reports, and books that investigated the police and court handling of sexual offenses in the legal process. The main countries were the United States, Australia, Canada, England and Wales, and Scotland. We would have wanted to include studies from continental Europe written in English, but only two from Scandinavian countries (Helweg-Larsen 1985; Pentillä and Karhumen 1990) turned up in the 
search process. As the research progressed, we decided for comparative purposes to examine only common-law countries; thus, these two studies were dropped. Ultimately, the body of work we are describing is limited to practices in common-law, English-speaking countries of the developed world. The findings may provide a platform for future comparative work on common-law and civil-law countries and in nations of the developing world.

\section{A. Inclusion Criteria and Search Strategies}

Our search considered all published work up to September 1, 2007, with an open start time because we wanted to include the earliest studies. We discovered two types of studies. One is the flow study, which tracks cases through all the stages of the criminal justice system, that is, police, prosecution, and court stages, and presents an overall rate of conviction from report to the police to final court outcome. A second is the snapshot study, which analyzes attrition at one or more stages of the legal process and provides the proportion or number of cases that proceeded past the police or past prosecution or resulted in conviction in court. Most flow studies also examined attrition at each stage of the legal process. We used both to estimate overall rates of conviction and attrition at each stage of the legal process and to identify the factors associated with attrition. Four search strategies were used.

First, we consulted major academic sources (e.g., Bryden and Lengwick 1997; Kelly 2000, 2001; Lievore 2003; Koss 2006; Du Mont and White 2007), government sources and reviews (e.g., HM Crown Prosecution Service Inspectorate 2002; NSW Legislative Council 2002; Queensland Crime and Misconduct Commission 2003; NSW Criminal Justice Sexual Offences Taskforce 2005; South Australia Legislative Review Committee 2005), and bibliographies on legal responses to rape and sexual assault.

Second, we searched online databases for study content and wellknown authors. Databases that covered a range of disciplinary areas were searched, including criminology, law, social science, and health in English-speaking jurisdictions.

Third, we searched government, research center, and victim advocacy Web sites. For each country, Web sites of justice and health departments, leading criminology research organizations (e.g., Australian Institute of Criminology), and victim advocacy Web sites (e.g., National Center for Victims of Crime) were searched. 
Fourth, we reviewed early works on rape and the criminal justice system for citations to other early studies that did not surface in electronic searches.

\section{B. Cases in the Study}

Over 90 published and unpublished studies met our criteria. Upon closer inspection, we found that authors sometimes published the results of the same data set in two or more outlets or that two published studies could be combined as one case in our data set. Thus, the initial number of studies reduced to 75 unique cases. ${ }^{19}$ These are sorted alphabetically by author surname in appendix A (table A1), which lists the study context, offenses analyzed, data collection period, sample size, and type of attrition and conviction data.

Several studies and reports were considered but dropped. Kelly and Regan (2001; see also Regan and Kelly 2003) provided attrition figures supplied by European government departments, but some figures were doubtful or it was unclear how they were generated. Other studies considered but not included are those by Heenan and Murray (2006) and Brown, Hamilton, and O'Neill (2007), who tracked cases from police reports to charging or court proceedings but did not give court outcomes, and Hanly (2007), who focused solely on jury trials. ${ }^{20}$

\section{Assembling the Data Set and Making Estimates}

There were many technical challenges in assembling the data set and estimating conviction and attrition rates. We highlight what we did, but a more detailed explanation is contained in appendix B.

1. Coding the Studies. We developed a coding schedule with qualitative and numerical information. The variables included the study's aim, date and length of data collection, jurisdiction, sample size and selection, offense types studied, age and sex of victims and offenders (when given), the number and percentage of cases at each legal stage (police, prosecution, court, trial), overall conviction rate, factors linked

\footnotetext{
${ }^{19}$ The original list of studies and finalized set are available for those interested. We thought we had identified all the studies meeting our criteria but recently learned that we had overlooked an early U.S. attrition study (McCahill, Meyer, and Fischman 1979). That study's overall conviction rate, reported below, is within 1 percentage point of our estimate for the United States in the early period.

${ }^{20}$ Studies that examined factors associated with police or court outcomes but did not examine conviction or attrition rates were not included (e.g., a well-known study by Kerstetter [1990]).
} 
to police and court decisions, study quality score, and a summary of the major findings.

Study samples were gathered in different ways. Most flow studies drew their samples from cases reported to the police. However, the entry points for some studies of child sexual assault were cases reported to a children's hospital or child protection unit; for adult victims, some drew samples from hospital emergency rooms or sexual assault crisis centers. Problems in sample selection bias, if any, were noted.

Studies varied in clarity and precision. At times, it was not clear what the initial base of cases was (e.g., all reports to the police or a smaller subset) nor at what exact stage of the legal process the official file was obtained. This posed problems in estimating conviction and attrition rates accurately, but each problem was resolved by using a consistent set of rules for including or excluding cases. The character and composition of sexual offenses studied varied, and at times, it was not clear which offenses were studied. This was important to code as accurately as possible because as offense categories move from rape and penetrative offenses to broader categories of sexual assault and all sexual offenses, we can expect to see an increasing rate of conviction. This is apparent in countries' court data (tables 2 and 3 ) and research on youth sex offenses (Daly 2006).

The most frequent flaw in the studies was a lack of detail on victims' ages and inconsistency in defining age ranges. As a result, we could not create discrete age categories. Some studies had victims of all ages, but the authors did not specify the range of ages; in others, the youngest victim age was given, but it ranged from 10 to 18 . We ultimately decided on three categories: "adult only" has victims 16 years and older, "mixed age" has victims of all ages, and "child and youth victim only" has victims under 18 . Although the adult only and child/youth categories overlap a bit (which reflects distinctions at law for age of consent and offender age classifications), this is of less concern than the omnibus mixed age group. There was nothing we could do about this problem: it reflects how researchers have carried out their studies.

2. Estimating Attrition and Conviction. Once a case is reported to the police, there are four major sites of attrition: whether it moves past the police to prosecution (i.e., an arrest is made and charges are laid), whether it moves past prosecution to court (i.e., the case is listed for adjudication in court), whether it remains in court or is dismissed or withdrawn, and whether or not the defendant pleads guilty or is found 
guilty at trial. More detail on the stages of attrition and how each was calculated is shown in appendix B.

A key feature of our study is harmonizing conviction and attrition estimates across studies that have employed differing counting and estimation rules. Appendix B shows how this was accomplished and the rules we used; it describes how we pooled estimates from the flow and snapshot studies to achieve a more stable overall conviction rate and how statistical tests of significance were carried out. We highlight several points. The attrition estimates for the police and prosecutorial stages are somewhat rubbery because administrative practices can vary across and within countries, particularly when there are specialized rape and sexual assault units. We estimate conviction rates in two ways: to any sexual offense and to the original sexual offense. Although some argue that attrition occurs when a conviction is to a less serious sexual offense than that charged (e.g., Kelly 2001, p. 31), we do not define attrition this way. Charge or sentence bargaining is an inevitable feature of the criminal court process, although it may be practiced to a greater degree in some countries than in others.

3. Assessing Study Quality. Studies varied in quality and precision; for this reason, we spent considerable time determining whether they should be weighted differently. Although the literature on study quality focuses mainly on meta-analysis and randomized experiments (e.g., Farrington 2003), this was not applicable to our review. Rather, drawing from Khan et al. (2001, p. 5), we are analyzing a set of "case studies." Appendix B describes a study quality score and conviction and attrition results with an unweighted sample and two types of weighted samples. There were nil or negligible differences between the three samples; thus, we use the unweighted sample.

\section{Findings on Conviction, Attrition, and Factors Affecting Outcomes}

Of the 75 study cases, about half (48 percent) are from the United States (see table 4, col. 1). Over half (53 percent) analyze penetrative offenses only (rape, attempted rape, and USI); the rest analyze a broader array of sexual offenses. Over half (54 percent) have victims of mixed ages; 17 percent, adults only; and 29 percent, child and youth victims only. In an analysis not shown in the table, we found that a much higher share of child or youth victim cases were associated with 
TABLE 4

Description of the Rape Attrition Study Sample

\begin{tabular}{|c|c|c|c|c|}
\hline \multirow{2}{*}{ Country: } & \multicolumn{2}{|c|}{$\begin{array}{c}\text { All Cases: } \\
\text { Percent }(N) \\
(1)\end{array}$} & \multicolumn{2}{|c|}{$\begin{array}{c}\text { Cases with } \\
\text { an Overall } \\
\text { Conviction } \\
\text { Rate: }^{\mathrm{a}} \\
\text { Percent }(N) \\
\text { (2) }\end{array}$} \\
\hline & & & & \\
\hline United States & 48 & $(36)$ & 41 & $(27)$ \\
\hline Australia & 23 & $(17)$ & 25 & $(16)$ \\
\hline Canada & 13 & $(10)$ & 15 & $(10)$ \\
\hline England and Wales & 12 & (9) & 14 & (9) \\
\hline Scotland & 4 & (3) & 5 & (3) \\
\hline Total & 100 & $(75)$ & 100 & $(65)$ \\
\hline \multicolumn{5}{|l|}{ Data period: } \\
\hline Early period: $1970-89$ & 51 & $(38)$ & 52 & $(34)$ \\
\hline Later period: $1990-2005$ & 49 & $(37)$ & 48 & (31) \\
\hline \multicolumn{5}{|l|}{ Victims: } \\
\hline Adult only $(16+)$ & 17 & $(13)$ & 14 & (9) \\
\hline Mixed age & 54 & $(40)$ & 58 & (38) \\
\hline Child/youth victims only $(<18)$ & 29 & $(22)$ & 28 & (18) \\
\hline \multicolumn{5}{|l|}{ Type of offense: } \\
\hline Rape and penetrative offenses & 53 & $(40)$ & 52 & (34) \\
\hline All sexual offenses ${ }^{\mathrm{b}}$ & 47 & $(35)$ & 48 & (31) \\
\hline \multicolumn{5}{|l|}{$\begin{array}{l}\text { Stages of attrition in the criminal } \\
\text { justice system: }{ }^{c}\end{array}$} \\
\hline Police & 49 & $(36)$ & & \\
\hline Prosecution & 54 & $(40)$ & & \\
\hline Court & 81 & $(60)$ & & \\
\hline Trial & 49 & $(37)$ & & \\
\hline Sentencing & 28 & $(21)$ & & \\
\hline
\end{tabular}

a Pooled sample estimates come from the flow studies $(N=38)$ and a portion of the snapshot studies $(N=27)$ (excludes outlier case 59).

${ }^{\mathrm{b}}$ Includes penetrative, touch, and no touch sexual offenses.

${ }^{c}$ The percentages add to greater than 100 because a study may look at several stages of the criminal process (excludes outlier case 59).

a broader set of sexual offenses (94 percent) compared to mixed age victim (32 percent) or adult only victim (22 percent) cases.

The year of data gathering ranges from 1970 to 2005. Estimates cluster in two phases: earlier (1970-89 data) and later (1990-2005 data). These two phases also correspond to older and newer ways of researching sexual victimization. Thus, it seemed logical to use these indicators to draw a temporal line in our analysis. These earlier and later phases do not coincide with pre- and postlegal reform because all 
five countries had some type of legal reform by the end of the 1980s, although some had gone substantially further than others. Rather, the more recent period (1990 forward) can be viewed as a time when legal reform matured, when there was a more developed consciousness by victims (and victim support groups) of expanding definitions of rape, and when more research attention was given to sample surveys of physical and sexual victimization, using more sensitive methods. Studies from the earlier period are mainly from the United States (63 percent), whereas those from the later period have a better mix (United States, 32.5 percent; Australia, 35 percent; Canada, 11 percent; England and Wales, 16 percent; and Scotland, 5.5 percent).

Other descriptors, not shown in the table, are as follows. Data gathering ranged from 2 months to 12 years; in most cases, there is a $12-$ 24-month time frame. Australia and the United States are governed by state-level legislation. Most of the Australian cases are from New South Wales (47 percent) or Victoria (29 percent); for the United States, the jurisdictions are more dispersed, often with multiple states or cities studied. ${ }^{21}$ Canadian criminal law is the same across the provinces, although most attrition studies are from Manitoba (40 percent) and British Columbia (30 percent).

\section{A. Overall Conviction Rates}

Table 5 displays the overall rates of conviction for any sexual offense and for the original sexual offense, based on estimates generated from the flow and snapshot studies. ${ }^{22}$ For the averages across all countries (top rows), it can be seen that across three decades, the average (mean) overall conviction rate is 15 percent, and conviction to the original offense charged by the police is 9 percent. ${ }^{23}$ When we disaggregate by time period, the overall rate of conviction for any sexual offense in the early period is 18 percent but reduces significantly to 12.5 percent in

\footnotetext{
${ }^{21}$ For the United States, the majority of the studies were conducted in states in the Northeast, Midwest, Southwest, and West. No studies were from states in the South.

${ }^{22}$ For all estimates of conviction and stage attrition, the decision was made to exclude case 59 (Patterson 2005) because it tested a special emergency room program (the SANE program) that produced unusually high rates of conviction; however, this study is included in the analysis of factors associated with attrition.

${ }^{23}$ Here and in all tables, we report all conviction and stage attrition rates to 0.5 percent. Results that were xx. 3 percent or less were rounded down; results that ranged from xx.4 to xx.6 percent were reported as xx. 5 percent; and results that were xx.7 percent or up were rounded up.
} 
TABLE 5

Combined Overall Rates of Conviction from Flow and Snapshot Studies by Country

\begin{tabular}{|c|c|c|c|c|c|}
\hline & $\begin{array}{c}1970-2005 \\
\text { (1) }\end{array}$ & $\begin{array}{c}1970-2005 \\
\text { (2) }\end{array}$ & $\begin{array}{c}1970-89 \\
(3)\end{array}$ & $\begin{array}{c}1990-2005 \\
(4)\end{array}$ & $\begin{array}{c}\text { Difference } \\
(\%) \\
(5)\end{array}$ \\
\hline & \multicolumn{5}{|c|}{ Conviction to } \\
\hline & $\begin{array}{c}\text { Any Sexual } \\
\text { Offense }\end{array}$ & $\begin{array}{l}\text { Original } \\
\text { Sexual } \\
\text { Offense }\end{array}$ & \multicolumn{3}{|c|}{ Any Sexual Offense } \\
\hline $\begin{array}{l}\text { All countries } \\
\text { Range (\%) }\end{array}$ & $\begin{array}{c}N=65 \\
7-35\end{array}$ & $\begin{array}{c}N=22 \\
5-19\end{array}$ & $\begin{array}{l}N=34 \\
11-35\end{array}$ & $\begin{array}{c}N=31 \\
7-19\end{array}$ & \\
\hline \multirow{2}{*}{ Mean (\%) } & 15 & 9 & 18 & 12.5 & $-5.5^{\mathrm{a}}$ \\
\hline & & & \multicolumn{3}{|c|}{ Original Sexual Offense } \\
\hline $\begin{array}{c}\text { All countries } \\
\text { Range (\%) } \\
\text { Mean (\%) }\end{array}$ & & & $\begin{array}{c}N=11 \\
6-19 \\
11\end{array}$ & $\begin{array}{c}N=11 \\
5-10 \\
6.5\end{array}$ & $-4.5^{\mathrm{b}}$ \\
\hline Mean (\%) & $\begin{array}{c}\text { Any Sexual } \\
\text { Offense }\end{array}$ & $\begin{array}{l}\text { Original } \\
\text { Sexual } \\
\text { Offense }\end{array}$ & \multicolumn{3}{|c|}{ Any Sexual Offense } \\
\hline United States & $N=27$ & $N=6$ & $N=20$ & $N=7$ & \\
\hline Range (\%) & $7-18$ & $6-13$ & $7-17$ & $11-18$ & \\
\hline Mean (\%) & 13 & 8 & $13^{\mathrm{c}}$ & 14 & +1.0 \\
\hline Australia & $N=16$ & $N=7$ & $N=4$ & $N=12$ & \\
\hline Range (\%) & $7-20$ & $6-12$ & $14-20$ & $7-17$ & \\
\hline Mean (\%) & 13 & 10.5 & 17 & 11.5 & $-5.5^{\mathrm{a}}$ \\
\hline Canada & $N=10$ & $N=1$ & $N=6$ & $N=4$ & \\
\hline Range (\%) & $11-32$ & 9 & $19-32$ & $11-17$ & \\
\hline Mean (\%) & 21 & $\ldots$ & 26.5 & 14 & $-12.5^{\mathrm{a}}$ \\
\hline England and Wales & $N=9$ & $N=6$ & $N=3$ & $N=6$ & \\
\hline Range (\%) & $7-35$ & $5-19$ & $11-35$ & $7-12$ & \\
\hline Mean (\%) & 15 & 8.5 & 24 & 10 & $-14.0^{\mathrm{a}}$ \\
\hline Scotland $^{\mathrm{d}}$ & $N=3$ & $N=2$ & $N=1$ & $N=2$ & \\
\hline Range (\%) & $13-19$ & $10-15$ & 18 & $13-19$ & \\
\hline Mean (\%) & 17.5 & 14 & $\ldots$ & 17.5 & $\ldots$ \\
\hline Four-country ${ }^{\mathrm{e}}$ & $N=38$ & $N=16$ & $N=14$ & $N=24$ & \\
\hline Range (\%) & $7-35$ & $5-19$ & $11-35$ & $7-19$ & \\
\hline Mean (\%) & 16.5 & 9.5 & 23 & 12 & $-11.0^{\mathrm{a}}$ \\
\hline
\end{tabular}

a Significant drop in convictions from the early to the later period, $p<.01$.

${ }^{\mathrm{b}}$ Significant drop in convictions from the early to the later period, $p<.05$.

${ }^{c}$ The U.S. conviction rate is significantly lower than the four-country rate, $p<.05$.

${ }^{\mathrm{d}}$ Like all the estimates, the Scottish estimates are based on an average of the snapshot and flow studies that gives more weight to the flow studies. See app. table B2.

e Australia, Canada, England and Wales, and Scotland. 
the later period. The corresponding figures for conviction to the original sexual offense are 11 percent and 6.5 percent, respectively.

For conviction rates by country across time (cols. 1 and 2), the mean rates are somewhat lower for the United States (13 percent), Australia (13 percent), and England and Wales (15 percent) compared with Scotland (17.5 percent, an estimate based on only three studies) ${ }^{24}$ and Canada (21 percent). These averages belie a more complex story of variability by country and time period, which is shown in table 7 below. This is visualized in two ways. Figure 2 shows overall conviction rates for all studies as a scatter plot. Figure 3 gives the best-fitting line by country (excluding Scotland, which has too few cases). For the United States, the overall conviction rates are nearly identical in the earlier and later time periods (13 and 14 percent, respectively). By contrast, the rates for Australia, Canada, England and Wales, and Scotland (a four-country average) decreased significantly: from 23 to 12 percent. $^{25}$ The generally low rate of conviction for the United States, although unusual in the earlier period, is typical of the rates for England and Wales, Canada, and Australia in the later period. From 1990 onward, there is less dispersion in conviction rates for the five countries.

Drawing from Kelly's (2001) analysis, several commentators have noted a large drop in conviction rates in England and Wales (e.g., Lievore 2004; Koss 2006). On the basis of our analysis, there is a considerable drop, but how much of a drop depends on which studies are used and what is defined as the "conviction rate" (i.e., conviction to any sexual offense or to the original sexual offense). Some may rely only on the inflated statistic initially reported by Grace, Lloyd, and Smith (1992) of 34 percent (since corrected by the authors to 27 percent; see Harris and Grace 1999) and San Lazaro, Steele, and Donaldson's (1996) estimate of 35 percent. However, another British study, which is on the cusp of the early and later period as we define it (Gregory and Lees 1996; data period midpoint 1989), found an 11 percent conviction rate. For the earlier period, then, we calculate the average attrition rate from three British studies to be 24 percent. Because the United States and Canada have more studies from the earlier

\footnotetext{
${ }^{24}$ The Scottish estimate of 17.5 percent is an average of one snapshot and two flow studies that gives more weight to the flow studies; it is not a straight arithmetic average. See app. table B2.

${ }^{25}$ We include Scotland in this average, although its pattern of conviction differs from that of the other three countries. If Scotland is excluded, a three-country average is nearly the same: 23.5 percent and 11.5 percent in the early and later period, respectively.
} 


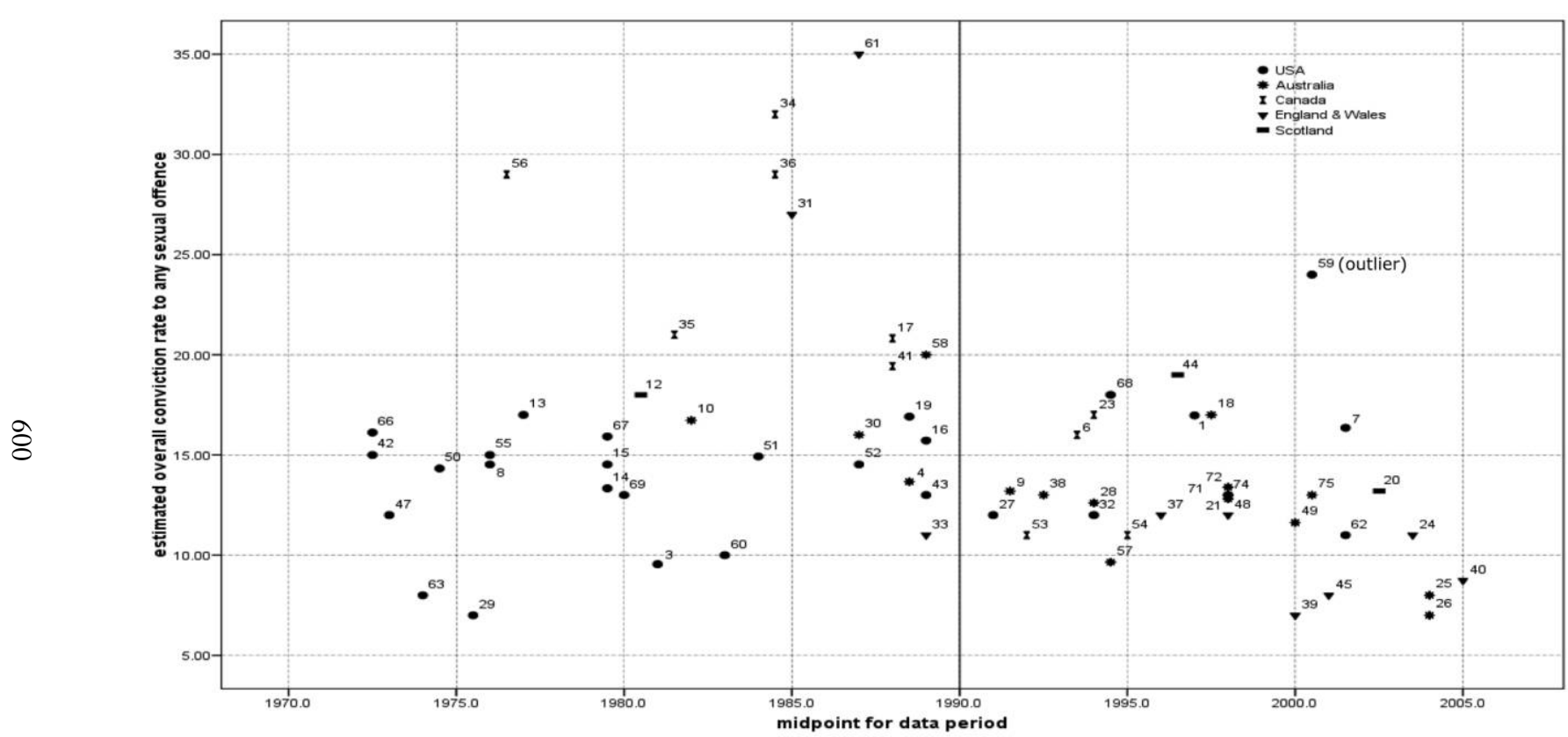

FIG. 2.-Estimated overall conviction rate to any sexual offense: each study's outcome 


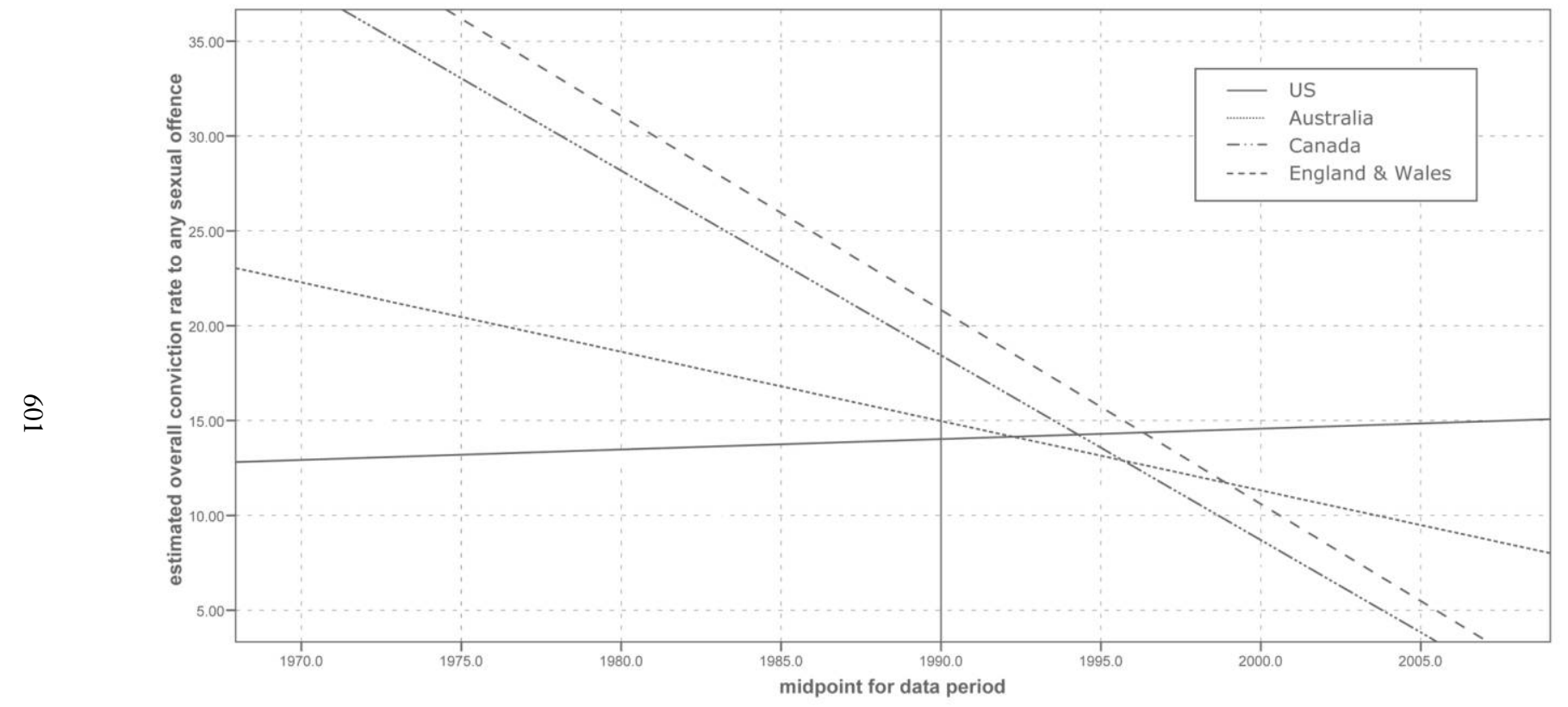

FIG. 3.-Estimated overall conviction rate to any sexual offense: best-fitting line by country 
period, we can be somewhat more confident of temporal trends from these two countries.

In summary, overall rates of conviction for rape and sexual assault have remained the same in the United States (13-14 percent over time). ${ }^{26}$ Studies from Canada show a significant decrease in rates of conviction from the early and later periods (from 26.5 to 14 percent). Those from Australia also show a significant decline (from 17 to 11.5 percent), ${ }^{27}$ although not as large as Canada's. For England and Wales, overall conviction rates have dropped significantly, from 24 to 10 percent. Averages for Scotland remain stable over time (18 and 17.5 percent), but there are just three estimates. Countries' average conviction rates are more dispersed in the earlier period (ranging from 13 to 26.5 percent) than in the later period (10-14 percent, excluding Scotland).

For victim's age and types of offense (table 6), across the three decades, overall rates of conviction are somewhat higher in samples of child or youth victims (18.5 percent) than those of mixed age (15 percent) or adults only (12 percent). Over time, there is a significant drop in conviction for mixed age (16.5 to 13 percent) and child or youth victim cases (22 to 13 percent). Significant differences in conviction are evident by type of offense, both across time and in the more recent time period, with an expectably lower rate for rape and penetrative offenses (13 percent), compared to a broader range of sexual offenses (17 percent).

\section{B. Attrition by Stage of the Legal Process}

Data from the flow and snapshot studies were joined to estimate attrition at each stage of the criminal process (table 7). Across all time periods and five countries, after cases are reported to the police, 65 percent are dropped; in other words, 35 percent proceed past the police to the prosecution. From the prosecutor's desk, 66 percent proceed to court. Once in court, 66 percent of cases are convicted of any sexual offense and 42 percent are convicted of the original sexual offense. On average, 38 percent of cases go to trial, and 58.5 percent are found guilty at trial. Of those convicted, 60 percent are sentenced to incarceration, but we do not know what percentage actually served time

${ }^{26}$ The overall rate of conviction in McCahill, Meyer, and Fischman (1979) was 12 percent.

${ }^{27}$ In Triggs et al.'s (2009) study of adult victim "sexual violation" cases in 2005-7 for New Zealand, the overall rate of conviction to any sexual offense was 14 percent, which falls within the 10-14 percent range found in our study. 
Rape and Attrition in the Legal Process

TABLE 6

Combined Overall Rates of Conviction from Flow and Snapshot Studies by Victim Age and Offense Type

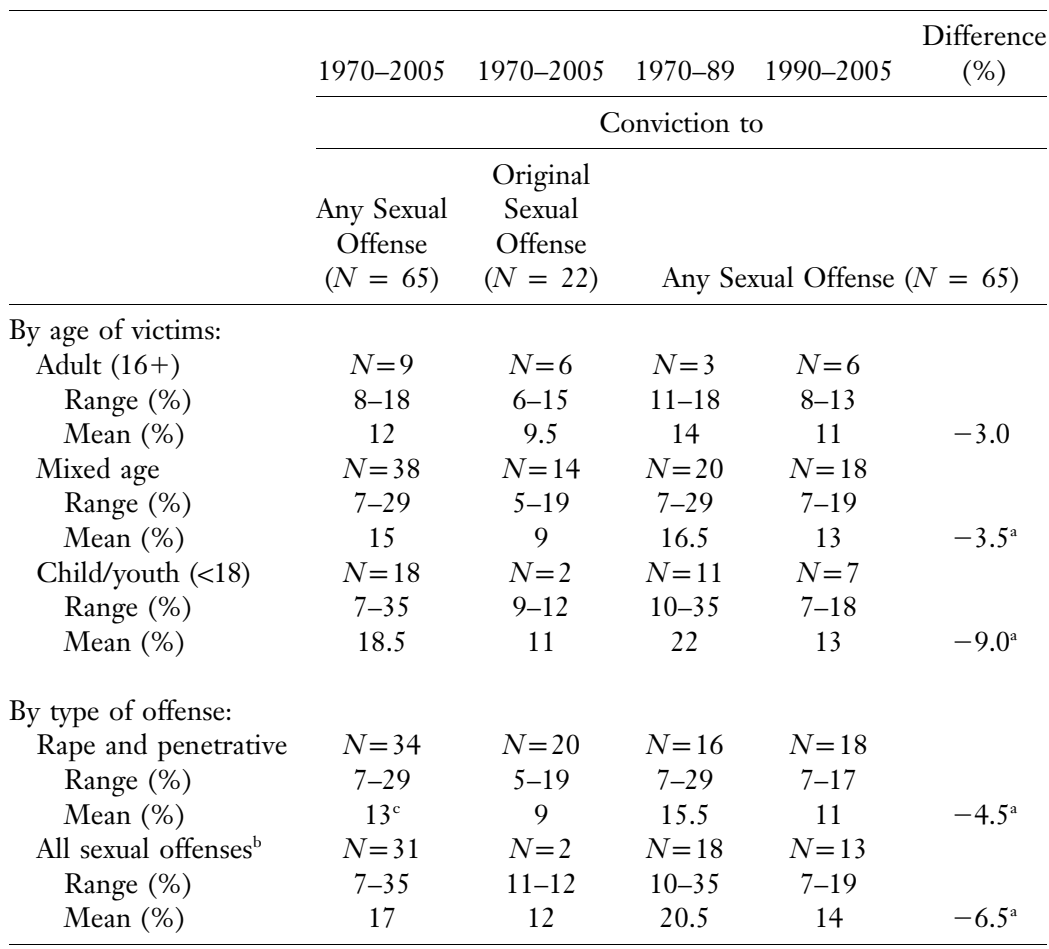

${ }^{a}$ Significant drop in convictions from the early to the later period, $p<.05$.

${ }^{\mathrm{b}}$ Includes penetrative offenses, touch, and no touch sexual offenses.

${ }^{\mathrm{c}}$ The conviction rate for rape and penetrative offenses is significantly lower than for all sexual offenses, $p<.05$.

because studies do not report suspended or partially suspended sentences. The average across time and countries for our measure of "case flow into court" (the product of police and prosecutor decisions) is 23 percent.

Table 8 gives selected findings by age of victim and offense type across time. Case flow into court is higher for child or youth cases (26 percent) than for mixed age ( 23 percent) or adult cases $\left(21\right.$ percent).$^{28}$ Of cases in court, conviction is significantly less likely in samples of

\footnotetext{
${ }^{28}$ We use "case flow into court" here and in table 9 because, in part, the police and prosecutor figures are variably measured and in part to simplify presentation of the data.
} 
TABLE 7

Proportion of Cases That Proceed Past the Different Stages of the Criminal Justice Process across All Countries and Time Periods

\begin{tabular}{lcc}
\hline & \multicolumn{2}{c}{ Cases That Proceed } \\
\cline { 2 - 3 } Criminal Justice System Stage $^{\mathrm{a}}$ & Range $(\%)$ & Mean (\%) \\
\hline $\begin{array}{l}\text { Of cases reported to police, those } \\
\text { referred for prosecution }(N=36)\end{array}$ & $15-56$ & $35^{\mathrm{b}}$ \\
$\begin{array}{l}\text { Of cases referred for prosecution, } \\
\text { those referred to court }(N=40)\end{array}$ & $33-87$ & 66 \\
$\begin{array}{l}\text { Of cases in court, those convicted of } \\
\text { any sex offense }(N=60)^{\mathrm{c}}\end{array}$ & $35-88$ & 66 \\
$\begin{array}{l}\text { Of cases in court, those convicted of } \\
\text { original sex offense }(N=21)^{\mathrm{c}}\end{array}$ & $25-67$ & 42 \\
$\begin{array}{l}\text { Of cases in court, those going to } \\
\text { trial }(N=33)\end{array}$ & $11-75$ & 38 \\
$\begin{array}{l}\text { Of trial cases, those found guilty at } \\
\text { trial of any sex offense }(N=37)\end{array}$ & $27-94$ & 58.5 \\
$\begin{array}{l}\text { Of cases sentenced, }{ }^{\mathrm{c}} \text { those with } \\
\text { incarceration imposed }(N=21)^{\mathrm{d}}\end{array}$ & $22-97$ & 60 \\
\hline
\end{tabular}

a The N's in parentheses refer to the number of studies that provided information at each stage considered.

${ }^{\mathrm{b}}$ Case flow into court: 23 percent ( 35 percent $\times 66$ percent).

${ }^{\mathrm{c}}$ Includes those found guilty at trial and those who pleaded guilty.

${ }^{\mathrm{d}}$ Incarceration imposed includes both suspended and nonsuspended sentences.

adults only (53 percent) compared to those of mixed ages (67 percent) or children or youths (70.5 percent). Trial rates are significantly lower in child or youth cases than in mixed age or adult cases, but conviction at trial is similar across age groups. The likelihood of an incarceration penalty is significantly lower in child or youth cases ( 49.5 percent) than in adult cases ( 73 percent). The findings for age are linked to the types of offenses analyzed. Rape and penetrative offenses have a significantly higher rate of cases going to trial ( 43 percent) than the broader category of all sexual offenses ( 29 percent), and they attract a higher rate of detention. The trial and detention rates for adult and mixed age victims are based largely on analyses of rape and penetrative offenses only, whereas those for child or youth victims are based on a wider set of sexual offenses. We acknowledge that these analyses by victim's age and offense type are not entirely satisfactory: except for adult only and rape and penetrative offenses only, the age and offense categories are not discrete but overlapping. Future research needs to take better care in coding and analyzing victims' ages and types of offenses. 
TABLE 8

Rates of Case Flow into Court, Court Conviction, and Sentencing Outcome by Victim Age and Offense Type (\%)

\begin{tabular}{|c|c|c|c|c|c|}
\hline & $\begin{array}{l}\text { Flow into } \\
\text { Court }\end{array}$ & $\begin{array}{c}\text { Court } \\
\text { Conviction } \\
\text { to Any } \\
\text { Sex Offense }\end{array}$ & $\begin{array}{l}\text { Cases } \\
\text { Going } \\
\text { to Trial }\end{array}$ & $\begin{array}{c}\text { Trial } \\
\text { Conviction } \\
\text { to Any Sex } \\
\text { Offense }\end{array}$ & $\begin{array}{l}\text { Incarceration } \\
\text { Imposed }\end{array}$ \\
\hline \multicolumn{6}{|l|}{ By age of victim: } \\
\hline Adult $(16+)$ & & $N=9$ & $N=7$ & $N=8$ & $N=5$ \\
\hline Range & & $35-76$ & $18-74$ & $27-94$ & $46-97$ \\
\hline Mean & 21 & $53^{\mathrm{a}}$ & $46.5^{\mathrm{b}}$ & 55 & 73 \\
\hline Mixed age & & $N=34$ & $N=14$ & $N=15$ & $N=5$ \\
\hline Range & & $43-88$ & $15-75$ & $38-89$ & $48-88$ \\
\hline Mean & 23 & 67 & 43 & 59 & 69.5 \\
\hline Child/youth $(<18)$ & & $N=17$ & $N=12$ & $N=15$ & $N=11$ \\
\hline Range & & $44-85$ & $11-48$ & $36-87$ & $22-69$ \\
\hline Mean & 26 & 70.5 & 28 & 60 & $49.5^{\mathrm{c}}$ \\
\hline \multicolumn{6}{|l|}{ By type of offense: } \\
\hline Rape and penetrative & & $N=32$ & $N=21$ & $N=22$ & $N=6$ \\
\hline Range & & $35-88$ & $15-75$ & $31-94$ & $48-97$ \\
\hline Mean & 21 & 64 & $43^{\mathrm{d}}$ & 59 & 73 \\
\hline All sexual offenses ${ }^{\mathrm{e}}$ & & $N=28$ & $N=12$ & $N=15$ & $N=15$ \\
\hline Range & & $42-87$ & $11-48$ & $27-87$ & $22-89$ \\
\hline Mean & 25 & 68 & 29 & 57.5 & 55 \\
\hline
\end{tabular}

${ }^{a}$ Rate for adult cases is significantly lower than that for mixed age and child/youth cases, $p<.05$.

${ }^{\mathrm{b}}$ Rate for adult cases is significantly higher than that for child/youth cases, $p<.05$.

${ }^{\mathrm{c}}$ Rate for child/youth cases is significantly lower than that for mixed age and adult cases, $p<.05$.

${ }^{\mathrm{d}}$ Rate for penetrative offenses is significantly higher than that for all sexual offenses, $p<.05$.

${ }^{\mathrm{e}}$ Includes penetrative offenses, touch, and no touch sexual offenses.

\section{Attrition at Police and Court Stages by Country and over Time}

Table 9 arrays the stage outcomes by time and country, and it shows that the story of attrition is again more complex than one average across one time period or place. We reiterate that these estimates are averages derived from the available body of research studies, not from a sample of jurisdictions. For all countries combined, there is a reduction in case flow into court from the early to the later period (from 26 to 20 percent); this arises from significant reductions in the rate at which cases proceed past the police and prosecution into court. This average masks important country differences.

For the United States, there is no change over time in the case flow 
TABLE 9

Rates of Case Flow into Court, Court Conviction, and Sentencing Outcome by Time and Country (\%)

\begin{tabular}{|c|c|c|c|c|c|c|c|c|c|c|}
\hline & \multicolumn{2}{|c|}{$\begin{array}{c}\text { Flow into } \\
\text { Court }\end{array}$} & \multicolumn{2}{|c|}{$\begin{array}{l}\text { Court Convic- } \\
\text { tion to Any Sex } \\
\text { Offense }\end{array}$} & \multicolumn{2}{|c|}{$\begin{array}{c}\text { Cases Going to } \\
\text { Trial }\end{array}$} & \multicolumn{2}{|c|}{$\begin{array}{l}\text { Trial Conviction } \\
\text { to Any Sex } \\
\text { Offense }\end{array}$} & \multicolumn{2}{|c|}{$\begin{array}{l}\text { Incarceration } \\
\text { Imposed }\end{array}$} \\
\hline & $1970-89$ & $\begin{array}{l}1990- \\
2005\end{array}$ & $1970-89$ & $\begin{array}{l}1990- \\
2005\end{array}$ & 1970-89 & $\begin{array}{l}1990- \\
2005\end{array}$ & $1970-89$ & $\begin{array}{l}1990- \\
2005\end{array}$ & $1970-89$ & $\begin{array}{l}1990- \\
2005\end{array}$ \\
\hline $\begin{array}{l}\text { All countries } \\
\text { Mean }\end{array}$ & 26 & 20 & $\begin{array}{c}N=32 \\
69.5\end{array}$ & $\begin{array}{c}N=28 \\
62^{\mathrm{b}}\end{array}$ & $\begin{array}{c}N=14 \\
34\end{array}$ & $\begin{array}{c}N=19 \\
41\end{array}$ & $\begin{array}{c}N=15 \\
64\end{array}$ & $\begin{array}{c}N=22 \\
54.5\end{array}$ & $\begin{array}{c}N=11 \\
63\end{array}$ & $\begin{array}{c}N=10 \\
57\end{array}$ \\
\hline \multicolumn{11}{|l|}{ Countries: ${ }^{a}$} \\
\hline United States & & & $N=18$ & $N=5$ & $N=8$ & $N=4$ & $N=9$ & $N=6$ & $N=7$ & $N=3$ \\
\hline Mean & 20 & 19 & 69 & $82^{\mathrm{b}}$ & 32.5 & 20 & 68.5 & $82^{\mathrm{b}}$ & 62.5 & 77 \\
\hline Australia & & & $N=4$ & $N=12$ & $N=3$ & $N=9$ & $N=3$ & $N=10$ & $N=2$ & $N=5$ \\
\hline Mean & 20.5 & 20 & 74 & $61^{c}$ & 36 & 45 & 60 & $41^{c}$ & 52 & 41 \\
\hline Canada & & & $N=6$ & $N=4$ & $N=2$ & $N=0$ & $N=2$ & $N=0$ & $N=2$ & $N=2$ \\
\hline Mean & 35 & $26^{\mathrm{c}}$ & 72 & $53^{\mathrm{c}}$ & 31.5 & $\ldots$ & 62 & $\ldots$ & 74.5 & 65.5 \\
\hline England and Wales & & & $N=3$ & $N=6$ & $N=0$ & $N=5$ & $N=0$ & $N=5$ & $N=0$ & $N=0$ \\
\hline Mean & 34 & $17^{\mathrm{c}}$ & 68 & 57 & $\ldots$ & 51 & $\ldots$ & 46 & $\ldots$ & $\ldots$ \\
\hline
\end{tabular}

${ }^{a}$ Rates for Scotland are not shown because there are too few cases for each time period. Range of conviction rates is shown in table 5 .

${ }^{\mathrm{b}}$ Rates for the later period are significantly higher than those for the early period; $p<.05$ for court, $p<.10$ for trial.

${ }^{\mathrm{c}}$ Rates for the later period are significantly lower than those for the early period, $p<.05$. 
into court (about 20 percent in both periods) but a significant increase in conviction to any sexual offense once cases are in court (from 69 to 82 percent). The rate at which cases go to trial has declined from the early to the later period ( 32.5 to 20 percent), and the rate of conviction at trial has increased significantly (68.5 to 82 percent). Canada evinces a different pattern: a significant decrease in case flow into court, although it remains relatively high (from 35 to 26 percent), and a significant drop in conviction once cases are in court (from 72 to 53 percent). (There are too few studies to calculate trial rates or convictions at trial for Canada.) The pattern is different, yet again, for Australia. In the earlier period, the flow into court, court conviction, and trial rates and outcomes are comparable to those of the United States. Yet, in the later period, there is a significant decrease in conviction once cases are in court (from 74 to 61 percent). The rate of cases going to trial increases somewhat (from 36 to 45 percent), but the rate of conviction at trial drops significantly (60 to 41 percent). ${ }^{29}$

The pattern for England and Wales is similar to Canada's, although its reduction in case flow into court is more dramatic, dropping significantly from 34 to 17 percent. Data not shown in the table show that this drop is caused mainly by a significant reduction in cases proceeding past the police (from 45 to 27 percent), more so than a reduction in cases proceeding past prosecution into court (from 75 to 63 percent). Once cases are in court, the rate of conviction declines from the early to the later period ( 68 to 57 percent). For the later period, the trial rate and conviction at trial are similar to Australia's. ${ }^{30}$

In summary, studies from the United States and Australia show a stable pattern of high rates of attrition at the police and prosecution stages over two time periods (80 percent of cases dropped). However, rates of court conviction have increased significantly in the United States but decreased significantly in Australia. Canada has a relatively high case flow into court; however, this has decreased significantly over time, and court conviction has dropped sharply. For England and Wales, case flow into court has decreased significantly, and as in Aus-

${ }^{29}$ The figures for Australia are nearly identical to those reported in Johnson, Ollus, and Nevala $(2008$, p. 148) for Australia from the IVAWS project: of nonpartner sexual and physical violence cases reported to the police, 23 percent resulted in charges laid (case flow into court); once in court, 63 percent resulted in conviction. The findings are based on what victims recalled during an interview.

${ }^{30}$ For England and Wales, the later period estimate of conviction at trial from our attrition study (46 percent) is considerably better than that given in British court data for 2005 (29 percent; see table 2 above). 
Kathleen Daly and Brigitte Bouhours

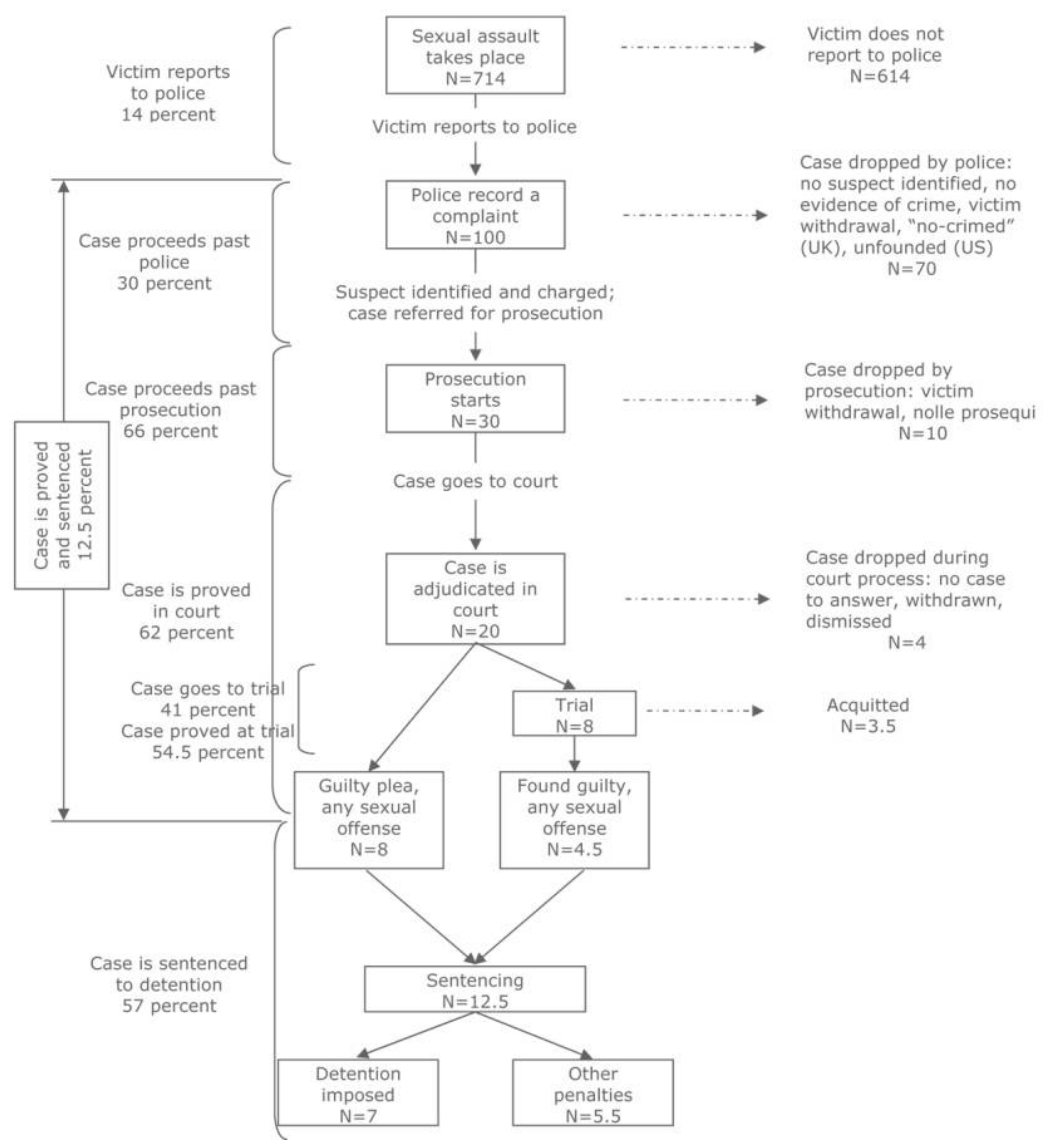

FIG. 4.-The journey of 100 cases reported to police, five countries, 1990-2005

tralia and Canada, court conviction has declined, although not as sharply.

D. The fourney of 100 Cases Reported to the Police

A staple item in the rape attrition literature is a chart displaying the journey of 100 cases reported to the police. This is constructed from a selected set of studies, typically from one country, and often with little attention to the years of data gathering. Now that we are aware of country and temporal variation, it will be difficult to construct just one journey. Figure 4 illustrates the attrition process for the five countries combined in the later period. 
The largest source of attrition is a victim's decision to report the assault to the police or not, with 14 percent on average reporting offenses. For every 100 sexual offenses reported, there are over 600 instances of sexual victimizations not reported. Of 100 reported cases, 70 do not go further than the police stage. The reasons are many: the inability to identify or locate a suspect, victims' withdrawing complaints, and police judgments that the case will be difficult to prosecute for a range of reasons. Once the case has been referred to the prosecutor's office, the rate of attrition decreases. About one-third of cases are dropped before reaching court because prosecutors have doubts of securing a conviction at trial, or a victim is unwilling or unable to continue as a witness, among other reasons. Of the 100 reported cases, 20 are adjudicated in court. Of cases in court, eight go to trial, eight are settled by guilty plea to the same or less serious offense, and four are withdrawn or dismissed. Just over half the trial cases are convicted of a sexual offense. Of 100 cases reported to the police, 12.5 percent are convicted of a sexual offense.

\section{E. Factors in Police, Prosecutorial, and Court Outcomes}

Of the 75 studies, 43 (57 percent) analyzed one or more factors associated with police or prosecutorial or court decisions to drop cases or proceed with them, and 10 of the 43 were of child or youth victims only. Typically, the studies coded information in police, prosecution, and court files. It is unlikely that any factor was used in arguments in open court, although this was not explicitly mentioned. We sought to determine if the set of 75 studies differed along key variables from the 43 that analyzed factors. Our analyses revealed no differences in conviction and attrition rates; thus, we are satisfied that our results can be generalized.

1. Coding the Factors. The nine factors studied were constructions of the victim and the offense (age, sex, character and credibility, promptness in reporting, and victim-offender relations); the suspect's background (criminal history); and strength of evidence (forensic and witness evidence, victim injury, suspect's use of force or weapon). ${ }^{31}$ Table 10 lists the factors, their definition and content, and coding de-

${ }^{31}$ We did not analyze the impact of racial and ethnic classifications of victims or offenders on outcomes. Eleven studies (all from the United States) presented data about the race/ethnicity of a victim or offender, but the effects on outcomes were not recorded in a comparable manner. Sex is relevant to studies of child or youth victims but not to other age groups. 
TABLE 10

Factors Related to Police and Prosecution/Court Decisions: Definitions, Coding, and Distributions

\begin{tabular}{|c|c|c|c|c|}
\hline $\begin{array}{l}\text { Factor } \\
\text { Factors relating to the victim } \\
\text { and the construction of the } \\
\text { offense: }\end{array}$ & \multicolumn{4}{|c|}{$\begin{array}{l}\text { Percent of } \\
\text { Studies with } \\
\text { Factor }^{\mathrm{a}}\end{array}$} \\
\hline Victim's age & $\begin{array}{l}\text { Age of victims to compare outcome for } \\
\text { younger or older victims }\end{array}$ & $\begin{array}{l}\mathrm{A} / \mathrm{MA} \\
\mathrm{CY}\end{array}$ & $\begin{array}{r}79 \\
100\end{array}$ & $\begin{array}{l}\text { All studies: age or age range in years as re- } \\
\text { ported in study }\end{array}$ \\
\hline Victim's sex & $\begin{array}{l}\text { Victim's sex (child/youth only) to deter- } \\
\text { mine if this matters }\end{array}$ & $\begin{array}{l}\mathrm{A} / \mathrm{MA} \\
\mathrm{CY}\end{array}$ & $\begin{array}{r}0 \\
60\end{array}$ & $\begin{array}{l}\text { Adult and mixed age: not studied } \\
\text { Child/youth only: sex of victim as reported } \\
\text { in studies }\end{array}$ \\
\hline $\begin{array}{l}\text { Victim's good character and } \\
\text { credibility }\end{array}$ & $\begin{array}{l}\text { Characteristics that legal officials interpret } \\
\text { as showing the victim's "good" moral } \\
\text { character and credibility }\end{array}$ & $\begin{array}{l}\mathrm{A} / \mathrm{MA} \\
\mathrm{CY}\end{array}$ & $\begin{array}{l}58 \\
20\end{array}$ & $\begin{array}{l}\text { All studies: elements include the victim did } \\
\text { not engage in risky behavior before the } \\
\text { rape, did not use alcohol or drugs before } \\
\text { the rape, never had consensual inter- } \\
\text { course with the suspect before the rape; } \\
\text { has little sexual experience, no criminal } \\
\text { record, and story is consistent } \\
\text { Child/youth only: relevant for adolescent } \\
\text { victims only }\end{array}$ \\
\hline $\begin{array}{l}\text { Victim's promptness in } \\
\text { reporting }\end{array}$ & $\begin{array}{l}\text { Time between the sexual assault and the } \\
\text { victim's report to the police; delay in re- } \\
\text { porting may give rise to a suspicion that } \\
\text { the victim made up the story; relates } \\
\text { also to victim credibility }\end{array}$ & $\begin{array}{l}\mathrm{A} / \mathrm{MA} \\
\mathrm{CY}\end{array}$ & $\begin{array}{l}42 \\
50\end{array}$ & $\begin{array}{l}\text { All studies: hours between the assault and } \\
\text { report to police or indication of prompt- } \\
\text { ness as reported in studies } \\
\text { Child/youth only: relevant for adolescent } \\
\text { victims only }\end{array}$ \\
\hline
\end{tabular}


Suspect is stranger

Factors relating to the suspect:

Suspect has criminal history

Factors relating to evidence:

Forensic or witness evidence
Relationship between victim and suspect; stranger relation is the main focus for adult victims; literature suggests that stranger cases are more likely to proceed and result in conviction

Suspect's history of arrests or convictions;
suspects known to the police may more suspects known to the police maty
likely be arrested or prosecuted

Elements or persons that corroborate or confirm the victim's story and identify a suspect
A/MA $\quad 88$

CY 90

\section{(e.g., friend, acquaintance, work col-}

Ast known suspect league, family member)

At police stage, suspect is stranger was coded as + or - related to laying charges only when, as far as could be determined, the relationship was not linked to the ability to identify a suspect, but to police decision making to drop or proceed; for comparability, all studies were coded in the same way, regardless of victim age

All studies: previous conviction for sexual or nonsexual offense; or the suspect is known to police, with a previous arrest or having been questioned

A/MA

Adult and mixed age: elements such as forensic evidence of the offender's presence, the presence of semen in the victim's vagina, or a third party witnessing the sexual assault

Child/youth only: see below 
TABLE 10 (Continued)

\begin{tabular}{|c|c|c|c|c|}
\hline \multirow{2}{*}{$\begin{array}{l}\text { Factor } \\
\begin{array}{l}\text { Victim's injury/victim } \\
\text { resistance }\end{array}\end{array}$} & \multirow{2}{*}{$\begin{array}{l}\text { Definition } \\
\text { Evidence such as injury or marks on the } \\
\text { victim's body or verbal expression } \\
\text { (screaming) seen as evidence of victim's } \\
\text { nonconsent }\end{array}$} & \multicolumn{2}{|c|}{$\begin{array}{l}\text { Percent of } \\
\text { Studies with } \\
\text { Factor }^{\mathrm{a}}\end{array}$} & \multirow[b]{2}{*}{$\begin{array}{l}\text { Coding } \\
\text { Adult and mixed age: physical injuries to } \\
\text { the victim, evidence of physical resis- } \\
\text { tance, or verbal expression of } \\
\text { nonconsent } \\
\text { Child/youth only: forensic or witness evi- } \\
\text { dence and victim's injury coded as a sin- } \\
\text { gle factor incorporating all elements be- } \\
\text { cause few studies examined these factors }\end{array}$} \\
\hline & & $\begin{array}{l}\mathrm{A} / \mathrm{MA} \\
\mathrm{CY}\end{array}$ & $\begin{array}{l}88 \\
70\end{array}$ & \\
\hline $\begin{array}{l}\text { Suspect's use of force/ } \\
\text { weapon }\end{array}$ & $\begin{array}{l}\text { Evidence that the suspect forced or threat- } \\
\text { ened the victim into sexual activity, seen } \\
\text { as evidence of victim's nonconsent }\end{array}$ & $\begin{array}{l}\mathrm{A} / \mathrm{MA} \\
\mathrm{CY}\end{array}$ & $\begin{array}{r}67 \\
0\end{array}$ & $\begin{array}{l}\text { Adult and mixed age: suspect used or } \\
\text { threatened to use force or a weapon } \\
\text { against the victim } \\
\text { Child/youth only: factor not studied }\end{array}$ \\
\hline
\end{tabular}

${ }^{a} \mathrm{~A} / \mathrm{MA}=$ adult and mixed age victims $(N=33) ; \mathrm{CY}=$ child/youth victims $(N=10)$. 
cisions made. Initially, we had intended to investigate three decision contexts of police, prosecution, and court. However, most studies did not make precise distinctions between prosecution and court decisions; thus, we combined them as one outcome context. The coding notes on table 10 (col. 3) show decisions made in the analysis and, where relevant, coding decisions in child or youth victim cases.

For the 33 studies of adult and mixed age victims, the most frequently investigated factors are victim-offender relations, victim injury, and victim age (about $80-88$ percent); next is witness or physical evidence, weapon/use of force, and victim character and credibility (about 60-67 percent), followed by promptness in reporting (42 percent) and suspect's criminal history (33 percent; see table 10, col. 2). About half the studies each are from the early and later period. About half are from the United States; Canada and England and Wales each contribute nearly 20 percent and Australia the rest.

2. From Studies to Observations. Because the studies analyze police or prosecution and court decisions, and often both, it is important to distinguish these and to see each as an "observation" from the study. The 33 studies produced a total of 281 observations of positive, negative, or no relationship to the factor: 38 percent from the police stage and 62 percent from prosecution and court. With an analysis of observations as the focus, the number of findings for each factor can be increased. Thus we are better able to examine similarities and differences in the strength and direction of the factors for police and prosecution and court decision making. Each observation was coded according to the direction of the effect: positively, negatively, or no association, with the case proceeding past the police to the prosecutor or convicted in court. Appendix C displays the outcomes of the factors for the 43 studies, with table $\mathrm{C} 1$ for the adult and mixed age studies and table C2 for child or youth studies. A plus (+) indicates a positive correlation; a minus (-), a negative correlation; ellipses (...), no relation; and a dash (--), that the factor was not considered in the study.

3. Effects of Factors on Case Outcomes for Adult and Mixed Age Cases.

Table 11 shows the effects of seven factors for the early and later periods for adult and mixed age victim cases (the victim's age is discussed below, and the victim's sex is considered only in the child/youth studies). In the results for the early period and with both stages combined, the factor evincing the most consistent effect on police and court de- 
TABLE 11

Impact of Each Factor on Police and Court Outcome, by Time Period: Adult and Mixed Age Victims

\begin{tabular}{|c|c|c|c|c|c|c|c|}
\hline \multirow[b]{2}{*}{ Stage } & \multicolumn{7}{|c|}{ Factor } \\
\hline & $\begin{array}{l}\text { Victim's Good } \\
\text { Character and } \\
\text { Credibility (\%) }\end{array}$ & $\begin{array}{c}\text { Victim's } \\
\text { Promptness } \\
\text { in Reporting (\%) }\end{array}$ & $\begin{array}{c}\text { Suspect Is } \\
\text { Stranger (\%) }\end{array}$ & $\begin{array}{c}\text { Suspect's } \\
\text { Criminal History } \\
(\%)\end{array}$ & $\begin{array}{c}\text { Forensic/ } \\
\text { Witness } \\
\text { Evidence (\%) }\end{array}$ & $\begin{array}{c}\text { Victim's } \\
\text { Injury/ } \\
\text { Resistance (\%) }\end{array}$ & $\begin{array}{c}\text { Use of } \\
\text { Force/ } \\
\text { Weapon (\%) }\end{array}$ \\
\hline & \multicolumn{7}{|c|}{ Early Period 1970-89 } \\
\hline All stages & $N=18$ & $N=9$ & $N=21$ & $N=12$ & $N=20$ & $N=24$ & $N=15$ \\
\hline$(+)$ effect & 89 & 33 & 48 & 58 & 45 & 67 & 47 \\
\hline Police & $N=7$ & $N=3$ & $N=8$ & $N=5$ & $N=8$ & $N=10$ & $N=6$ \\
\hline$(+)$ effect & 100 & 33 & 38 & 80 & 13 & 70 & 50 \\
\hline \multirow{3}{*}{$\begin{array}{l}\text { Prosecution/court } \\
(+) \text { effect }\end{array}$} & $N=11$ & $N=6$ & $N=13$ & $N=7$ & $N=12$ & $N=14$ & $N=9$ \\
\hline & 82 & 33 & 54 & 43 & $67^{\mathrm{a}}$ & 64 & 44 \\
\hline & \multicolumn{7}{|c|}{ Later Period, 1990-2005 } \\
\hline All stages & $N=13$ & $N=12$ & $N=28$ & $N=3$ & $N=16$ & $N=25$ & $N=22$ \\
\hline$(+)$ effect & $38^{\mathrm{b}}$ & 33 & $25^{\mathrm{c}}$ & 67 & 50 & 76 & 55 \\
\hline Police & $N=5$ & $N=4$ & $N=12$ & $N=0$ & $N=6$ & $N=10$ & $N=9$ \\
\hline$(+)$ effect & $40^{\mathrm{d}}$ & 25 & 41 & $\ldots$ & 50 & 80 & 67 \\
\hline Prosecution/court & $N=8$ & $N=8$ & $N=16$ & $N=3$ & $N=10$ & $N=15$ & $N=13$ \\
\hline (+) effect & $38^{\mathrm{c}}$ & 38 & $13^{\mathrm{d}, \mathrm{e}}$ & 67 & 50 & 73 & 46 \\
\hline
\end{tabular}

${ }^{a}$ Significantly stronger impact on prosecution/court than on police outcome, $p<.05$.

Significant drop in later period, $p<.01$.

Significant drop in later period, $p<.10$.

'Significant drop in later period, $p<.05$.

${ }^{\mathrm{e}}$ Significantly stronger impact on prosecution/court than on police outcome, $p<.10$. 
cisions is the victim's character and credibility ( 89 percent). Next is the presence of injuries (67 percent) and the suspect's criminal history (58 percent). Close to half of the observations show that stranger relations (48 percent), use of force or weapon (47 percent), and forensic or witness evidence (45 percent) affected legal outcomes. On the basis of the research literature, we might have expected to see an even greater influence of stranger relations in the earlier period, but this dichotomy may fail to capture a range of relationships that affect police and court decisions.

In the later period with police and court and prosecution stages combined, the picture changes significantly for two factors: the influence of victim character and credibility decreases significantly (from 89 to 38 percent), as does stranger relations (from 48 to 25 percent). ${ }^{32}$ Forensic or witness evidence, injury, and weapon factors increase somewhat (by 5-9 percentage points), although the increase is not statistically significant. There are too few studies to analyze country and temporal variation, but we combined Australia, Canada, and England and Wales and then compared their combined results with those for the United States for each time period. The pattern of results is the same for the two groups.

A similar temporal pattern appears when the data are disaggregated by police and court/prosecution decisions. The effect of the victim's character and credibility is strong in the early period for police (100 percent) and prosecution and court ( 82 percent) decisions but drops significantly in the later period for both. The drop in the effects of stranger relations is significant for prosecution and court decisions, but not for police decisions. Just one factor had differential effects for the police compared to prosecution or court: forensic or witness evidence differentiated prosecution and court outcomes, but not those for the police, and only in the early period. In the later period, this factor had a similar influence on police and prosecution/court outcomes. Although not statistically significant, the effect of the forensic or witness evidence at the police stage increases by over 35 percentage points from the early to the later period.

The 33 studies suggest that the real rape construct, as we define it, is more strongly evinced in the earlier period but attenuates somewhat in the later period, with a significant reduction in the effect of a victim's

${ }^{32}$ With small $N$ sizes, we consider relationships significant at the $p<.10$ level. 
character and credibility and stranger relationships on police and prosecution and court decisions. At the same time, the continued strength of the three evidence factors suggests that independent evidence of nonconsent (e.g., a third-party witness, physical injuries, weapon present) and specific kinds of evidence (i.e., marks on the victim's body) are required. Whereas socially constructed notions of "good" and "bad" victims may have relatively less influence in decision making in the more recent period, the legal requirement for physical evidence of nonconsent remains. Across the two time periods, a victim's prompt reporting affects one-third of cases; there are no police/court differences and no change over time. This aspect of victim credibility plays some role in officials' decision making, but not as strongly as other factors. Across the two time periods, the suspect's having a criminal history does affect police and prosecution and court outcomes. This factor receives relatively less attention in the literature, but our study suggests that constructions of "good" and "bad" offenders are also relevant in understanding attrition, with the latter group more likely to be retained in the criminal process or convicted.

Of the 33 studies, 26 analyze the victim's age, and there are 43 observations from police and court decisions. Age is a difficult factor to assess because studies contain victims of varied age ranges, results are reported imprecisely, and the age relationship is itself complex. Of the 43 observations, a substantial minority ( 42 percent) show a positive relationship between younger-aged victims and police proceeding or prosecution and court outcomes. "Younger-aged" includes victims termed simply "younger," "teenagers," and under the ages of 18, 16, and 13. However, in about half the cases $(N=22)$, the victim's age did not differentiate decisions, and for three, the direction of the relationship appeared to be opposite what we expected. ${ }^{33}$

4. Effects of Factors on Case Outcomes for Child or Youth Victims. For the 10 child or youth victim studies, the typical factors analyzed are the age of victim, stranger victim-offender relations, physical evidence, and the victim's sex (see table 10 and app. table C2). Of 13 observations for age, an age threshold can be discerned in five: cases with victims aged 5-10 years are more likely to proceed past the police or be pros-

\footnotetext{
${ }^{33}$ Cases 41 and 43 have positive court outcomes for victims over 6 and 13 years of age. For case 47, a negative sign for police outcomes (not proceeding with the case) is explained by the fact that both victims were under 18 and the offense occurred between peers.
} 
ecuted or convicted than those with younger victims. In two, prosecution or court conviction is more likely when victims are younger (with no age cutoff given), but in six, there is no effect of age. The 10 observations for the victim's sex show no consistent pattern of cases proceeding: there is no effect in five, three show effects for female victims, and two show effects for male victims. Of 12 observations for stranger relations, just one had an effect, with nonstranger cases more likely to be convicted (this is explained by a higher guilty plea rate for intrafamilial offenses). Of 10 observations for forensic or witness evidence, just three were related positively to police and prosecution/court decisions.

Several points can be drawn. First, it is important to distinguish the handling of cases by victim's age. As we expected, for younger victims, the real rape construct is irrelevant: neither the victim's character or credibility nor stranger relations bear on legal outcomes, and the role of forensic or witness evidence is relatively less influential. Second, when there is an effect of victim's age, it is complex. Across all 43 studies, most observations (about 55-60 percent) show no or contrary effects of age; for adult and mixed age samples, effects are evident for those cases with younger victims or younger than 13-18; for child or youth victims, cases with victims older than 5-10 years are more likely to proceed or be convicted. Future research can be improved in these ways: by analyzing the age gap between victim and offender, not just the absolute age of victims and offenders; being mindful of an "age threshold" below which victims may be considered "too young" for police or prosecutors to proceed; and being more precise in describing victims' ages. Third, for adult and mixed age samples, there appears to be a positive development in the more recent period with a reduction in the effect of a victim's character and credibility and stranger victimoffender relations on police and prosecution and court decisions. It is not clear how this finding relates to the significant decline in overall conviction in three countries but stability in two others. The continuing (and increasing) importance of the evidence factors for adult and mixed age samples suggests that independent proof of nonconsent (injuries, another witness, use of weapon) remains important for successful prosecution and conviction of cases. 


\section{Taking Stock of Attrition Research: Questions and Hypotheses Reprised}

This study is the first to review and assess in a systematic fashion three dimensions of rape case attrition in the legal process: estimates of the overall conviction rate, estimates of case attrition at different stages of the legal process, and the factors associated with conviction and attrition. We assembled, analyzed, and harmonized the findings of 75 studies from five common-law countries over three decades. To contextualize and understand variation in conviction and attrition rates by country and over time, we introduced comparative material on the emergence and consolidation of legal reform, victims' reporting patterns from victimization surveys, police statistics on reported rape, and published court data on rape and sexual assault.

Our review is comprehensive and synthetic, but it is prudent to note its limitations. The estimates of conviction and attrition, along with the factors associated with attrition, are not derived from a representative sample of jurisdictions from the five countries. Rather, they come from places that permitted researcher investigation, perhaps places that were proximate to researchers' universities or government departments; and they describe the police and court handling of rape in largely, although not exclusively, urban areas. Thus, our claims about the temporal and country variation in rape case attrition are made from the information available, and the number of cases is not large. The range in the percentages for overall conviction rates and attrition rates at different stages of the legal process should also alert readers that in many jurisdictions, outcomes often stray from the averages. Variation by region, state or province, or local area within countries, including remote and reserve areas of Indigenous and Native peoples (Amnesty International 2007), especially in the United States, Canada, and Australia, is likely to be considerable, but until there are more studies and data available, we are unable to say more than this.

The initial impetus behind this study - to identify the "average rate of conviction" to sexual offenses of those reported to the police-was, in hindsight, naive. As our investigations progressed, we learned why. Conviction estimates and rates of attrition depend on when and where research is conducted, types of offenses, and the age of victims. Average rates may tell us something, but they mask temporal, country, and other sources of variability.

Our study had six questions and four hypotheses. Questions 1-5 
were about the overall rate of conviction for sexual offenses reported to the police and attrition at particular stages of the criminal justice system. Across three decades in five countries, the average overall rate of conviction to any sexual offense is 15 percent and to the original offense, 9 percent. Conviction and attrition rate averages can be misleading, however, because they vary over time and by country.

The overall conviction rate in the earlier period (1970-89) is 18 percent but drops to 12.5 percent in the later period (1990-2005). The United States and Scotland are unique among the five countries in showing no decline, although the number of Scottish cases is small. Of all countries, England and Wales and Canada have the largest decline in conviction rates (14 and 12.5 percentage points, respectively). In Australia, the decline is less dramatic (5.5 percentage points). Changes in countries' overall conviction rates reflect different patterns of case attrition. For England and Wales, there is a large drop in the case flow into court, coupled with a relatively high trial rate; for Canada, there is a slight drop in case flow into court but a large drop in court conviction; and for Australia, there is a decline in court conviction only. In the later period, England and Wales and Australia show a similar pattern of high trial rates (45-51 percent) but low conviction rates at trial (41-46 percent; unfortunately, trial data are lacking for Canada and Scotland). By comparison, in the later period, the United States has a low trial rate, higher conviction at trial, and overall a higher court conviction rate.

Conviction rates are also sensitive to the ages of victims and offense types. Averages across time and country show that child or youth victim cases are more likely to result in conviction than adult victim cases (18.5 percent compared to 12 percent, respectively) and that rape and penetrative offenses are less likely to be convicted than a broader set of sexual offenses (13 percent and 17 percent, respectively).

Hypothesis 1, that there is a decline in conviction rates over time, is confirmed when using aggregated conviction rates, but it does not hold when disaggregated by country. Rates of conviction decreased in England and Wales and Canada and, to a lesser degree, in Australia, but not in the United States. Compared to the earlier period, overall conviction rates are more similar in the later period, ranging from 10 to 14 percent, for four countries (excluding Scotland).

Hypothesis 2, that the early reform countries would have higher overall rates of conviction than the later reform countries, is not con- 
firmed because no consistent pattern emerges. Overall conviction rates for the later period are somewhat higher for two of three early reform countries (the United States and Canada at 14 percent) and lower for one of two later reform countries (England and Wales at 10 percent). However, the hypothesis is not supported with conviction rates for Australia and Scotland.

Hypothesis 3, that England and Wales would show the highest degree of attrition over time, is supported. Unlike other countries, England and Wales has seen an unusually high rate of increase in reported sexual assault to the police from 1996 to the present. We cannot be sure why such increases are occurring, but among other reasons, we suspect that recent, more comprehensive legal reform and victim supports have contributed to more victims coming forward with complaints. The flow into court percentage has dropped from the earlier to the later period (34 to 17 percent), the largest of any country. This may reflect, in part, increased caseload pressure on police resources and organizational routines and, in part, a changing composition of sexual assaults reported to the police in England and Wales.

Of the five jurisdictions studied, just one-England and Walesevinces a clear pattern between increases in the rate of reporting sexual assault to the police, decreases in the flow of cases into court, and decreases in the overall rate of conviction. In Australia, there were increases in rates of reporting sexual assault, with a decrease in the overall conviction rate but no change in the flow of cases into court. The other countries do not evince any of these relationships. In Canada, the reported rate of sexual assault has decreased, and so too has the flow of cases into court and the overall conviction rate. In the United States, the reported rate of rape has decreased, but the overall conviction rate has stayed about the same. In Scotland, which has just three studies, there are some increases in reported sexual assault but no change in conviction rates.

One problem in making sense of these complex relationships is that we are drawing from different levels of aggregation and sources of information, particularly for Canada, Australia, and the United States, for which trends in national rates of reported rape and sexual assault are being compared with those in the specific jurisdictions where attrition studies have been carried out, not a representative sample of jurisdictions by state or province.

Although victimization surveys in the United States, studies in En- 
gland and Wales, and our ministudy show that more "nontraditional" types of rape and sexual assault (i.e., those involving known relations) are being reported to the police from the early 1990s to 2005, a factor that may be associated with decreasing rates of conviction in the later period, our study does not have adequate information to tease out the complexities of this relationship across all countries with certainty. The relationship is not evident for Canada or the United States, where there is a clear decline in reported rape or sexual assault. It is possible, of course, that rates of reported rape and sexual assault can be decreasing while at the same time nontraditional rapes reported to the police are increasing.

For question 6, on the continued relevance of the real rape construct for adult and mixed age victim studies, there is mixed support. The main factors associated with cases proceeding past the police and prosecution and court outcomes in both time periods were evidence related (forensic or witness evidence, victim injury, and weapon present). However, whereas the victim's character and credibility had a strong influence on police and court decisions in the early period, this reduced significantly in the later period. Both this factor and stranger victimoffender relations had relatively less impact on outcomes in the later period. Evidence factors remain important over time; and from this, we may infer that the state's burden of proving nonconsent remains a constant. In both time periods, the suspect's criminal history affected police and prosecutorial and court decisions, but a victim's promptness in reporting the offense was relatively less important.

As expected, the real rape construct has little relevance for child or youth victim cases. It appears that the standard factors used in attrition studies do not adequately differentiate police, prosecutorial, and court decisions in child or youth victim cases. Even factors that might differentiate outcomes (e.g., sex of the victim) were not associated in any consistent way. Future research needs to explore what does matter in police and prosecutor or court decisions in these cases.

We have answered questions about rape case attrition in the criminal justice system, but many more have been raised. We consider just two. Why do patterns of prosecution and conviction in U.S. courts differ from those in England and Wales, Canada, and, to a lesser degree, Australia? What explains decreases in conviction rates in some countries but not in others?

The United States has a longstanding practice of plea bargaining. 
Published court data and our analysis of attrition studies show that U.S. trial rates are lower, conviction rates at trial are higher, and most convictions are secured by guilty pleas; this is especially evident in the more recent period. Some decades ago, Polk (1985) showed that California court practices differed from those in England and Wales in having a lower case flow into court but higher court conviction rates. This approach to prosecution in the United States (which is likely applicable to many offenses, not just to rape) has been a standard organizational practice for as long as courts have been studied in that country. By comparison, England and Wales, Australia, and Canada came to plea bargaining later, as an officially recognized practice.

From the early to the later period in the United States, case flow into court rates did not change, and conviction by plea bargaining increased. There was a drop in the trial rate and an increase in the rate of conviction at trial. By comparison, in England and Wales, case flow into court dropped greatly over time to levels at and below that of the United States, but prosecutorial practices did not adjust. Rather, the standard organizational practice of going to trial continued, despite moderate levels of conviction at trial. Offense composition, in particular, an increasing share of nontraditional rapes, coupled with an increased press of cases on police and court resources, have likely played a role in reducing overall conviction rates in England and Wales. But in addition, compared to the United States, the greater emphasis in British court culture on adjudication and conviction by trial, rather than disposition by plea and sentence bargaining, has likely affected outcomes.

Rather than asking, why did the conviction rate in the United States not decrease over time, we may wonder why it was lower in the 1970s and 1980s compared to other countries. This is difficult to know. The pattern for the United States in the early period is quite similar to that of Australia: a low flow into court rate, a similar rate of court conviction, and a similar rate of cases going to trial and convicted at trial. However, Australia's overall conviction rate is a bit higher in the early period; differences are more apparent in the later period in the court and trial conviction patterns of the two countries. 


\section{What Should Be Done?}

In 2008 we began presenting these findings on conviction and attrition to many people at seminars and conferences. They ask us, what should be done? No one answer satisfies them. For some time, we have been conducting research on innovative justice responses to rape and sexual assault, comparing court and conference (restorative justice) responses to youth sex offending in Australia (e.g., Daly 2006, 2008; Daly and Curtis-Fawley 2006; Bouhours and Daly 2007). We are now examining other contexts of sexual violence (e.g., in postconflict societies). It is clear that an individualized model of prosecution and trial is not relevant or workable in these contexts and that other social mechanisms must be identified. A global perspective is required that considers widely varying contexts of rape and sexual assault; for now, we consider any city in North America, Australia, or the United Kingdom.

First, in working largely within the legal system, the focus of legal reform must shift away from the rape trial and its evidentiary hurdles and toward mechanisms that encourage admissions by offenders (only those who are factually guilty, of course) at a very early stage. This includes, but is not limited to, more sophisticated police interviewing and better plea-bargaining skills of prosecutors and defense attorneys; there may also be a range of positive reasons to make very early admissions (such as no conviction recorded). Legal practitioners must reassess their sources of professional status and success: rather than adversarial trial heroics, greater emphasis could be placed on negotiating skills and acumen (Daly 2008; see also Freiberg 2007). Many people do not like this component because they think it will result in coerced admissions, increasing criminalization, and rising incarceration. That is not what we envisage. Rather, a changed societal context is required in which "sex offenders" are less stigmatized and demonized and in which sexual offending is recognized as being varied in seriousness and not necessarily requiring a criminal law response. Rather than negative and punitive legal mechanisms upon conviction (such as offender registries), more socially inclusive and integrative approaches should be used. Many people do not like this component either, but for other reasons: they believe it may send the "wrong message" that sexual violence is not being taken seriously. Both components are required, however, if a more innovative justice response to sexual violence is to succeed.

Second, and again working within the legal system, victims, offend- 
ers, and others affected by sexual offenses could have greater participation and voice. A variety of sentencing and plea-taking alternatives is possible, but these can be set in motion only after an admission to offending. Restorative justice conferences as a supplement to court sentencing or as a presentence activity, post-guilty plea (Sherman et al. 2005), or part of a guilty plea (Combs 2007) could give victims a greater opportunity to describe the effects of an offense, for offenders to understand that what they did was wrong and harmful, and for others to check and challenge denials of wrongdoing (Daly and CurtisFawley 2006). Again, many people do not like this idea (see, e.g., Cossins 2008). Indeed, with the exception of New Zealand, a pilot project in Arizona, and some jurisdictions in Australia, Belgium, and the United Kingdom, restorative justice conferencing for sexual offenses is not permitted as a sentencing option. When it is used, it is almost exclusively for youth sex offending.

Frohmann and Mertz (1994) identified dual goals of legal reform: "efficacy" (increasing convictions) and "process" (better treatment and understanding of victims). We have proposed ways to improve efficacy (although with an emphasis on admissions more than convictions) and to improve the process with greater victim participation. The third set of proposals considers ways to improve processes for victims outside the criminal justice system or when reported cases are subsequently withdrawn from court adjudication. Less is written about these contexts, which is ironic because it is what the vast majority of victims experience.

There are a variety of circumstances to consider, among them: a victim may want to disclose an offense to someone but not report it to the police; a victim may report a case and there is strong evidence, but the police are unable to locate a suspect; a victim's case may not be strong legally, although the police and prosecutor believe her story. There are many groups in civil society (e.g., rape crisis centers and faith groups) that already facilitate disclosure and assist victims. Their work could be widened to include informal justice activities. For reported cases that are subsequently withdrawn, informal justice activities could be used, such as restorative justice conferences without offenders or other types of meetings that can validate and vindicate a victim's story. Victim advocates now recognize that because "the wishes and needs of victims are often diametrically opposed to the requirements of legal proceedings" (Herman 2005, p. 574), more effective mecha- 
nisms of "social acknowledgment, support, validation from the community, and vindication" (pp. 574, 585) are needed. These may operate as informal justice processes within civil society or within criminal or civil justice, or as formal justice processes that do not rely on a standard criminal justice model of prosecution and trial.

The way forward, then, is identifying a menu of options for victims and offenders within and outside the legal system; having a more inclusive and less demonizing response to sex offending; giving greater attention to the earliest stages of the legal process (or even prior to a legal process) before a suspect's denials harden; allowing greater participation of victims and offenders during plea taking and presentence; and reducing an emphasis on trial heroics and adversarialism by members of the legal profession. We acknowledge Temkin and Krahé's (2008) proposal for further rape law reform and educational campaigns to change attitudes about sexual behavior. Their ideas have merit, but a more radical change agenda is required, with a focus on greater participation, social support, and societal inclusion of offenders, victims, and others affected by sexual offending and victimization. Incremental legal reform will not get us there. 
APPENDIX A

TABLE A1

Studies in the Review, Overall Conviction Rates, and Stages of the Legal System Examined

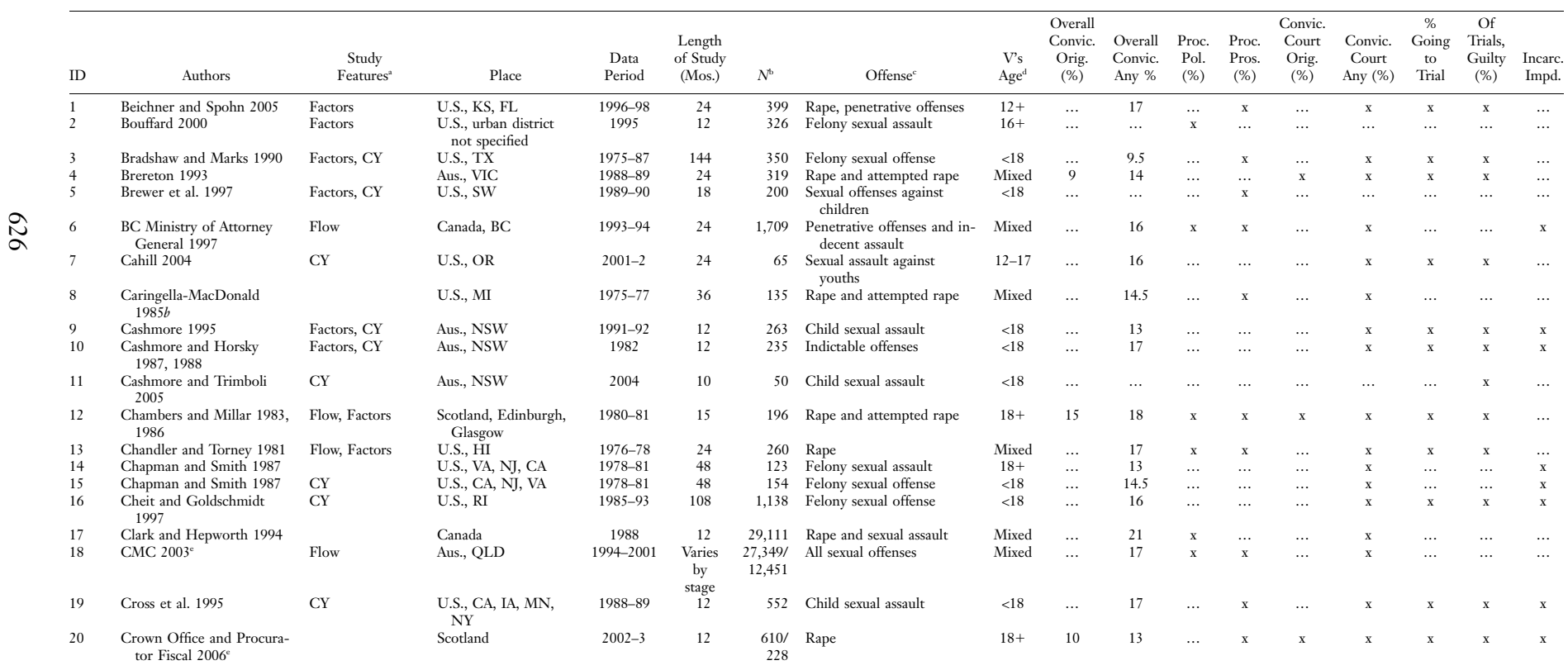




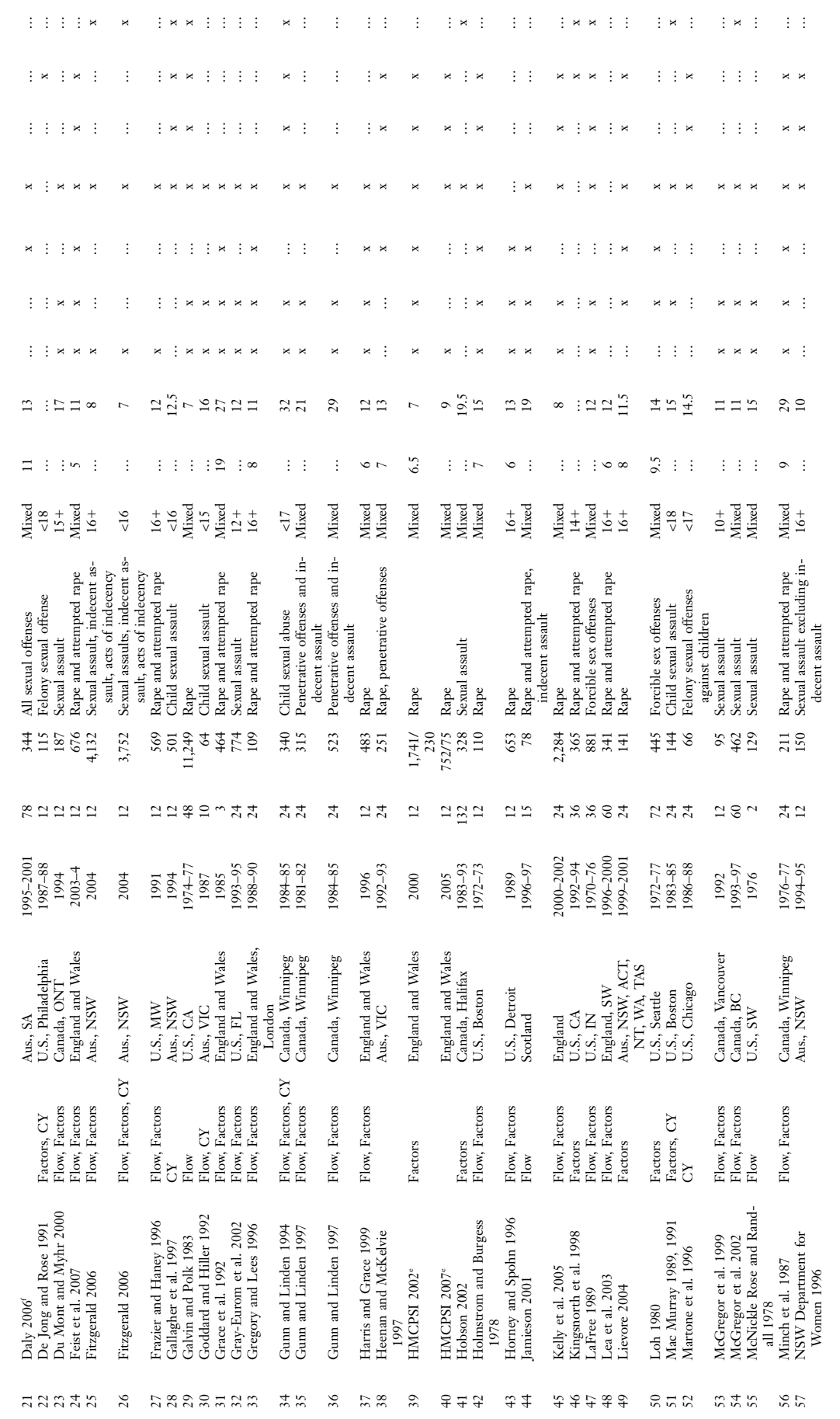

627 
TABLE A1 (Continued)

\begin{tabular}{|c|c|c|c|c|c|c|c|c|c|c|c|c|c|c|c|c|c|}
\hline ID & Authors & $\begin{array}{c}\text { Study } \\
\text { Features }\end{array}$ & Place & $\begin{array}{l}\text { Data } \\
\text { Period }\end{array}$ & $\begin{array}{l}\text { Length } \\
\text { of Study } \\
\text { (Mos.) }\end{array}$ & $N^{b}$ & Offense $^{e}$ & $\begin{array}{c}\mathrm{V}^{\mathrm{s}} \\
\mathrm{Age}^{\mathrm{d}}\end{array}$ & $\begin{array}{c}\text { Overall } \\
\text { Convic. } \\
\text { Orig. } \\
(\%)\end{array}$ & $\begin{array}{l}\text { Overall } \\
\text { Convic. } \\
\text { Any \% }\end{array}$ & $\begin{array}{l}\text { Proc. } \\
\text { Pol. } \\
(\%)\end{array}$ & $\begin{array}{l}\text { Proc. } \\
\text { Pros. } \\
(\%)\end{array}$ & $\begin{array}{c}\text { Convic. } \\
\text { Court } \\
\text { Orig. } \\
(\%)\end{array}$ & $\begin{array}{c}\text { Convic. } \\
\text { Court } \\
\text { Any }(\%)\end{array}$ & $\begin{array}{c}\% \\
\text { Going } \\
\text { to } \\
\text { Trial }\end{array}$ & $\begin{array}{c}\text { Of } \\
\text { Trials, } \\
\text { Guilty } \\
(\%)\end{array}$ & $\begin{array}{l}\text { Incarc. } \\
\text { Impd. }\end{array}$ \\
\hline 58 & Parkinson et al. 2002 & $\mathrm{CY}$ & Aus., Sydney & $1988-90$ & 24 & 163 & Child sexual assault & $5-15$ & 12 & 20 & $\ldots$ & & $\mathrm{x}$ & $\mathrm{x}$ & $\mathrm{x}$ & $\mathrm{x}$ & $x$ \\
\hline & Patterson $2005^{\mathrm{s}}$ & Factors & U.S., MI & 1999-2002 & 3 & 185 & Rape & $18+$ & $\ldots$ & 24 & $\mathrm{x}$ & $\mathrm{x}$ & $\ldots$ & $\mathrm{x}$ & 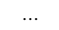 & & $\mathrm{x}$ \\
\hline 60 & Rambow et al. 1992 & Flow, Factors & U.S., Minneapolis & 1983 & 12 & 182 & Sexual assault & $16+$ & $\ldots$ & 10 & $\ldots$ & & $\ldots$ & & $\ldots$ & $\ldots$ & ... \\
\hline 61 & San Lazaro et al. 1996 & Flow, $\mathrm{CY}$ & England, North & & 24 & 154 & Child sexual assa & $<16$ & $\cdots$ & 35 & $\mathrm{x}$ & $\mathrm{x}$ & $\cdots$ & $\mathrm{x}$ & $\cdots$ & $\cdots$ & $\cdots$ \\
\hline $\begin{array}{l}62 \\
63\end{array}$ & $\begin{array}{l}\text { Snodgrass } 2006 \\
\text { Soulles et al. } 1978\end{array}$ & $\begin{array}{l}\begin{array}{l}\text { llow } \\
\text { Flow }\end{array} \\
\text { (a) }\end{array}$ & $\begin{array}{l}\text { U.S., AK } \\
\text { U.S. Denver }\end{array}$ & $\begin{array}{l}2000-2003 \\
1974\end{array}$ & $\begin{array}{c}36 \\
5\end{array}$ & $\begin{array}{r}1,032 \\
99\end{array}$ & $\begin{array}{l}\text { Rape and sexual assault } \\
\text { Rape }\end{array}$ & $\underset{9+}{\text { Mixed }}$ & $\cdots$ & $\begin{array}{c}11 \\
8\end{array}$ & $\mathrm{x}$ & $\mathrm{x}$ & & $\mathrm{x}$ & & & $\cdots$ \\
\hline $\begin{array}{l}63 \\
64\end{array}$ & $\begin{array}{l}\text { Soulesert etal. } \\
\text { Spears and Spohn } 1997\end{array}$ & $\begin{array}{l}\text { Fiow } \\
\text { Factors, CY }\end{array}$ & $\begin{array}{l}\text { U.S., Denver } \\
\text { U., Detroit }\end{array}$ & $\begin{array}{l}1974 \\
1989\end{array}$ & 12 & 132 & $\begin{array}{l}\text { Rape } \\
\text { Child sexual assault }\end{array}$ & $<13$ & $\cdots$ & $\begin{array}{c}8 \\
\ldots\end{array}$ & $\cdots$ & $x$ & $\cdots$ & $\begin{array}{l}x \\
\ldots\end{array}$ & $\cdots$ & $\cdots$ & $\ldots$ \\
\hline 65 & Spohn and Holleran 2001 & Factors & $\begin{array}{l}\text { U.S., Kansas City, } \\
\text { Philadelphia }\end{array}$ & $1996-98$ & 36 & 526 & Rape and sexual assault & $12+$ & $\ldots$ & & & $\mathrm{x}$ & & & & & $\ldots$ \\
\hline 66 & Spohn and Horney & Facto & U.S., Detroit & $1970-$ & 60 & 279 & Rape and sexual assault & Mixed & 13 & 16 & & & $\mathrm{x}$ & $\mathrm{x}$ & & & $\ldots$ \\
\hline 68 & & $\begin{array}{l}\text { Factor } \\
\text { Floww }\end{array}$ & & & 120 & & Rape and sexu & Mixed & 12.5 & 16 & $\ldots$ & $\cdots$ & $\mathrm{x}$ & $\mathrm{x}$ & & & .. \\
\hline $\begin{array}{l}68 \\
69\end{array}$ & $\begin{array}{l}\text { Stroudd et al. } 2000 \\
\text { TTininalli and Hoelzer } 1985\end{array}$ & $\begin{array}{l}\text { Flow, Factors, } \\
\text { Flor }\end{array}$ & $\begin{array}{l}\text { U.S, NM } \\
\text { US, Detroii }\end{array}$ & $\begin{array}{l}1993-96 \\
1980\end{array}$ & 48 & $\begin{array}{c}957 \\
372\end{array}$ & Child sexual assault & $<18$ & $\cdots$ & 18 & $\mathrm{x}$ & 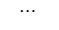 & 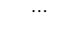 & $\mathrm{x}$ & $\cdots$ & $\mathrm{x}$ & $\cdots$ \\
\hline 70 & 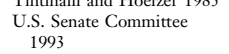 & & $\begin{array}{l}\text { U.S., Detroit } \\
\text { U.S., } 10 \text { states }\end{array}$ & $\begin{array}{l}1980 \\
1990\end{array}$ & $\begin{array}{r}6 \\
12\end{array}$ & $\begin{array}{r}372 \\
7,530\end{array}$ & $\begin{array}{l}\text { Rape } \\
\text { Rape }\end{array}$ & $\begin{array}{l}13+ \\
16+\end{array}$ & $\dddot{m}$ & & $\begin{array}{l}\cdots \\
\cdots \\
\end{array}$ & $\cdots$ & $\cdots$ & $\mathrm{x}$ & $\cdots$ & $\cdots$ & $\dddot{x}$ \\
\hline 71 & $\begin{array}{l}\text { Victorian Law Review } \\
\text { Commission 2001 }\end{array}$ & & Aus., VIC & 1997-99 & 24 & 357 & Rape & Mixed & 6 & 13 & $\cdots$ & $x^{2}$ & $x$ & $\mathrm{x}$ & $\mathrm{x}$ & $\mathrm{x}$ & $\cdots$ \\
\hline 72 & $\begin{array}{l}\text { Victorian Law Review } \\
\text { Commission } 2003\end{array}$ & $\mathrm{CY}$ & Aus., VIC & 1997-99 & 24 & 258 & USI & $<16$ & 9 & 13.5 & $\ldots$ & $\mathrm{x}$ & $\mathrm{x}$ & $\mathrm{x}$ & $\mathrm{x}$ & $\mathrm{x}$ & $\ldots$ \\
\hline $\begin{array}{l}73 \\
74\end{array}$ & $\begin{array}{l}\text { Weninger } 1978 \\
\text { Wiley et al. } 2003\end{array}$ & $\begin{array}{l}\text { Factors } \\
\text { Flow }\end{array}$ & $\begin{array}{l}\text { U.S., TX } \\
\text { U.S., urban }\end{array}$ & $\begin{array}{l}1970-76 \\
1997-99\end{array}$ & $\begin{array}{l}72 \\
33\end{array}$ & $\begin{array}{l}201 \\
888\end{array}$ & $\begin{array}{l}\text { Rape and attempted rape } \\
\text { Sexual assault }\end{array}$ & $\begin{array}{c}\text { Mixed } \\
15+\end{array}$ & $\begin{array}{l}\cdots \\
\cdots\end{array}$ & 13 & $\begin{array}{l}\mathrm{x} \\
\ldots\end{array}$ & $\cdots$ & $\begin{array}{l}\cdots \\
\cdots\end{array}$ & $\cdots$ & $\cdots$ & $\cdots$ & $\begin{array}{l}\cdots \\
\ldots\end{array}$ \\
\hline 75 & Wundersitz 2003 & Flow, $\mathrm{CY}$ & $\begin{array}{r}\text { not sp } \\
\text { Aus., SA }\end{array}$ & 2000-2001 & 12 & 952 & $\begin{array}{l}\text { All sexual offenses against } \\
\text { children }\end{array}$ & $<18$ & $\ldots$ & 13 & $\mathrm{x}$ & $\mathrm{x}$ & $\ldots$ & $\mathrm{x}$ & $\ldots$ & $\ldots$ & $\mathrm{x}$ \\
\hline
\end{tabular}

a This variable lists selected elements of the studies: "flow" indicates that the study reported on overall conviction rate; "factors" that the study examined one or more factors and is listed in app. B; "CY" that the study focuses on child/youth victims (under 18 years) only; if it also includes factors, it is listed in app. table B2.

${ }^{\mathrm{b}}$ Number of cases in the attrition analysis. If the analysis covers the whole legal process, it is the number of cases reported to the police; otherwise, it is the number of cases at the first stage considered.

${ }^{\mathrm{c}}$ This classification is based on the seriousness of the legal charges as reported by the study author(s).

${ }^{\mathrm{d}}$ When the victim's age was not given in the study, we classified victim ages as mixed.

${ }^{\mathrm{e}}$ Study is based on snapshots of the criminal justice system. Figures in the $N$ column are $N$ in police sample/ $N$ in court sample.

${ }^{\mathrm{f}}$ This is the only study that focuses on youth offenders ( $<18$ years) who were dealt with in the Youth Court and by conference.

${ }^{\mathrm{g}}$ This study is not included in the rate analysis because it is an outlier, but it is included in the analysis of factors linked to conviction. 


\section{APPENDIX B}

Estimating Attrition and Conviction

\section{A. Youth Suspects}

For the flow studies, the cases reported to the police included all suspects, regardless of age. In most of these studies, the authors then dropped any youths from subsequent analyses, and appropriately so, because they would be handled in other court jurisdictions. Of the flow studies, 11 reported the number of youths dropped, and we were able to correct the number of suspects at the police stage accordingly. For 19 flow and snapshot studies, however, it was not clear if youth suspects were included or not in the sample; this is a possible source of "false attrition." On the basis of the 11 flow studies with sufficient information, we estimate that the proportion of youth suspects in samples of sexual assault cases reported to the police ranges from 11 to 22 percent (mean, 16 percent). This proportion varies according to the offenses considered: more youth suspects are in studies of child victims than of adult victims.

\section{B. Stages of Attrition and Calculations}

When a victim reports a rape or sexual assault to the police, they may record the complaint but then classify the case as "unfounded" (United States and Canada) or "no crimed" (England and Wales and Scotland) because it is deemed not to be a crime. Attrition at the police stage also occurs when no suspect can be identified, the victim withdraws the complaint, or there is not enough evidence to charge a suspect. After a suspect is arrested and charged, prosecutors may drop the case if they think a conviction is unlikely; or the victim may withdraw because she does not want to go through a trial. Once in court, cases may be dismissed or withdrawn by officials. If the case goes to trial, a judge or jury may find the defendant not guilty. Table B1 shows how attrition and conviction are calculated in this study.

\section{Harmonization}

Harmonization required that we apply our counting and estimation rules systematically across the studies. At times, this meant that we needed to correct estimates made by the study author(s) to ensure that our estimates were accurate and comparable. Here we consider three points about the estimates: police base rates, sites of attrition, and defining conviction.

Police base rates are a crucial starting point in any study because they form the basis for all subsequent calculations of attrition and conviction. Some authors included, but others excluded, cases that the police classified as unfounded or no crimed. When possible, we recalculated a study's conviction rates to include unfounded and no crimed cases in the police base rates. This is conventional practice in attrition research today and for good reason: there is significant temporal and jurisdictional variation in the degree to which cases are deemed unfounded or no crimed (in 1973, 1 percent of rape complaints to the police were deemed unfounded in Detroit and 54 
TABLE B1

Method of Calculating Key Variables

\begin{tabular}{|c|c|}
\hline Percentage of Cases That & Rate \\
\hline Proceed past police $^{a}$ & $\begin{array}{l}N \text { cases referred for prosecution } \div \\
N \text { cases reported to police }\end{array}$ \\
\hline Proceed past prosecution & $\begin{array}{l}N \text { cases in court } \div N \text { cases referred } \\
\text { for prosecution }\end{array}$ \\
\hline Are convicted of any sex offense ${ }^{b}$ & $\begin{array}{l}N \text { convicted of at least one sex of- } \\
\text { fense } \div N \text { cases in court }\end{array}$ \\
\hline Are convicted of original sex offense & $\begin{array}{l}N \text { convicted of original sex offense } \div \\
N \text { cases in court }\end{array}$ \\
\hline Go to trial & $\begin{array}{l}N \text { cases going to trial } \div N \text { cases in } \\
\text { court }\end{array}$ \\
\hline $\begin{array}{l}\text { Are convicted at trial of any sex } \\
\text { offense }\end{array}$ & $\begin{array}{l}N \text { convicted at trial of at least one sex } \\
\text { offense } \div N \text { cases going to trial }\end{array}$ \\
\hline Are sentenced to incarceration ${ }^{c}$ & $\begin{array}{c}N \text { cases with incarceration imposed } \div \\
N \text { cases convicted of any offense }\end{array}$ \\
\hline \multicolumn{2}{|l|}{ For 38 flow studies: } \\
\hline $\begin{array}{l}M_{\text {flow }}=\text { mean overall rate of con- } \\
\text { viction to any sex offense }\end{array}$ & $\begin{array}{l}N \text { convicted of at least one sex of- } \\
\text { fense } \div N \text { cases reported to police }\end{array}$ \\
\hline $\begin{array}{l}M_{\text {flow/orig }}=\text { mean overall rate of } \\
\text { conviction to original sex offense }\end{array}$ & $\begin{array}{l}N \text { convicted of original sex offense } \div \\
N \text { cases reported to police }\end{array}$ \\
\hline
\end{tabular}

a Denominator includes "no crimed" or "unfounded" cases.

${ }^{b}$ In studies with little detail provided, the convicted offense could be a nonsexual offense.

${ }^{\mathrm{c}}$ No study specified whether the incarceration was to serve or was wholly or partially suspended.

percent in Chicago; see Estrich 1987, pp. 15-16). Part of what is occurring is attrition based on police judgments of a complaint's credibility and character.

Attrition at different stages of the legal process is an important point of our investigation, but decision-making sites are not always precise or clear. For example, comparing two U.S. jurisdictions, Spohn and Holleran (2001) noted that in Kansas City, the decision to charge a suspect with sexual assault was made by a specialized prosecution unit, whereas in Philadelphia, the decision was made by the police before the case reached the specialized prosecution unit. Thus, attrition (or retention) in the charging decision occurred in the prosecutor stage in Kansas City but in the police stage in Philadelphia. The attrition estimates for the police and prosecutorial stages, in particular, should be viewed as somewhat rubbery.

\section{Estimating Overall Conviction Rates}

The 38 flow studies provide the most accurate estimate of the overall rate of conviction. However, we augmented the pool of studies by computing 
TABLE B2

Four Steps in Estimating Overall Conviction Rates from 65 Studies

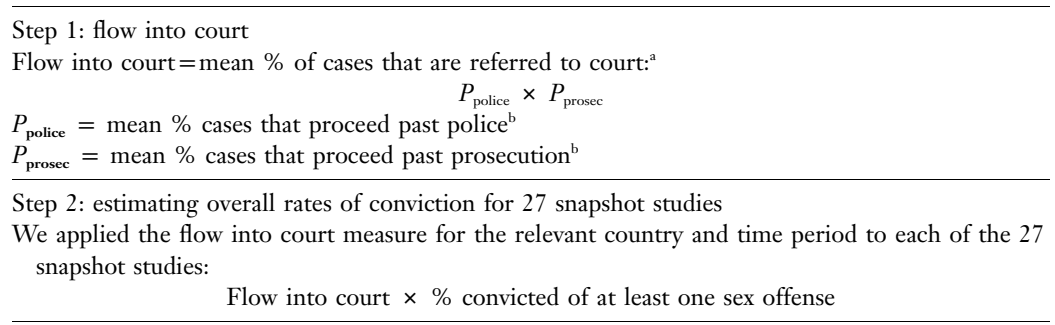

Step 3: estimate from pooled flow and snapshot studies ${ }^{c}$

Mean overall rates of conviction from 38 flow studies and estimates from 27 snapshot studies:

$$
M_{\text {pooled }}=\frac{\text { Doverall rates of conviction from flow studies }+ \text { estimates from snapshot studies }}{65}
$$

Step 4: harmonizing rates from flow studies and estimates from snapshot studies Final overall rate of conviction reported:

$$
\left(M_{\text {flow }}+M_{\text {pooled }}\right) / 2
$$

$M_{\text {flow }}$ : mean overall conviction rate from flow studies only $(N=38$; see table 4$)$

$M_{\text {pooled }}$ : mean overall rate of conviction from pooled flow and snapshot studies $(N=65$; see step 3$)$

NoTE.-Calculations are shown for conviction to any sexual offense; where possible, we calculated conviction to original sexual offense using the same principle and relevant data.

${ }^{\text {a }}$ Each mean is computed from both flow and snapshot studies.

${ }^{\mathrm{b}}$ We calculated the flow into court by country and time period by multiplying $P_{\text {police }}$ and $P_{\text {prosec }}$ for each relevant country and/or time period. Results were as follows: early period: United States, 19.9 percent; Australia, 20.4 percent; Canada, 34.7 percent; England and Wales, 34.1 percent; Scotland, 38 percent; later period: United States, 19.2 percent; Australia, 19.7 percent; Canada, 26.3 percent; England and Wales, 16.8 percent; Scotland, 38 percent.

${ }^{c}$ The $N$ of studies in the nominator and denominator will reduce by country and time period.

estimates of conviction from the 27 snapshot studies that had a rate of court conviction. We did this in four stages as shown in table B2.

In step 1, we constructed a measure of the flow into court, that is, the proportion of cases reported to the police that were referred to court for adjudication. The flow into court measure is the product of two estimates: the mean rate of cases that proceeded past the police and the mean rate of cases that proceeded past prosecution. Drawing from data in the flow and snapshot studies, we calculated the flow into court by country and early or later time period. In step 2, we estimated an overall rate of conviction for each relevant snapshot study by multiplying the flow into court measure with the rate of court conviction. Where possible, we also calculated a rate of conviction to the original sexual offense. In step 3 , we pooled our total of 65 overall rates of conviction to any sexual offense (38 from flow studies and 27 estimated from snapshot studies) and 22 overall rates of conviction to the 
original sexual offense (11 from flow studies and 11 estimated from snapshot studies).

In step 4, we compared the mean overall rate of conviction from the flow studies only $(N=38)$ with the mean overall rate of conviction obtained by pooling results from flow studies and estimates from snapshot studies $(N=$ 65). There was a negligible difference between these two means. However, some discrepancies of less than 2 percentage points arose when we disaggregated the results in smaller groups, such as rates by country and time period. For example, from the flow studies only $(N=9)$, the overall conviction rate for the United States in the early period was 12.2 percent; with the estimate from the pooled flow and snapshot studies $(N=20)$, it was 13.5 percent (a difference of 1.3 percentage points). To solve such discrepancies, the two rates were then averaged to produce the final rates reported in the essay. The rates from the flow studies contribute 75 percent to the final rate average because the flow study rates are more accurate than the estimated snapshot study rates.

We were interested to test the significance of any differences in conviction rates between countries, time periods, age of victims, and types of offense. However, because our final estimated rates of conviction were means of two rates, tests of statistical significance could not be directly computed. We resolved the problem in the following way. First, using analysis of variance, we tested the mean differences for each set of estimates: $(a)$ the rate obtained from 38 flow studies only and $(b)$ the rate obtained from pooling the 65 flow studies and estimates from snapshot studies. We then applied the following rules:

1. If the test was not significant for estimates $a$ and $b$, the difference between the final estimated means was not significant.

2. If the test was significant for both estimates $a$ and $b$, we inferred that the difference between the final estimated means was also significant.

We ran about 50 tests using the two sets of estimates. In almost all cases, there was no discrepancy between estimates $a$ and $b$. However, in four cases, the test was significant at $p<.05$ for estimate $a$ or $b$ but not for both. In these cases, we assessed three factors associated with significance (sample size, size of the effect, and standard deviation) to make a final determination of statistical significance.

\section{E. Study Quality}

Adapting from criteria proposed by Khan et al. (2001), together with an overall quality judgment (Daly and Bordt 1995, p. 174), we created a study quality score with these elements: the study is based on a representative sample, criteria for inclusion are explicit, outcomes are precise and clearly reported, and an overall attrition rate is calculated. Quality scores ranged from 1 to 6 (mean 3.63, standard deviation 1.3); they had a similar distribution across flow and snapshot studies, countries, types of victims, types of offense, and time periods. 
We considered whether additional weights should be applied on the basis of a study's sample size. Samples varied greatly, ranging from 50 to over 29,000 cases. The mean was 426 , the median was 335 , and 85 percent of the studies had samples of fewer than 1,000 cases. Diagnostics showed a curvilinear relationship between study quality and sample size. Lowest-quality studies (scores of 1 and 2) had both high and low sample sizes; highestquality studies (a score of 6 ) had lower sample sizes than the median. Therefore, we could not weight cases on the basis of sample size alone. Khan et al. (2001) suggest applying greater weight to studies with a sample size above the mean sample size. We explored a contingent size-quality weighting approach in which studies meeting a certain threshold (quality score of 4 or higher, sample size greater than 426 cases) were given an additional weight.

Analyses were carried out with the unweighted sample, quality score weighted, and contingent size-quality weighted for the overall conviction rate and estimates at each stage of the legal process. There were nil or negligible differences between the three samples: the mean overall conviction rate was the same, and the percentages proceeding past stages of the justice system differed by no more than 1 percentage point. These results suggest that despite variability in study quality, conviction and attrition rates are robust and stable. Because the quality score added little useful correction to our estimates, we use the unweighted sample in all the analyses. 
APPENDIX C

TABLE C1

Factors Related to Case Outcomes: Adult and Mixed Ages Victims

\begin{tabular}{|c|c|c|c|c|c|c|c|c|c|c|}
\hline ID & Authors & $\begin{array}{c}\text { Stages of } \\
\text { Criminal } \\
\text { Justice } \\
\text { System } \\
\text { Analyzed }\end{array}$ & $\begin{array}{l}\text { Victim's } \\
\text { Age }\end{array}$ & $\begin{array}{c}\text { Victim's } \\
\text { Good } \\
\text { Character } \\
\text { and } \\
\text { Credibility }\end{array}$ & $\begin{array}{c}\text { Victim's } \\
\text { Promptness } \\
\text { in Reporting }\end{array}$ & $\begin{array}{l}\text { Suspect Is } \\
\text { Stranger }^{a}\end{array}$ & $\begin{array}{c}\text { Suspect Has } \\
\text { Criminal } \\
\text { History }\end{array}$ & $\begin{array}{c}\text { Forensic/ } \\
\text { Witness } \\
\text { Evidence }\end{array}$ & $\begin{array}{l}\text { Victim's } \\
\text { Injury/ } \\
\text { Resistance }\end{array}$ & $\begin{array}{c}\text { Suspect's } \\
\text { Use of } \\
\text { Force/ } \\
\text { Weapon }\end{array}$ \\
\hline 1 & Beichner and Spohn 2005 & $\begin{array}{l}\text { Prosecution } \\
\text { Court }\end{array}$ & $\begin{array}{l}+ \text { court } \\
\text { V younger }\end{array}$ & + court & + court & ... court & - & + court & + court & + court \\
\hline 2 & Bouffard 2000 & $\begin{array}{l}\text { Police } \\
\text { Prosecution }\end{array}$ & $\begin{array}{l}\text {... police } \\
\ldots \text { court }\end{array}$ & - & - & $\begin{array}{l}+ \text { police } \\
\ldots \text { court }\end{array}$ & - & - & - & $\begin{array}{l}+ \text { police } \\
\ldots \text { court }\end{array}$ \\
\hline 12 & $\begin{array}{l}\text { Chambers and Millar 1983, } \\
1986\end{array}$ & All & - - & $\begin{array}{l}+ \text { police } \\
+ \text { court }\end{array}$ & - - & - - & $\begin{array}{l}+ \text { police } \\
\ldots \text { court }\end{array}$ & $\begin{array}{l}\text {... police } \\
+ \text { court }\end{array}$ & $\begin{array}{l}+ \text { police } \\
+ \text { court }\end{array}$ & - - \\
\hline 13 & Chandler and Torney 1981 & All & $\begin{array}{l}+ \text { police } \\
+ \text { court } \\
\text { V teen }\end{array}$ & $\begin{array}{l}+ \text { police } \\
+ \text { court }\end{array}$ & - - & $\begin{array}{l}+ \text { police } \\
+ \text { court }\end{array}$ & $\begin{array}{l}+ \text { police } \\
+ \text { court }\end{array}$ & - - & $\begin{array}{l}+ \text { police } \\
+ \text { court }\end{array}$ & $\begin{array}{l}\text { + police } \\
+ \text { court }\end{array}$ \\
\hline 23 & Du Mont and Myhr 2000 & All & $\begin{array}{l}+ \text { police } \\
\mathrm{V} \text { teen } \\
\ldots \text { court }\end{array}$ & $\begin{array}{l}\text {... police } \\
\text {... court }\end{array}$ & $\begin{array}{l}\text {... police } \\
\text {... court }\end{array}$ & $\begin{array}{l}\text { - police } \\
\ldots \text { court }\end{array}$ & - & $\begin{array}{l}+ \text { police } \\
\ldots \text {.. court }\end{array}$ & $\begin{array}{l}+ \text { police } \\
+ \text { court }\end{array}$ & $\begin{array}{l}+ \text { police } \\
+ \text { court }\end{array}$ \\
\hline 24 & Feist et al. 2007 & All & $\begin{array}{l}+ \text { police } \\
+ \text { court } \\
\text { V }<16\end{array}$ & $\begin{array}{l}\ldots \text { police } \\
\ldots \text { court }\end{array}$ & $\begin{array}{l}+ \text { police } \\
+ \text { court } \\
\text { V > } 16\end{array}$ & $\begin{array}{l}\ldots \text { police } \\
\ldots \text { court }\end{array}$ & - & $\begin{array}{l}+ \text { police } \\
+ \text { court } \\
\text { V }>16\end{array}$ & $\begin{array}{l}+ \text { police } \\
+ \text { court } \\
V>16\end{array}$ & -- \\
\hline
\end{tabular}




\begin{tabular}{|c|c|c|c|c|c|c|c|c|c|c|}
\hline 25 & Fitzgerald $2006^{\mathrm{b}}$ & All & $\begin{array}{l}\text {.. police } \\
\text {.. court } \\
+ \text { court } \\
\text { V }<16\end{array}$ & - & - & $\begin{array}{l}\ldots{ }^{*} \text { police } \\
\ldots \text { court }\end{array}$ & - & - & $\begin{array}{l}+ \text { police } \\
\ldots \text { court }\end{array}$ & $\begin{array}{l}+ \text { police } \\
\text {... court }\end{array}$ \\
\hline 27 & Frazier and Haney 1996 & All & -- & $\begin{array}{l}\ldots \text { police } \\
\ldots \text { court }\end{array}$ & - - & $\begin{array}{l}+ \text { police } \\
\ldots \text { court }\end{array}$ & - - & $\begin{array}{l}+ \text { police } \\
\ldots \text { court }\end{array}$ & $\begin{array}{l}+ \text { police } \\
+ \text { court }\end{array}$ & $\begin{array}{l}\ldots \text { police } \\
\ldots \text { court }\end{array}$ \\
\hline 31 & Grace et al. 1992 & All & $\begin{array}{l}+ \text { police } \\
+ \text { court } \\
\text { V }<16\end{array}$ & - & -- & $\begin{array}{l}+ \text { police } \\
+ \text { court }\end{array}$ & $\begin{array}{l}+ \text { police } \\
\ldots \text { court }\end{array}$ & - & $\begin{array}{l}\text { + police } \\
+ \text { court }\end{array}$ & $\begin{array}{l}+ \text { police } \\
+ \text { court }\end{array}$ \\
\hline 32 & Gray-Eurom et al. 2002 & All & $\begin{array}{l}+ \text { police } \\
+ \text { court } \\
\text { V }<18\end{array}$ & -- & - & $\begin{array}{l}\text {.. police } \\
\ldots \text { court }\end{array}$ & -- & $\begin{array}{l}\text {.. police } \\
\text {.. court }\end{array}$ & $\begin{array}{l}\text { + police } \\
+ \text { court }\end{array}$ & $\begin{array}{l}\text { + police } \\
+ \text { court }\end{array}$ \\
\hline 33 & Gregory and Lees 1996 & All & - - & -- & - & $\begin{array}{l}+ \text { police } \\
+ \text { court }\end{array}$ & - - & - - & - - & - - \\
\hline जे & Gunn and Linden 1997 & All & $\begin{array}{l}+ \text { police } \\
\mathrm{V}<18 \\
\ldots \text { c court }\end{array}$ & $\begin{array}{l}+ \text { police } \\
+ \text { court }\end{array}$ & - & $\begin{array}{l}\text {...* police } \\
\text {... court }\end{array}$ & -- & $\begin{array}{l}\text {... police } \\
+ \text { court }\end{array}$ & $\begin{array}{l}\text { + police } \\
+ \text { court }\end{array}$ & $\begin{array}{l}\text {... police } \\
\text {... court }\end{array}$ \\
\hline 36 & Gunn and Linden 1997 & All & $\begin{array}{l}\text {... police } \\
\text {... court }\end{array}$ & $\begin{array}{l}+ \text { police } \\
+ \text { court }\end{array}$ & -- & $\begin{array}{l}\ldots{ }^{*} \text { police } \\
\ldots \text { court }\end{array}$ & -- & $\begin{array}{l}\text {... police } \\
+ \text { court }\end{array}$ & $\begin{array}{l}+ \text { police } \\
+ \text { court }\end{array}$ & $\begin{array}{l}\ldots \text { police } \\
\ldots \text { court }\end{array}$ \\
\hline 37 & Harris and Grace 1999 & All & $\begin{array}{l}+ \text { police } \\
\mathrm{V}<16 \\
+ \text { court } \\
\mathrm{V}<13\end{array}$ & -- & - & $\begin{array}{l}+ \text { police } \\
\ldots \text { court }\end{array}$ & - - & -- & - - & $\begin{array}{l}+ \text { police } \\
\ldots \text { court }\end{array}$ \\
\hline 39 & HMCPSI 2002 & All & $\begin{array}{l}+ \text { court } \\
\mathrm{V}<16\end{array}$ & - & - & - & - & - & ... court & - \\
\hline 41 & Hobson 2002 & Court & $\begin{array}{l}+ \text { court } \\
\mathrm{V}>6\end{array}$ & + court & - - & + court & ... court & - - & - - & - - \\
\hline 42 & Holmstrom and Burgess $1978^{\circ}$ & All & $\begin{array}{l}+ \text { court } \\
\text { V younger }\end{array}$ & + court & + court & + court & - - & + court & + court & - - \\
\hline
\end{tabular}


TABLE C1 (Continued)

\begin{tabular}{|c|c|c|c|c|c|c|c|c|c|c|}
\hline ID & Authors & $\begin{array}{c}\text { Stages of } \\
\text { Criminal } \\
\text { Justice } \\
\text { System } \\
\text { Analyzed }\end{array}$ & $\begin{array}{l}\text { Victim's } \\
\text { Age }\end{array}$ & $\begin{array}{l}\text { Victim's } \\
\text { Good } \\
\text { Character } \\
\text { and } \\
\text { Credibility }\end{array}$ & $\begin{array}{c}\text { Victim's } \\
\text { Promptness } \\
\text { in Reporting }\end{array}$ & $\begin{array}{l}\text { Suspect Is } \\
\text { Stranger }^{\mathrm{a}}\end{array}$ & $\begin{array}{c}\text { Suspect Has } \\
\text { Criminal } \\
\text { History }\end{array}$ & $\begin{array}{c}\text { Forensic/ } \\
\text { Witness } \\
\text { Evidence }\end{array}$ & $\begin{array}{l}\text { Victim's } \\
\text { Injury/ } \\
\text { Resistance }\end{array}$ & $\begin{array}{l}\text { Suspect's } \\
\text { Use of } \\
\text { Force/ } \\
\text { Weapon }\end{array}$ \\
\hline 43 & Horney and Spohn 1996 & All & $\begin{array}{l}\ldots \text { police } \\
\ldots \text { court } \\
+ \text { court } \\
V>13\end{array}$ & $\begin{array}{l}\text {... police } \\
\text {... court }\end{array}$ & $\begin{array}{l}\text {... police } \\
\text {.. court }\end{array}$ & $\begin{array}{l}\text {.. police } \\
\text {.. court }\end{array}$ & $\begin{array}{l}+ \text { police } \\
+ \text { court }\end{array}$ & $\begin{array}{l}\text { + police } \\
+ \text { court }\end{array}$ & $\begin{array}{l}+ \text { police } \\
\ldots \text { court }\end{array}$ & $\begin{array}{l}\text {... police } \\
\text {... court }\end{array}$ \\
\hline 45 & Kelly et al. 2005 & All & $\begin{array}{l}+ \text { court } \\
\mathrm{V}<16\end{array}$ & $\begin{array}{l}+ \text { police } \\
+ \text { court }\end{array}$ & - & $\begin{array}{l}+ \text { police } \\
+ \text { court }\end{array}$ & -- & -- & $\begin{array}{l}\text {... police } \\
+ \text { court }\end{array}$ & $\begin{array}{l}\text {... police } \\
+ \text { court }\end{array}$ \\
\hline 46 & Kingsnorth et al. 1998 & $\begin{array}{l}\text { Prosecution } \\
\text { Court }\end{array}$ & $\begin{array}{l}+ \text { court } \\
\mathrm{V} \text { younger }\end{array}$ & -- & + court & ... court & + court & + court & + court & ... court \\
\hline 47 & LaFree $1989^{d}$ & All & $\begin{array}{l}- \text { police } \\
\mathrm{V}<18\end{array}$ & $\begin{array}{l}+ \text { police } \\
+ \text { court }\end{array}$ & $\begin{array}{l}+ \text { police } \\
+ \text { court }\end{array}$ & $\begin{array}{l}\ldots \text { police } \\
\text {.. court }\end{array}$ & $\begin{array}{l}\text {... police } \\
+ \text { court }\end{array}$ & $\begin{array}{l}\text {... police } \\
+ \text { court }\end{array}$ & $\begin{array}{l}\text {... police } \\
\text {... court }\end{array}$ & $\begin{array}{l}+ \text { police } \\
\ldots \text { court }\end{array}$ \\
\hline 48 & Lea et al. 2003 & All & $\begin{array}{l}\text {... police } \\
\text {... court }\end{array}$ & - & $\begin{array}{l}\ldots \text { police } \\
\text {... court }\end{array}$ & $\begin{array}{l}+ \text { police } \\
- \text { court }\end{array}$ & -- & -- & $\begin{array}{l}\text {... police } \\
\ldots \text { court }\end{array}$ & $\begin{array}{l}\text {... police } \\
\ldots \text { court }\end{array}$ \\
\hline 49 & Lievore 2004 & $\begin{array}{l}\text { Prosecution } \\
\text { Court }\end{array}$ & ... court & ... court & ... court & + court & ... court & + court & + court & + court \\
\hline 50 & Loh 1980 & $\begin{array}{l}\text { Prosecution } \\
\text { Court }\end{array}$ & ... court & + court & ... court & ... court & -- & + court & $\ldots$ court & + court \\
\hline 53 & McGregor et al. 1999 & All & $\begin{array}{l}\text {... police } \\
\text {... court }\end{array}$ & -- & -- & $\begin{array}{l}\ldots{ }^{*} \text { police } \\
\ldots \text { court }\end{array}$ & -- & $\begin{array}{l}\ldots \text { police } \\
\text {... court }\end{array}$ & $\begin{array}{l}+ \text { police } \\
\ldots \text { court }\end{array}$ & $\begin{array}{l}+ \text { police } \\
\ldots \text { court }\end{array}$ \\
\hline 54 & McGregor et al. 2002 & All & $\begin{array}{l}\text {... police } \\
\ldots \text { court }\end{array}$ & -- & - & $\begin{array}{l}- \text { police } \\
\ldots \text { court }\end{array}$ & - - & $\begin{array}{l}\ldots \text { police } \\
\text {... court }\end{array}$ & $\begin{array}{l}+ \text { police } \\
+ \text { court }\end{array}$ & -- \\
\hline 56 & Minch et al. 1987 & All & -- & $\begin{array}{l}+ \text { police } \\
\ldots \text { court }\end{array}$ & $\begin{array}{l}\text {... police } \\
\text {... court }\end{array}$ & - & - & $\begin{array}{l}\text {... police } \\
\text {... court }\end{array}$ & $\begin{array}{l}+ \text { police } \\
\ldots \text { court }\end{array}$ & - \\
\hline
\end{tabular}




\begin{tabular}{|c|c|c|c|c|c|c|c|c|c|c|}
\hline 59 & Patterson 2005 & All & $\begin{array}{l}\ldots \text { police } \\
\ldots \text { court }\end{array}$ & $\begin{array}{l}+ \text { police } \\
\ldots \text { court }\end{array}$ & $\begin{array}{l}\text {... police } \\
\ldots \text { court }\end{array}$ & $\begin{array}{l}\ldots \text { police } \\
\ldots \text { court }\end{array}$ & - - & - - & $\begin{array}{l}+ \text { police } \\
+ \text { court }\end{array}$ & - - \\
\hline 60 & Rambow et al. 1992 & All & - - & - - & - - & - - & - - & $\begin{array}{l}\ldots \text { police } \\
\ldots \text { court }\end{array}$ & $\begin{array}{l}\text {... police } \\
+ \text { court }\end{array}$ & - - \\
\hline 65 & Spohn and Holleran $2001^{\mathrm{e}}$ & Prosecution & ... court & + court & ... court & ... court & + court & + court & + court & + court \\
\hline 66 & Spohn and Horney 1993 & Court & ... court & + court & ... court & ... court & ... court & ... court & ... court & ... court \\
\hline 69 & Tintinalli and Hoelzer 1985 & All & - - & - - & - - & $\begin{array}{l}\text {... police } \\
+ \text { court }\end{array}$ & - - & $\begin{array}{l}\ldots \text { police } \\
\ldots \text { court }\end{array}$ & $\begin{array}{l}\text {... police } \\
+ \text { court }\end{array}$ & - - \\
\hline 73 & Weninger 1978 & Prosecution & - - & - - & - - & + court & - - & + court & + court & + court \\
\hline
\end{tabular}

NOTE.-Dash (- -): factor was not examined in the study. Ellipses (. . .): factor was examined but had no impact on outcome Police: factor positively $(+)$ or negatively $(-)$ related to police charging and referring case for prosecution. Court: factor positively $(+)$ or negatively $(-)$ related to case being prosecuted and/or convicted in court.

${ }^{a}$ Stranger relations was coded positively or negatively for police only for police decision-making process, not for whether a suspect a could be identified. When the study reported a negative effect for stranger relations and police laying charges, but this was due to not being able to identify a suspect, the results are coded as "no effect" and flagged with an asterisk.

${ }^{\mathrm{b}}$ This study analyzed the impact of aggravating factors, which were defined as injuries to the victim, use of force or threats, and/ or presence of weapon.

${ }^{c}$ This study did not report the specific stage of the legal process when the factors had an impact.

In this study police were less likely to lay charges when the victim was under 18 and reported being raped by a male peer.

${ }^{\mathrm{e}}$ Presence of victim's injury was related to charging in partner violence cases; the presence of a weapon was related to prosecutorial charging in stranger cases. 
TABLE C2

Factors Related to Case Outcomes: Child/Youth Victims (under 18 Years)

\begin{tabular}{|c|c|c|c|c|c|c|c|c|c|}
\hline ID & Authors & $\begin{array}{c}\text { Stages of } \\
\text { Criminal } \\
\text { Justice } \\
\text { System } \\
\text { Analyzed }\end{array}$ & $\begin{array}{l}\text { Victim's } \\
\text { Age }\end{array}$ & $\begin{array}{l}\text { Victim's } \\
\text { Sex }\end{array}$ & $\begin{array}{l}\text { Victim's Good } \\
\text { Character and } \\
\text { Credibility }\end{array}$ & $\begin{array}{c}\text { Victim's } \\
\text { Promptness } \\
\text { in Reporting }\end{array}$ & $\begin{array}{l}\text { Suspect Is } \\
\text { Stranger }^{a}\end{array}$ & $\begin{array}{l}\text { Suspect's } \\
\text { Criminal } \\
\text { History }\end{array}$ & $\begin{array}{c}\text { Forensic/ } \\
\text { Witness } \\
\text { Evidence }\end{array}$ \\
\hline 3 & Bradshaw and Marks 1990 & $\begin{array}{l}\text { Prosecution } \\
\text { Court }\end{array}$ & ... court & -- & -- & ... court & ... court & -- & + court \\
\hline 5 & Brewer et al. 1997 & Prosecution & $\begin{array}{l}+ \text { court } \\
\mathrm{V}>8\end{array}$ & $\ldots$ court & -- & + court & $\ldots$ court & -- & -- \\
\hline 9 & Cashmore 1995 & Court & $\begin{array}{l}+ \text { court } \\
\mathrm{V} \text { younger }\end{array}$ & -- & -- & -- & $\ldots$ court & -- & -- \\
\hline 10 & $\begin{array}{l}\text { Cashmore and Horsky } \\
\text { 1987, } 1988\end{array}$ & Court & $\begin{array}{l}+ \text { court } \\
\mathrm{V} \text { younger }\end{array}$ & $\begin{array}{l}+ \text { court } \\
\text { V female }\end{array}$ & -- & -- & $\ldots$ court & $\ldots$ court & ... court \\
\hline 22 & De Jong and Rose 1991 & Court & $\begin{array}{l}+ \text { court } \\
\mathrm{V}>7\end{array}$ & $\ldots$ court & -- & ... court & $\ldots$ court & -- & ... court \\
\hline
\end{tabular}




\begin{tabular}{|c|c|c|c|c|c|c|c|c|c|}
\hline 26 & Fitzgerald 2006 & All & $\begin{array}{l}+ \text { police } \\
V>10 \\
\ldots \text { court }\end{array}$ & $\begin{array}{l}+ \text { police } \\
\text { V female } \\
\text {.. court }\end{array}$ & - & - & $\begin{array}{l}\ldots{ }^{*} \text { police } \\
\ldots \text { court }\end{array}$ & - & $\begin{array}{l}+ \text { police } \\
\ldots \text { court }\end{array}$ \\
\hline 34 & Gunn and Linden 1994 & All & $\begin{array}{l}\ldots \text { police } \\
\ldots \text { court }\end{array}$ & $\begin{array}{l}\text {... police } \\
+ \text { court } \\
\text { V male }\end{array}$ & $\begin{array}{l}+ \text { police } \\
+ \text { court }\end{array}$ & $\begin{array}{l}+ \text { police } \\
\ldots \text { court }\end{array}$ & $\begin{array}{l}\ldots \text { police } \\
\ldots \text { court }\end{array}$ & - & $\begin{array}{l}\text { - police } \\
\text { - court }\end{array}$ \\
\hline 51 & MacMurray 1989, 1991 & $\begin{array}{l}\text { Prosecution } \\
\text { Court }\end{array}$ & $\begin{array}{l}+ \text { court } \\
V>5\end{array}$ & $\begin{array}{l}+ \text { court } \\
\mathrm{V} \text { male }\end{array}$ & - - & - - & - - & - - & - - \\
\hline 64 & Spears and Spohn 1997 & Prosecution & ... court & -- & .. court & ... court & .. court & + court & + court \\
\hline 68 & Stroud et al. 2000 & All & $\begin{array}{l}+ \text { police } \\
V>8 \\
\ldots \text { court }\end{array}$ & $\begin{array}{l}+ \text { police } \\
\text { V female } \\
\ldots \text { court }\end{array}$ & - - & -- & $\begin{array}{l}\ldots \text { police } \\
\text {... court }\end{array}$ & -- & $\begin{array}{l}\ldots \text { police } \\
\ldots \text { court }\end{array}$ \\
\hline
\end{tabular}

${ }^{a}$ Victim and offender were stranger was coded as positively or negatively related to police laying charges only in relation to the police a decision-making process, not in relation to the possibility of identifying a suspect or not. When the study reported a negative effect of stranger relations and police laying charges, but this was due to not being able to identify a suspect, the results are coded as "no effect" and flagged with an asterisk. 
REFERENCES

ABS (Australian Bureau of Statistics). 1994-96. National Crime Statistics, 1993-95. Catalogue no. 4510.0. Canberra: Commonwealth of Australia.

. 1996. Women's Safety Survey 1996. Catalogue no. 4128.0. Canberra: Commonwealth of Australia.

. 2002. Year Book Australia, 2002. Catalogue no. 1301.0. Canberra: Australian Bureau of Statistics.

. 2003. Crime and Safety Australia, 2002. Catalogue no. 4509.0. Canberra: Commonwealth of Australia.

. 2007. Criminal Courts, 2005-06. Catalogue no. 4513.0. Canberra: Australian Bureau of Statistics.

2008. Year Book Australia, 2008. Catalogue no. 1301.0. Canberra: Australian Bureau of Statistics.

AIC (Australian Institute of Criminology). 2008. Australian Crime: Facts and Figures, 2007. Canberra: Australian Institute of Criminology.

Amnesty International. 2007. Maze of Injustice: The Failure to Protect Indigenous Women from Sexual Violence in the USA. New York: Amnesty International USA.

Bargen, Jenny, and Elaine Fishwick. 1995. Sexual Assault Law Reform: A National Perspective. Canberra: Office of the Status of Women.

Baumer, Eric. 2004. Temporal Variation in the Likelibood of Police Notification by Victims of Rapes, 1973-2000. Washington, DC: U.S. Department of Justice, Bureau of Justice Statistics.

Beichner, Dawn, and Cassia Spohn. 2005. "Prosecutorial Charging Decisions in Sexual Assault Cases: Examining the Impact of a Specialized Prosecution Unit." Criminal fustice Policy Review 16:461-98.

Bergen, Raquel K. 2006. Marital Rape: New Research and Directions. Harrisburg, PA: National Online Resource Center on Violence against Women. http:// new.vawnet.org/Assoc_Files_VAWnet/AR_MaritalRapeRevised.pdf.

Bouffard, Jeffrey. 2000. "Predicting Type of Sexual Assault Case Closure from Victim, Suspect, and Case Characteristics." Fournal of Criminal Fustice 28: $527-42$.

Bouhours, Brigitte, and Kathleen Daly. 2007. "Youth Sex Offenders in Court: An Analysis of Judicial Sentencing Remarks." Punishment and Society 9: 371-94.

Bradshaw, Tausha, and Alan E. Marks. 1990. "Beyond a Reasonable Doubt: Factors That Influence the Legal Disposition of Child Sexual Abuse Cases." Crime and Delinquency 36:276-85.

Brereton, David. 1993. "Rape Prosecutions in Victoria." In Women and the Law, Conference Proceedings no. 16, edited by Patricia Easteal and Sandra McKillop. Canberra: Australian Institute of Criminology.

- 1994. "'Real Rape,' Law Reform and the Role of Research: The Evolution of the Victorian Crimes (Rape) Act 1991." Australian and New Zealand Journal of Criminology 27:74-94.

Brewer, Kathleen, Daryl Rowe, and Devon Brewer. 1997. "Factors Related to Prosecution of Child Sexual Abuse Cases." Journal of Child Sexual Abuse 6: 91-111. 
British Columbia Ministry of Attorney General. 1997. Survey of Sexual Assaults Reported to Police in British Columbia, 1993-1994. Vancouver: Police Services Division, BC Ministry of Attorney General.

Brown, Beverley, Michelle Burman, and Lynn Jamieson. 1993. Sex Crimes on Trial: Sexual History and Sexual Character Evidence in Scottish Sexual Offense Trials. Edinburgh: Edinburgh University Press.

Brown, Jennifer, Carys Hamilton, and Darragh O’Neill. 2007. "Characteristics Associated with Rape Attrition and the Role Played by Skepticism or Legal Rationality by Investigators and Prosecutors." Psychology, Crime and Law 13: 355-70.

Bryden, David. 2000. "Redefining Rape." Buffalo Criminal Law Review 3: 317-512.

Bryden, David, and Sonja Lengwick. 1997. "Rape in the Criminal Justice System.” Journal of Criminal Law and Criminology 87:1194-1384.

Bublick, Ellen M. 2006. "Tort Suits Filed by Rape and Sexual Assault Victims in Civil Courts: Lessons for Courts, Classrooms, and Constituencies." Southern Methodist University Law Review 59:55-122.

Bureau of Justice Statistics. 1985. National Crime Surveys: National Sample of Rape Victims, 1973-1982. Washington, DC: U.S. Department of Justice, Bureau of Justice Statistics.

Burman, Michele, Lynn Jamieson, Jan Nicholson, and Oona Brooks. 2007. Impact of Aspects of the Law of Evidence in Sexual Offense Trials: An Evaluation Study. Edinburgh: Scottish Government Social Research.

Cahill, Lesa L. 2004. "Adolescent Sexual Assault: Timing of Physical Exam, Exam Findings, Prior Sexual History, and Legal Outcome.” MS thesis, Gonzaga University, Department of Nursing.

Caringella-MacDonald, Susan. 1985. "Sexual Assault Prosecution: An Examination of Model Rape Legislation in Michigan." In Criminal fustice, Politics, and Women: The Aftermath of Legally Mandated Change, edited by Claudine Schweber and Clarice Feinman. New York: Haworth.

Cashmore, Judy. 1995. "The Prosecution of Child Sexual Assault: A Survey of NSW DPP Solicitors." Australian and New Zealand Fournal of Criminology 28:32-54.

Cashmore, Judy, and Marion Horsky. 1987. Child Sexual Assault: The Court Response. Sydney: NSW Bureau of Crime Statistics and Research, Attorney General's Department.

- 1988. "The Prosecution of Child Sexual Assault." Australian and New Zealand Fournal of Criminology 21:241-52.

Cashmore, Judy, and Lily Trimboli. 2005. An Evaluation of the NSW Child Sexual Assault Specialist Furisdiction Pilot. Sydney: NSW Bureau of Crime Statistics and Research.

Chambers, Gerry, and Ann Millar. 1983. Investigating Sexual Assault. Edinburgh: Scottish Office, Central Research Unit.

- 1986. Prosecuting Sexual Assault. Edinburgh: Scottish Office, Central Research Unit.

Chandler, Susan, and Martha Torney. 1981. "The Decision and the Processing 
of Rape Victims through the Criminal Justice System." California Sociologist 4:155-69.

Chapman, Jane, and Barbara Smith. 1987. "Are Sexual Abusers of Children Treated Differently than Those Who Abuse Adults?" Response 10:17-21.

Cheit, Ross, and Erica Goldschmidt. 1997. "Child Molesters in the Criminal Justice System: A Comprehensive Case-Flow Analysis of the Rhode Island Docket (1985-1993)." New England Fournal on Criminal and Civil Confinement 23:267-302.

Clark, Scott, and Dorothy Hepworth. 1994. "Effects of Reform Legislation on the Processing of Sexual Assault Cases." In Confronting Sexual Assault: A Decade of Legal and Social Change, edited by Julian Roberts and Renate Mohr. Toronto: University of Toronto Press.

Cohen, Thomas, and Brian Reaves. 2006. Felony Defendants in Large Urban Counties, 2002. Washington, DC: U.S. Department of Justice, Bureau of Justice Statistics.

Combs, Nancy. 2007. Guilty Pleas in International Criminal Law: Constructing a Restorative Fustice Approach. Stanford, CA: Stanford University Press.

Cossins, Annie. 2008. "Restorative Justice and Child Sex Offences: The Theory and the Practice." British Fournal of Criminology 48(3):359-78.

Cross, Theodore, Debra Whitcomb, and Edward De Vos. 1995. "Criminal Justice Outcomes of Prosecution of Child Sexual Abuse: A Case Flow Analysis." Child Abuse and Neglect 19:1431-42.

Crown Office and Procurator Fiscal Service (Scotland). 2006. Review of the Investigation and Prosecution of Sexual Offense in Scotland. Edinburgh: Crown Office and Procurator Fiscal Service.

Daly, Kathleen. 2006. "Restorative Justice and Sexual Assault: An Archival Study of Court and Conference Cases." British Fournal of Criminology 46: 334-56.

- 2008. "Setting the Record Straight and a Call for Radical Change: A Reply to Annie Cossins on 'Restorative Justice and Child Sex Offenses."' British Fournal of Criminology 48:557-66.

Daly, Kathleen, and Rebecca Bordt. 1995. "Sex Effects and Sentencing: An Analysis of the Statistical Literature." Fustice Quarterly 12:143-77.

Daly, Kathleen, and Sarah Curtis-Fawley. 2006. "Restorative Justice for Victims of Sexual Assault." In Gender and Crime: Patterns of Victimization and Offending, edited by Karen Heimer and Candace Kruttschnitt. New York: New York University Press.

De Jong, Allan, and Mimi Rose. 1991. "Legal Proof of Child Sexual Abuse in the Absence of Physical Evidence." Pediatrics 88:506-11.

Du Mont, Janice, and Terri L. Myhr. 2000. "So Few Convictions: The Role of Client-Related Characteristics in the Legal Process of Sexual Assaults." Violence against Women 6:1109-36.

Du Mont, Janice, and Deborah White. 2007. The Uses and Impacts of Medicolegal Evidence in Sexual Assault Cases: A Global Review. Geneva: World Health Organization.

Estrich, Susan. 1987. Real Rape. Cambridge, MA: Harvard University Press. 
Farrington, David. 2003. "Methodological Quality Standards for Evaluation Research." Annals of the American Academy of Political and Social Science 587: 49-68.

Feist, Andy, Jane Ashe, Jane Lawrence, Duncan McPhee, and Rachel Wilson. 2007. Investigating and Detecting Recorded Offenses of Rape. London: Home Office.

Finkelhor, David, and Jennifer Dziuba-Leatherman. 1994. "Children as Victims of Violence: A National Survey." Pediatrics 94:413-20.

Finkelhor, David, and Richard Ormrod. 1999. "Reporting Crime against Juveniles." Fuvenile fustice Bulletin (November):1-7.

Finkelhor, David, Janis Wolak, and Lucy Berliner. 2001. "Police Reporting and Professional Help Seeking for Child Crime Victims: A Review." Child Maltreatment 6:17-30.

Fisher, Bonnie, Francis Cullen, and Michael Turner. 2000. The Sexual Victimization of College Women. Washington, DC: U.S. Department of Justice, Office of Justice Programs.

Fitzgerald, Jacqueline. 2006. The Attrition of Sexual Offenses from the New South Wales Criminal Fustice System. Crime and Justice Bulletin no. 92. Sydney: NSW Bureau of Crime Statistics and Research.

Frazier, Patricia, and Beth Haney. 1996. "Sexual Assault Cases in the Legal System: Police, Prosecutor, and Victim Perspectives." Law and Human Behavior 20:607-28.

Freiberg, Arie. 2007. "Non-adversarial Approaches to Criminal Justice." Fournal of Fustice Administration 16:205-22.

Frohmann, Lisa, and Elizabeth Mertz. 1994. "Legal Reform and Social Construction: Violence, Gender, and the Law." Law and Social Inquiry 19:829-51.

Futter, Stacy, and Walter Mebane. 2001. "The Effects of Rape Law Reform on Rape Case Processing." Berkeley Women's Law Journal 16:72-139.

Gallagher, Patricia, Jennifer Hickey, and David Ash. 1997. Child Sexual Assault: An Analysis of Matters Determined in the District Court of New South Wales during 1994. Sydney: Judicial Commission of NSW.

Galvin, Jim, and Kenneth Polk. 1983. "Attrition in Case Processing: Is Rape Unique?" Fournal of Research in Crime and Delinquency 20:126-54.

Garner, Joel, and Christopher Maxwell. 2009. "Prosecution and Conviction Rates for Intimate Partner Violence." Criminal fustice Review 34:44-79.

Gender, Health, and Justice Research Unit. 2008. "Rape Attrition: Understanding Case Withdrawals.” http://www.ghjru.uct.ac.za/projects.htm.

Gilbert, Neil. 1997. "Advocacy Research and Social Policy." In Crime and fustice: A Review of Research, vol. 22, edited by Michael Tonry. Chicago: University of Chicago Press.

Goddard, Chris, and Patricia Hiller. 1992. Tracking Physical and Sexual Abuse Cases from a Hospital Setting into Victoria's Criminal Fustice and Child Protection System, vol. 1. Melbourne: Department of Social Work, Monash University.

Grace, Sharon, Charles Lloyd, and Lorna Smith. 1992. Rape: From Recording to Conviction. London: Home Office.

Gray-Eurom, Kelly, David Seaberg, and Robert Wears. 2002. "The Prosecu- 
tion of Sexual Assault Cases: Correlation with Forensic Evidence." Annals of Emergency Medicine 39:39-46.

Gregory, Jeanne, and Sue Lees. 1996. "Attrition in Rape and Sexual Assault Cases." British Journal of Criminology 36:1-17.

Gunn, Rita, and Rick Linden. 1994. "The Processing of Child Sexual Abuse Cases." In Confronting Sexual Assault: A Decade of Legal and Social Change, edited by Julian Roberts and Renate Mohr. Toronto: University of Toronto Press.

- 1997. "The Impact of Law Reform on the Processing of Sexual Assault Cases." Canadian Review of Sociology and Anthropology 34:155-73.

Hanly, Conor. 2007. "Jury Composition in Rape Cases: Results from the Rape Attrition Project." Paper presented at the Irish Criminology Conference, Dublin, September 5-6.

Harris, Jessica, and Sharon Grace. 1999. A Question of Evidence? Investigating and Prosecuting Rape in the 1990s. London: Home Office.

Heath, Mary. 2005. The Law and Sexual Offenses against Adults in Australia. ACSSA Issues no. 4. Melbourne: Australian Centre for the Study of Sexual Assault, Australian Institute of Family Studies.

Heenan, Melanie, and Helen McKelvie. 1997. The Crimes (Rape) Act 1991: An Evaluation Report. Rape Law Reform Evaluation Project Report no. 2. Melbourne: Attorney-General's Legislation and Policy Branch, Department of Justice.

Heenan, Melanie, and Suellen Murray. 2006. Study of Reported Rapes in Victoria, 2000-2003. Melbourne: Office of Women's Policy, Department for Victorian Communities.

Helweg-Larsen, Karin. 1985. "The Value of the Medico-legal Examination in Sexual Offenses." Forensic Science International 27:145-55.

Herman, Judith. 2005. "Justice from the Victim's Perspective." Violence against Women 11:571-602.

HMCPSI (Her Majesty's Crown Prosecution Service Inspectorate). 2002. A Report on the Foint Inspection into the Investigation and Prosecution of Cases Involving Allegations of Rape. London: Home Office.

- 2007. Without Consent: A Report on the foint Review of the Investigation and Prosecution of Rape Offenses. London: Home Office.

Hobson, Heather. 2002. Second Victimization? The Criminal fustice System's Response to Complainants for Sexual Assault. Halifax, NS: Dalhousie University.

Holmstrom, Lynda, and Ann Burgess. 1978. The Victim of Rape: Institutional Reactions. New York: Wiley.

Home Office. 1989. Criminal Statistics, England and Wales, 1989. London: Home Office.

-1996. Criminal Statistics, England and Wales, 1996. London: Home Office.

Horney, Julie, and Cassia Spohn. 1996. "The Influence of Blame and Believability Factors on the Processing of Simple versus Aggravated Rape Cases." Criminology 34:135-62. 
Irish Rape Attrition Project. 2010. Conor Hanly staff page. http://www .nuigalway.ie/law/staff/conor_hanly.html.

Jamieson, Lynn. 2001. "The Treatment of Women Reporting Sexual Assault by the Scottish Criminal Justice System." Scottish Fournal of Criminal Fustice Studies 7:70-86.

Johnson, Holly. 1996. Dangerous Domains: Violence against Women in Canada. Toronto: Nelson.

Johnson, Holly, Natalia Ollus, and Sami Nevala. 2008. Violence against Women: An International Perspective. New York: Springer.

Johnson, Holly, and Vincent Sacco. 1995. "Researching Violence against Women: Statistics Canada's National Survey." Canadian Journal of Criminology 37:281-304.

Kalven, Harry, and Hans Zeisel. 1966. The American fury. Boston: Little, Brown.

Kelly, Liz. 1988. Surviving Sexual Violence. Minneapolis: University of Minnesota Press.

- 2000. "A War of Attrition." Trouble and Strife 40:9-16.

. 2001. Routes to (In)justice: A Research Review on the Reporting, Investigation and Prosecution of Rape Cases. London: Home Office. http://www .hmcpsi.gov.uk/documents/services/reports/THM/Rapelitrev.pdf.

Kelly, Liz, Jo Lovett, and Linda Regan. 2005. A Gap or a Chasm? Attrition in Reported Rape Cases. London: Home Office.

Kelly, Liz, and Linda Regan. 2001. Rape: The Forgotten Issue? London: Child and Women Abuse Studies Unit.

Kerstetter, Wayne. 1990. "Gateway to Justice: Police and Prosecutorial Response to Sexual Assaults against Women." Fournal of Criminal Law and Criminology 81:267-313.

Khan, Khalid, Gerben ter Riet, Jennie Popay, John Nixon, and Jos Kleijnen. 2001. "Stage II Conducting the Review: Phase 5 Study Quality Assessment." In Undertaking Systematic Reviews of Research on Effectiveness, edited by Khalid Khan, Gerben ter Riet, Julie Glanville, Amanda Sowden, and Jos Kleijnen. York: Centre for Reviews and Dissemination.

Kilpatrick, Dean, and Benjamin Saunders. 1997. Prevalence and Consequences of Child Victimization: Results from the National Survey of Adolescents. Washington, DC: U.S. Department of Justice, Bureau of Justice Statistics.

Kingsnorth, Rodney, John Lopez, Jennifer Wentworth, and Debra Cummings. 1998. "Adult Sexual Assault: The Role of Racial/Ethnic Composition in Prosecution and Sentencing." Journal of Criminal fustice 26:359-71.

Kong, Rebecca. 1997. "Canadian Crime Statistics, 1996.” furistat 17:1-22.

Kong, Rebecca, Holly Johnson, Sara Beattie, and Andrea Cardillo. 2003. "Sexual Offences in Canada." Juristat 23:1-22.

Koss, Mary. 2006. "Restoring Rape Survivors: Justice, Advocacy, and a Call to Action." Annals of the New York Academy of Sciences 1087:206-34.

Koss, Mary, and Christine Gidycz. 1985. "The Sexual Experiences Survey: Reliability and Validity." Fournal of Consulting and Clinical Psychology 53: 442-43. 
Koss, Mary, Christine Gidycz, and Nadine Wisniewski. 1987. "The Scope of Rape: Incidence and Prevalence of Sexual Aggression and Victimization in a National Sample of Higher Education Students." Fournal of Counseling and Clinical Psychology 55:162-70.

LaFree, Gary. 1989. Rape and Criminal fustice: The Social Construction of Rape. Belmont, CA: Wadsworth.

Lea, Susan, Ursula Lanvers, and Steve Shaw. 2003. "Attrition in Rape Cases: Developing a Profile and Identifying Relevant Factors." British fournal of Criminology 43:583-99.

Lievore, Denise. 2003. Non-reporting and Hidden Recording of Sexual Assault: An International Literature Review. Canberra: Office of the Status of Women, Commonwealth of Australia.

2004. Prosecutorial Decisions in Adult Sexual Assault Cases: An Australian

Study. Canberra: Office of the Status of Women, Commonwealth of Australia.

Loh, Wallace. 1980. "The Impact of Common Law and Reform Rape Statutes on Prosecution: An Empirical Study." Washington Law Review 55:543-62.

Lovett, Jo, and Liz Kelly. 2009. Different Systems, Similar Outcomes? Tracking Attrition in Reported Rape Cases across Europe. Final Research Report. London: Child and Woman Abuse Studies Unit, London Metropolitan University.

MacMurray, Bruce. 1989. "Criminal Determination for Child Sexual Abuse: Prosecutor Case-Screening Judgments." Journal of Interpersonal Violence 4: 233-44.

1991. "Legal Responses of Prosecutors to Child Sexual Assault: A Case Comparison of Two Counties." In Abused and Battered: Social and Legal Responses to Family Violence, edited by Dean Knudsen and JoAnn Miller. New York: Aldine de Gruyter.

Martone, Mary, Paula Jaudes, and Mark Cavins. 1996. "Criminal Prosecution of Child Sexual Abuse Cases." Child Abuse and Neglect 20:457-64.

McCahill, Thomas, Linda Meyer, and Arthur Fischman. 1979. The Aftermath of Rape. Lexington, MA: Lexington.

McGregor, Margaret, Janice Du Mont, and Terri Myhr. 2002. "Sexual Assault Forensic Medical Examination: Is Evidence Related to Successful Prosecution?" Annals of Emergency Medicine 39(6):639-47.

McGregor, Margaret, Grace Le, Stephen Marion, and Ellen Weibe. 1999. "Examination for Sexual Assault: Is the Documentation of Physical Injury Associated with the Laying of Charges? A Retrospective Cohort Study." Canadian Medical Association Fournal 160:1565-69.

McMillan, Lesley, and Michelle Thomas. 2008. "Understanding Attrition in Rape Cases: Overview and Preliminary Findings." Paper presented at the eighth annual conference of the European Society of Criminology, Edinburgh, September 4.

McNickle Rose, Vicki, and Susan Randall. 1978. "Where Have All the Rapists Gone? An Illustration of the Attrition-of-Justice Phenomenon.” In Violent Crime: Historical and Contemporary Issues, edited by James Inciardi and Anne Pottieger. Beverly Hills, CA: Sage. 
Minch, Candice, Rick Linden, and Stuart Johnson. 1987. "Attrition in the Processing of Rape." Canadian Fournal of Criminology 29:389-404.

Morris, Allison, and James Reilly. 2003. The New Zealand National Survey of Crime Victims, 2001. Wellington: Ministry of Justice.

Mouzos, Jenny, and Toni Makkai. 2004. Women's Experiences of Male Violence: Findings from the Australian Component of the International Violence against Women Survey (IVAWS). Canberra: Australian Institute of Criminology.

Myers, Martha, and Gary LaFree. 1982. "Sexual Assault and Its Prosecution: A Comparison with Other Crimes." Fournal of Criminal Law and Criminology 73:1282-1305.

Myhill, Andy, and Jonathan Allen. 2002. Rape and Sexual Assault of Women: Findings from the British Crime Survey. London: Research, Development and Statistics Directorate, Home Office.

National Statistics Online (UK). 2008. Population: National, 1971 Onwards. London: Office for National Statistics. http://www.statistics.gov.uk/statbase/ ssdataset.asp? vlnk $=9542 \&$ More $=$ Y.

NSW Bureau of Crime Statistics and Research. 2007. Sexual Violence Information Sheet. Sydney: Attorney-General's Department of NSW.

NSW Criminal Justice Sexual Offences Taskforce. 2005. Responding to Sexual Assault: The Way Forward. Sydney: Attorney General's Department of NSW.

NSW Department for Women. 1996. Heroines of Fortitude: The Experiences of Women in Court as Victims of Sexual Assault. Woolloomooloom, NSW: Department for Women.

NSW Legislative Council, Standing Committee on Law and Justice, ed. 2002. Report on Child Sexual Assault Prosecutions. Sydney: NSW Parliament.

Office for Criminal Justice Reform. 2006. Criminal Statistics 2005, England and Wales. London: Home Office.

Office for National Statistics. 1997. "Population: National." Population Trends 90:51.

Office of Crime Statistics and Research. 2002-6. Crime and Fustice in South Australia, Adult Courts and Corrections. Adelaide: South Australian AttorneyGeneral's Department.

Parkinson, Patrick, Sandra Shrimpton, Heather Swanston, Brian O’Toole, and Kim Oates. 2002. "The Process of Attrition in Child Sexual Assault Cases: A Case Flow Analysis of Criminal Investigations and Prosecutions." Australian and New Zealand Fournal of Criminology 35:347-62.

Patterson, Debra. 2005. "The Legal Prosecution of Adult Rape Cases Processed by a Sexual Assault Nurse Examiner Program." MA thesis, Michigan State University, Department of Psychology.

Pentillä, A., and P. J. Karhumen. 1990. "Medicolegal Findings among Rape Victims." Medical Law 9:725-37.

Polk, Kenneth. 1985. "A Comparative Analysis of Attrition of Rape Cases." British fournal of Criminology 25:280-84.

Queensland Crime and Misconduct Commission. 2003. Seeking Fustice: An Inquiry into the Handling of Sexual Offenses by the Criminal Fustice System. Brisbane: Crime and Misconduct Commission. 
Rambow, Beth, Cher Adkinson, Thomas H. Frost, and Garry F. Peterson. 1992. "Female Sexual Assault: Medical and Legal Implications." Annals of Emergency Medicine 21:727-31.

Regan, Linda, and Liz Kelly. 2003. Rape: Still a Forgotten Issue. London: Child and Woman Abuse Studies Unit.

Rennison, Callie. 2002. Rape and Sexual Assault: Reporting to Police and Medical Attention, 1992-2000. Washington, DC: U.S. Department of Justice, Bureau of Justice Statistics.

Roberts, Julian. 1996. "Sexual Assault in Canada: Recent Statistical Trends." Queen's Law Fournal 21:395-421.

Roberts, Julian, and Robert Gebotys. 1992. "Reforming Rape Laws: Effect of Legislative Change in Canada." Law and Human Behavior 16:555-73.

Russell, Diana. 1975. The Politics of Rape: The Victim's Perspective. New York: Stein \& Day.

San Lazaro, Camille, Alison M. Steele, and Liam J. Donaldson. 1996. "Outcome of Criminal Investigation into Allegations of Sexual Abuse." Archives of Disease in Childhood 75:149-52.

Savoie, Jose. 2002. "Crime Statistics in Canada, 2001." Furistat 22:1-22.

Schulhofer, Stephen. 1998. Unwanted Sex: The Culture of Intimidation and the Failure of the Law. Cambridge, MA: Harvard University Press.

Scottish Executive. 1998. Recorded Crime in Scotland, 1997. Edinburgh: Scottish Executive.

- 2007a. Criminal Proceedings in Scottish Courts, 2005/06. Edinburgh: Scottish Executive.

- 2007b. Recorded Crime in Scotland, 2006-07. Edinburgh: Scottish Executive.

Seidman, Ilene, and Susan Vickers. 2005. "The Second Wave: An Agenda for the Next Thirty Years of Rape Law Reform." Suffolk University Law Review 38:457-90.

Sherman, Lawrence, Heather Strang, Caroline Angel, Daniel Woods, Geoffrey Barnes, Sarah Bennett, and Nova Inkpen. 2005. "Effects of Face-to-Face Restorative Justice on Victims of Crime in Four Randomized, Controlled Trials." Fournal of Experimental Criminology 1:367-95.

Sian, Nicholas, Chris Kershaw, and Allison Walker, eds. 2007. Crime in England and Wales, 2006/07. London: Home Office.

Silver, Warren. 2007. “Canadian Crime Statistics, 1996.” Juristat 27:1-15.

Smart, Carol. 1989. Feminism and the Power of Law. London: Routledge.

Snodgrass, Matthew. 2006. "Sexual Assault Case Processing: A Descriptive Model of Attrition and Decision Making." Alaska fustice Forum 23:4-8.

Snyder, Howard. 2000. Sexual Assault of Young Children as Reported to Law Enforcement: Victim, Incident, and Offender Characteristics. Washington, DC: U.S. Department of Justice, Bureau of Justice Statistics.

Soules, Michael, Stephen Stewart, K. M. Brown, and Albert Pollard. 1978. "The Spectrum of Alleged Rape." Journal of Reproductive Medicine 20:33-39.

South Australian Legislative Review Committee. 2005. Inquiry into Sexual Assault Conviction Rates. Adelaide: South Australia Parliament. 
Spears, Jeffrey, and Cassia Spohn. 1996. "The Genuine Victim and Prosecutors' Charging Decisions in Sexual Assault Cases." American fournal of Criminal fustice 20:183-206.

—. 1997. "The Effect of Evidence Factors and Victim Characteristics on Prosecutors' Charging Decisions in Sexual Assault Cases.” Justice Quarterly 14:501-24.

Spohn, Cassia, and David Holleran. 2001. "Prosecuting Sexual Assault: A Comparison of Charging Decisions in Sexual Assault Cases Involving Strangers, Acquaintances, and Intimate Partners." Fustice Quarterly 18: 651-88.

Spohn, Cassia, and Julie Horney. 1992. Rape Law Reform: A Grassroots Revolution and Its Impact. New York: Plenum.

. 1993. "Rape Law Reform and the Effect of Victim Characteristics on Case Processing." Journal of Quantitative Criminology 9:383-409.

Statistics Canada. 2007. Cases in Adult Criminal Court, by Province and Territory. Ottawa: Statistics Canada.

Stroud, Delores, Sonja Martens, and Julia Barker. 2000. “Criminal Investigation of Child Sexual Abuse: A Comparison of Cases Referred to the Prosecutor to Those Not Referred." Child Abuse and Neglect 24:689-700.

Sustainability Report. 2008. "Canada's Population, 1861-2050.” York: Institute for Research and Innovation in Sustainability. http://www.sustreport.org/ signals/Cdn_population.xls.

Tang, Kwong-leung. 1998. "Rape Law Reform in Canada: The Success and Limits of Legislation." International Fournal of Offender Therapy and Comparative Criminology 42(3):258-70.

Temkin, Jennifer. 2002. Rape and the Legal Process. Oxford: Oxford University Press.

Temkin, Jennifer, and Barbara Krahé. 2008. Sexual Assault and the fustice Gap: A Question of Attitude. Oxford: Hart.

Tintinalli, Judith, and Marion Hoelzer. 1985. "Clinical Findings and Legal Resolution in Sexual Assault." Annals of Emergency Medicine 14:447-53.

Tjaden, Patricia, and Nancy Thoennes. 2006. Extent, Nature, and Consequences of Rape Victimization: Findings from the National Violence against Women Survey. Washington, DC: U.S. Department of Justice, Office of Justice Programs.

Triggs, Sue, Elaine Mossman, Jan Jordan, and Venezia Kingi. 2009. Responding to Sexual Violence: Attrition in the New Zealand Criminal Justice System. Wellington: Ministry of Women's Affairs.

U.S. Senate Judiciary Committee. 1993. The Response to Rape: Detours on the Road to Equal Fustice. Washington, DC: U.S. Senate.

Van Kesteren, John, Pat Mayhew, and Paul Nieuwbeerta. 2000. Criminal Victimisation in Seventeen Industrialised Countries: Key Findings from the 2000 International Crime Victims Survey. The Hague: Ministry of Justice, WODC.

Victorian Law Reform Commission. 2001. "Sexual Offences: Law and Procedure.” Discussion paper. Melbourne: Victorian Law Reform Commission. 
2003. Sexual Offences: Interim Report. Melbourne: Victorian Law Reform Commission.

Walker, Allison, Chris Kershaw, and Nicholas Sian, eds. 2006. Crime in England and Wales, 2005/06. London: Home Office.

Walker, John. 1994. Trends in Crime and Criminal Justice. In The Australian Criminal 7ustice System: The Mid-1990s, edited by Duncan Chappell and Paul Wilson. Melbourne: Butterworths.

WAVAW (Women Against Violence Against Women). 2005. "Rape Statistics." http://www.wavaw.ca/informed_stats.php.

Weninger, Robert A. 1978. "Factors Affecting the Prosecution of Rape: A Case Study of Travis County, Texas.” Virginia Law Review 64:357-97.

Wiley, Jennifer, Naomi Sugar, David Fine, and Linda Eckert. 2003. "Legal Outcomes of Sexual Assault." American Fournal of Obstetrics and Gynecology 188:1638-41.

Williams, Joyce. 1984. "Secondary Victimization: Confronting Public Attitudes about Rape." Victimology 9:66-81.

Wundersitz, Joyce. 2003. Child Victims of Sexual Offences: Tracking from Police Incident Report to Finalisation in Court. Briefing paper. Adelaide: Office of Crime Statistics and Research. 